Division of Geological \& Geophysical Surveys

PRELIMINARY INTERPRETIVE REPORT 2009-5

\title{
GEOLOGY OF THE COBBLESTONE CREEK-MAY CREEK AREA, EAST-CENTRAL BROOKS RANGE FOOTHILLS, ALASKA
}

by

Charles G. Mull, Ellen E. Harris,

Paige R. Delaney, and Robert F. Swenson

June 2009

Released by

STATE OF ALASKA

DEPARTMENT OF NATURAL RESOURCES

Division of Geological \& Geophysical Surveys 3354 College Rd.

Fairbanks, Alaska 99709-3707 



\section{CONTENTS}

\section{Geology of the Cobblestone Creek-May Creek area, east-central Brooks Range foothills, Alaska}

by Charles G. Mull, Ellen E. Harris, Paige R. Delaney, and Robert F. Swenson

Introduction

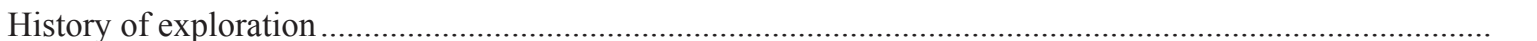

Acknowledgments.

General geology and structural evolution of the Cobblestone Creek-May Creek area............................... 3

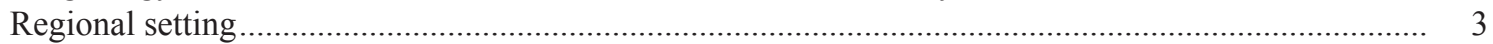

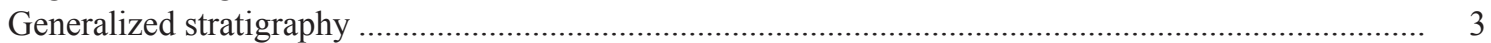

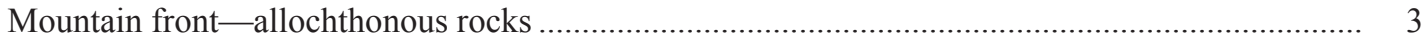

Disturbed belt — allochthonous rocks .............................................................................. 6

Disturbed belt — parautochthonous rocks .......................................................................

Disturbed belt —Cobblestone parautochthonous sequence .................................................. 8

Foothills foldbelt — foreland basin deposits ......................................................................... 9

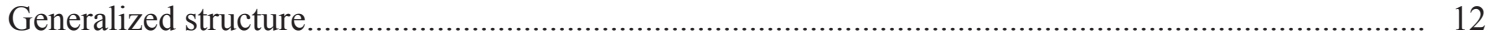

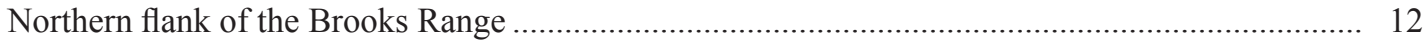

Endicott Mountains allochthon ................................................................................... 12

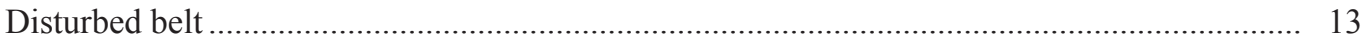

Picnic Creek or Ipnavik River allochthon ..................................................................... 13

Mélange/olistostrome belt ......................................................................................... 13

Cobblestone parautochthonous sequence .......................................................................... 13

Triangle zone ....................................................................................................... 14

Foothills foldbelt ........................................................................................ 14

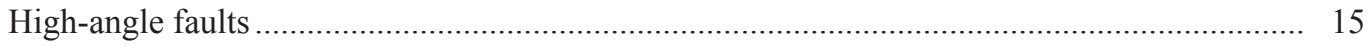

Summary of structural history................................................................................. 16

Depositional and structural evolution of the Cobblestone Creek-May Creek area ...................... 16

Hydrocarbon source rock potential and thermal maturity anomalies .............................................. 17

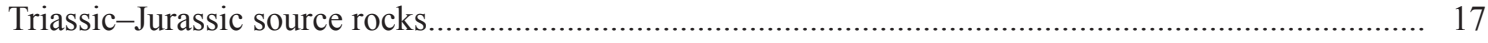

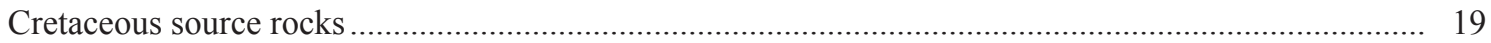

Preliminary apatite fission-track data from the Cobblestone Creek-May Creek area by Paul B. O’Sullivan

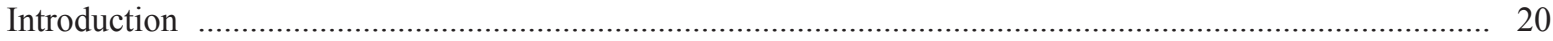

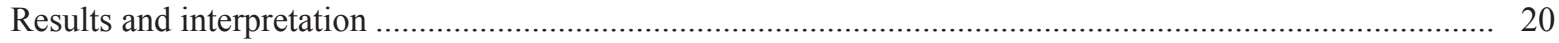

Endicott Mountains allochthon at mountain front................................................................. 20

Disturbed belt_—Picnic Creek or Ipnavik River allochthon ........................................................... 20

Disturbed belt — Unnamed mélange/olistostrome ..................................................................... 21

Disturbed Belt —Cobblestone parautochthonous sequence .......................................................... 22

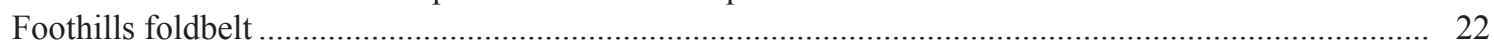

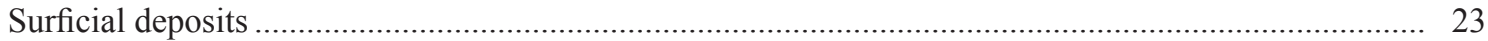

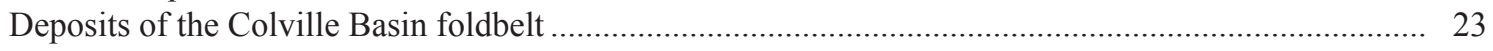

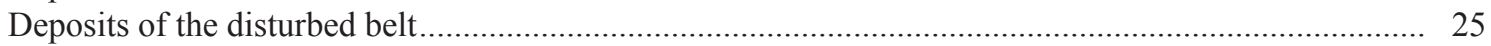

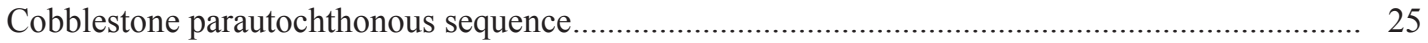

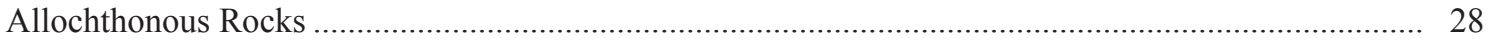

Syntectonic turbidites, mélange, and olistostromal deposits .............................................. 28

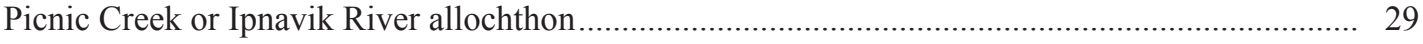

Deposits of the Brooks Range Mountain front....................................................................... 29

Endicott Mountains allochthon .................................................................................... 29

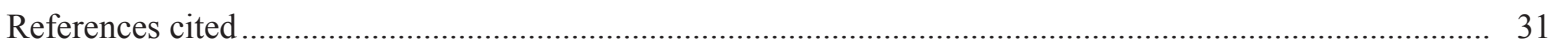




\section{FIGURES}

Figure 1. Generalized geologic map and index map of Cobblestone Creek-May Creek area, central Brooks Range foothills

2. Diagrammatic section showing generalized stratigraphy and structure of Colville Basin .....

3. View westward along Endicott Mountains front at Cobblestone Creek, showing frontal thrust fault in Lisburne Group carbonates and overturned exposures of Siksikpuk and Otuk Formations in west bank of Cobblestone Creek

4. View eastward along Endicott Mountains front at Nanushuk Lake showing two thrust sheets of Lisburne Group limestone and dolomite.

5. Structurally contorted Otuk Formation on east side of the west fork of May Creek at Endicott Mountains front.

6. View of blocks of Buchia limestone coquina in sheared black shale groundmass of mélange of southern mélange/olistostrome belt along east fork of May Creek just north of mountain front... 8

7. View of a structurally complicated bluff on east side of Cobblestone Creek

8. View eastward of unnamed phosphatic-manganiferous shale on north side of Cobblestone ridges near western tributary of Cobblestone Creek.

9. Eastward view of Cobblestone ridges west of Cobblestone Creek showing tightly folded beds of Cobblestone Member of Fortress Mountain Formation in axis of tight anticlinal fold deformed by overlying thrust sheet of Cobblestone Member and Torok Formation

10. View west along crest of Cobblestone ridges east of May Creek showing north-vergent, thrustimbricated sheets of Cobblestone Member of Fortress Mountain Formation

11. View east to north-dipping lower Nanushuk Formation on Tuktu Escarpment at Cobblestone Creek

12. View east to Arc Mountain anticline at Nanushuk River

13. Diagram showing correlation of various thermal maturation indices for organic material, and zones of petroleum generation and destruction

14. Cross section $\mathrm{A}-\mathrm{A}^{\prime}$ ' showing generalized apatite fission-track data across structural belts in Cobblestone Creek-May Creek area

\section{APPENDIX}

Figure A1. Station location map for analytical samples, appendix tables A1 and A2 ......

Table A1. Selected micropaleontology and organic geochemical data from Cobblestone Creek-May Creek area

A2 Apatite fission-track data from Cobblestone Creek-May Creek area 39

\section{SHEET}

(in envelope)

Geologic map of the Cobblestone Creek-May Creek area, east-central Brooks Range Foothills, Alaska 


\title{
GEOLOGY OF THE COBBLESTONE CREEK-MAY CREEK AREA, EAST-CENTRAL BROOKS RANGE FOOTHILLS, ALASKA
}

\author{
by \\ Charles G. Mull ${ }^{1}$, Ellen E. Harris ${ }^{2}$, Paige R. Delaney ${ }^{3}$, and Robert F. Swenson ${ }^{3}$
}

\section{INTRODUCTION}

The Cobblestone Creek-May Creek area of the foothills of the Endicott Mountains is one of a series of areas selected for detailed mapping to document important structural and stratigraphic relationships at the mountain front of the east-central Brooks Range. The Cobblestone Creek-May Creek map area is important in delineating the stratigraphic and structural relationships in this region because, unlike the adjacent valleys of the Itkillik and Nanushuk rivers, Cobblestone and May creeks were not glaciated during the Pleistocene, and thus bedrock exposures are generally more continuous. Local field studies by the Alaska Division of Geological \& Geophysical Surveys (DGGS) began in the area in 1982 and continued intermittently in conjunction with other field studies. In recent years, interest in hydrocarbon exploration in the Brooks Range foothills has increased considerably, resulting in an opportunity to compile previous studies as well as to carry out additional field studies to address specific structural and stratigraphic problems. In addition, ongoing mapping and structural and stratigraphic studies in the Siksikpuk River-Tiglukpuk Creek area to the west (Peapples and others, 2007) have resulted in some revised structural and stratigraphic concepts that have proven to be applicable to the Cobblestone Creek-May Creek map area and the adjacent Kanayut River map area to the west (Harris and others, 2009).

\section{HISTORY OF EXPLORATION}

Reconnaissance bedrock geologic mapping and stratigraphic studies in the Cobblestone Creek-May Creek map area were first carried out by E.J. Webber and R.L. Detterman of the U.S. Geological Survey (USGS) in 1947 as part of a USGS program to evaluate and explore the Naval Petroleum Reserve \#4 (Pet 4). In mid May 1947, Webber and Detterman were flown by ski plane to a snow-covered river bar on the Nanushuk River just upstream from the mouth of May Creek. From there they explored upstream on foot, delineated the major structures now known as Arc Mountain syncline, Arc Mountain anticline, and May Creek syncline. On the south flank of Arc Mountain anticline, they measured and described a stratigraphic section of what is now known as the Nanushuk Formation (Albian-Cenomanian; Webber and Detterman, 1947). For several weeks after spring breakup in early June, they floated and lined a collapsible canvas-covered boat down the Nanushuk River to its mouth, and described for the first time the Upper Cretaceous stratigraphy of this portion of the foothills belt. In particular, they mapped the locations of several of the major anticlines in the northern foothills belt and, at May Creek syncline, noted the excellent porosity and permeability and reservoir quality of the sandstone and conglomerate in what is now known as the Tuluvak Formation.

The first studies of the Carboniferous Lisburne Group, which forms the mountain front, were conducted in 1949 by A.L. Bowsher and J.T. Dutro, Jr., who mapped an outlier of the Lisburne Group north of the mountain front at Nanushuk Lake (Bowsher and Dutro, 1949). The pre-Nanushuk rocks elsewhere in the southern foothills part of the map area were first examined in 1950 by W.W. Patton and A.E. Keller, who mapped the mountain-front structure in the Lisburne Group, and traversed the Nanushuk River and May, Cobblestone, and Peregrine creeks. They also began to delineate some of the basic stratigraphy and structural style of the structurally complicated disturbed belt of Lower Cretaceous to Upper Triassic rocks that occur from the mountain front north to the outcrop belt of the Nanushuk Formation (Patton and Keller, 1950, 1951). A generalized geologic map and cross section in the 1951 report provided a general framework and a starting point for all subsequent mapping in the Cobblestone Creek-May Creek area.

These studies, in combination with USGS field studies elsewhere in the Brooks Range foothills, delineated the regional stratigraphic and structural framework of the east-central Brooks Range mountain front and northern foothills. Reconnaissance bedrock mapping in the Cobblestone Creek-May Creek area was compiled and published

\footnotetext{
${ }^{1}$ Alaska Division of Geological \& Geophysical Surveys, 3354 College Rd., Fairbanks, Alaska 99709-3707; currently Consulting Geologist, Santa Fe, New Mexico.

${ }^{2}$ Alaska Division of Geological \& Geophysical Surveys, 3354 College Rd., Fairbanks, Alaska 99709-3707; currently Consulting Geologist, Ignacio, Colorado.

${ }^{3}$ Alaska Division of Geological \& Geophysical Surveys, 3354 College Rd., Fairbanks, Alaska 99709-3707.
} 
as part of the geologic map of the Killik-Itkillik area by Patton and Tailleur (1964). These published USGS maps and subsequent unpublished reconnaissance mapping by Pessel and Mull (1964) and Sonneman and Mull (1972), which were based in part on the previously published USGS mapping, provided a starting point for the more detailed mapping and stratigraphic studies that are presented here. Other published mapping in the area includes bedrock mapping by Kelley $(1984,1988,1989)$, and mapping of Quaternary deposits by Hamilton (1979). In addition to the studies cited above, the central Brooks Range foothills have been the focus of geologic mapping by a number of oil companies over the years, but little of this work has been released to the public. Reflection seismic surveys also have been carried out in the northern part of the map area, and resulted in Chevron USA drilling Cobblestone $\# 1$, a deep wildcat well, in 1972. Cobblestone \#1 is the only exploratory well in the area. However, neither the results of this well nor data from the seismic surveys has been released to the public.

\section{ACKNOWLEDGMENTS}

We would like to acknowledge the contributions of the pioneering geologists of the U.S. Geological Survey, who established the framework understanding of the stratigraphy and structure of northern Alaska that we have used as the starting point for our more detailed mapping and stratigraphic studies. At one time or another, Irv Tailleur, Bill Brosgé, Tom Dutro, Marv Mangus, Hill Reiser, Bob Detterman, Bill Patton, and Bob Chapman have shared some of their vast reservoir of information on the geology of northern Alaska. In addition to the individuals who contributed directly to the mapping in this area (acknowledged above), discussions with a great number of other colleagues over the years have contributed to our knowledge and understanding of the geology of Alaska's Arctic Slope and northern Brooks Range. Special thanks go to field companions Gar Pessel of Richfield Oil Corporation; Howard Sonneman, Dietrich Roeder, and Gary Newman of Exxon Company USA (now ExxonMobil); Marv Mangus, Kris Meisling, and Tom Eggert of Atlantic Richfield Company/ARCO Alaska (now ConocoPhillips, Inc.); John Decker and John Dillon of DGGS; Irv Tailleur, Inyo Ellersieck, Chuck Mayfield, Karen Kelley, Tom Moore, Dave Houseknecht, Chris Schenk, and Chris Potter of the U.S. Geological Survey; and Keith Crowder, Keith Watts, Wes Wallace, Karen Adams, Dirk Bodnar, Jerry Siok, Richard Glenn, and Marwan Wartes of the University of Alaska Department of Geology and Geophysics. In recent years, we have benefited from discussions with, and geological input in the field from Greg Wilson of ARCO Alaska (now ConocoPhillips, Inc.); Dick Garrard, (now with FEX, Inc.); Paul Decker and Bob Swenson of Conoco Phillips, Inc. (now with DGGS); John Van Fleet, Greg Hebertson, and Jennifer Burton of Anadarko Petroleum; Tom Homza of BP Alaska (now with Shell Oil); and Dave Hite, consultant. Office discussions and reviews by Ken Bird, K. Molenaar, Julie Dumoulin, Sue Karl, and Anita Harris of the USGS have contributed additional data and understanding of the Brooks Range foothills belt. In addition, we acknowledge the paleontological contributions of Mike Mickey and Hideyo Haga of Micropaleo Consultants, and Norm Silberling, Will Elder, and Robert Blodgett (consultant, formerly USGS). Wally Dow and John Allen of Baseline DGSI, Inc., have provided valuable organic geochemical analyses, and Paul O'Sullivan and John Murphy have contributed data and their knowledge of fission-track dating.

None of our field observations in this map area would have been possible without helicopter pilots such as Joe Nightingale and Les Wunsch of Era Helicopters, Mose Carr of Snake River Helicopters, Ken Butters of TransAlaska Helicopters, and others, all of whom spent many hours flying us to and picking us up from remote locations under frequently difficult conditions, and participated in our remote camp lifestyle. Fixed-wing aircraft pilots Irv Kurtz, Frank Whaley, Jr., and others ferried personnel and supplies to our remote field camps in the east-central Brooks Range and Arctic Slope on wheels, skis, or floats and also participated in our camp life.

We are also indebted to the management personnel of Richfield Oil Corporation, Atlantic Richfield Company, Exxon Company USA, the U.S. Geological Survey, Alaska Division of Geological \& Geophysical Surveys, and Alaska Division of Oil and Gas, who provided both the encouragement and financial support to carry out wideranging research projects in areas and at times in which the tangible benefits may have seemed obscure.

Completion of the mapping in the Cobblestone Creek-May Creek area would not have been possible without the support in recent years by a consortium of public and private organizations that have provided funding for field logistics and analytical services. These include the U.S. Geological Survey, Alaska Division of Oil and Gas, U.S. Bureau of Land Management, Arctic Slope Regional Corporation, North Slope Borough, ARCO Alaska (now part of ConocoPhillips, Inc), Anadarko Petroleum, EnCana Corp., BP Alaska, Chevron USA (now ChevronTexaco), Exxon Co. USA (now ExxonMobil, Inc.), Phillips Petroleum (now part of ConocoPhillips, Inc.), PetroCanada, and Alfred James, III. 


\section{GENERAL GEOLOGY AND STRUCTURAL EVOLUTION OF THE COBBLESTONE CREEK-MAY CREEK AREA}

REGIONAL SETTING

The Cobblestone Creek-May Creek area extends northward from the northern flank of the eastern Endicott Mountains across a structurally disturbed belt in the foothills and into the southern part of the Colville basin, a Cretaceous to Tertiary foreland basin that lies north of the Brooks Range orogenic belt (figs. 1 and 2). The Colville basin overlies a regionally south-dipping section of Mississippian to earliest Cretaceous (Lower Neocomian) platform strata of the autochthonous North Slope sequence of the Arctic Alaska plate. These strata are coeval with rocks exposed in thrust sheets that form the northern part of the mountains at the southern edge of the map area. The regional setting of the eastern Arctic Slope and east-central and northeastern Brooks Range are illustrated diagrammatically by Mull and others (1987), and are discussed in Moore and others (1994) and in references contained therein. Following are generalized discussions of the stratigraphy and structure of the Cobblestone Creek-May Creek map area. Detailed descriptions of the stratigraphic units are found in Description of Rock Units later in this report.

\section{GENERALIZED STRATIGRAPHY}

The bedrock exposures in the Cobblestone Creek-May Creek area can be divided into three major structurally bounded belts or domains. From south to north these are: (1) the northern mountain front of the Brooks Range, (2) the "disturbed belt," and (3) the foothills foldbelt in the southern flank of the Colville basin (cross section A-A'). The generalized description of the stratigraphy is given within the framework of these structurally bounded domains.

\section{Mountain front-allochthonous rocks}

The oldest rocks exposed in the map area consist of the Endicott Mountains allochthon, which is composed of, in ascending order, the Lower Mississippian Kayak Shale and Lower Pennsylvanian to Mississippian Lisburne Group. The Kayak Shale primarily consists of incompetent fissile black shale, and it commonly forms a basal detachment surface for many of the thrust sheets within the allochthon that forms the northern flank of the mountains (figs. 1 and 2). These thrust sheets consist of thick, competent limestone and dolomite of the Lisburne Group at the southern edge of the map area. (figs. 3 and 4). In the map area, dolomites in the Lisburne commonly have pinpoint to small vugular porosity that is commonly filled with solid black hydrocarbon. These beds may constitute a potential hydrocarbon exploration objective in the subsurface north of the mountain front.

At the stratigraphic top of the Endicott Mountains allochthon, the Lisburne Group is overlain by a thin section of gray to black silty shale of the Permian Siksikpuk Formation, and by the lower Upper Jurassic to Upper Triassic Otuk Formation, which consists of interbedded organic-rich limestone and black shale and constitutes an excellent hydrocarbon source rock horizon (fig. 5). Overlying the Otuk Formation are the Lower Cretaceous (Valanginian) Kingak Formation and an important marker unit consisting of thin beds of a distinctive limestone coquina informally called "the coquinoid limestone." The coquinoid limestone is generally less than $6.6 \mathrm{ft}(2 \mathrm{~m})$ thick and is composed entirely of the Early Cretaceous (Valanginian) pelecypod Buchia sublaevis (Jones and Grantz, 1965). The unit is a characteristic marker unit for the Endicott Mountains allochthon, and was not deposited on any of the structurally higher allochthons in the Brooks Range.

The Permian to Lower Cretaceous rocks are relatively incompetent, and most are very poorly exposed along the mountain front. No outcrops of the Kingak Shale are found at the mountain front, but it is exposed in the disturbed belt to the north. Although it is very thin, the coquinoid limestone unit is present locally as tectonic slivers at the mountain front and is commonly found as isolated outcrops elsewhere along the entire northern flank of the Endicott Mountains. It is also present in the northwestern DeLong Mountains of the western Brooks Range $360 \mathrm{mi}(575 \mathrm{~km})$ west of the Cobblestone Creek-May Creek area, and locally on the parautochthonous North Slope sequence in the Bathtub Ridge area of the northeastern Brooks Range, $200 \mathrm{mi}(325 \mathrm{~km})$ northeast of the Cobblestone Creek area.

Consistent with their incompetent nature, these rocks acted as detachment horizons along which overlying allochthonous rocks were emplaced. Collectively, the allochthonous Permian to Mississippian rocks constitute the Ellesmerian sequence (Lerand, 1973) and the Valanginian to Triassic rocks are the distal southern equivalents of the Beaufortian sequence (Hubbard and others, 1987). The Ellesmerian sequence was deposited on a stable platform that flanked a cratonic area to the north (present coordinates), whereas the rocks of the Beaufortian sequence are related to incipient and ultimately successful rifting of the stable platform of the Arctic Alaska plate near the present Beaufort Sea coastline. North of the mountain front, autochthonous portions of the Ellesmerian and Beaufortian sequences form the substratum for the Brookian rocks of the southern Colville basin. 


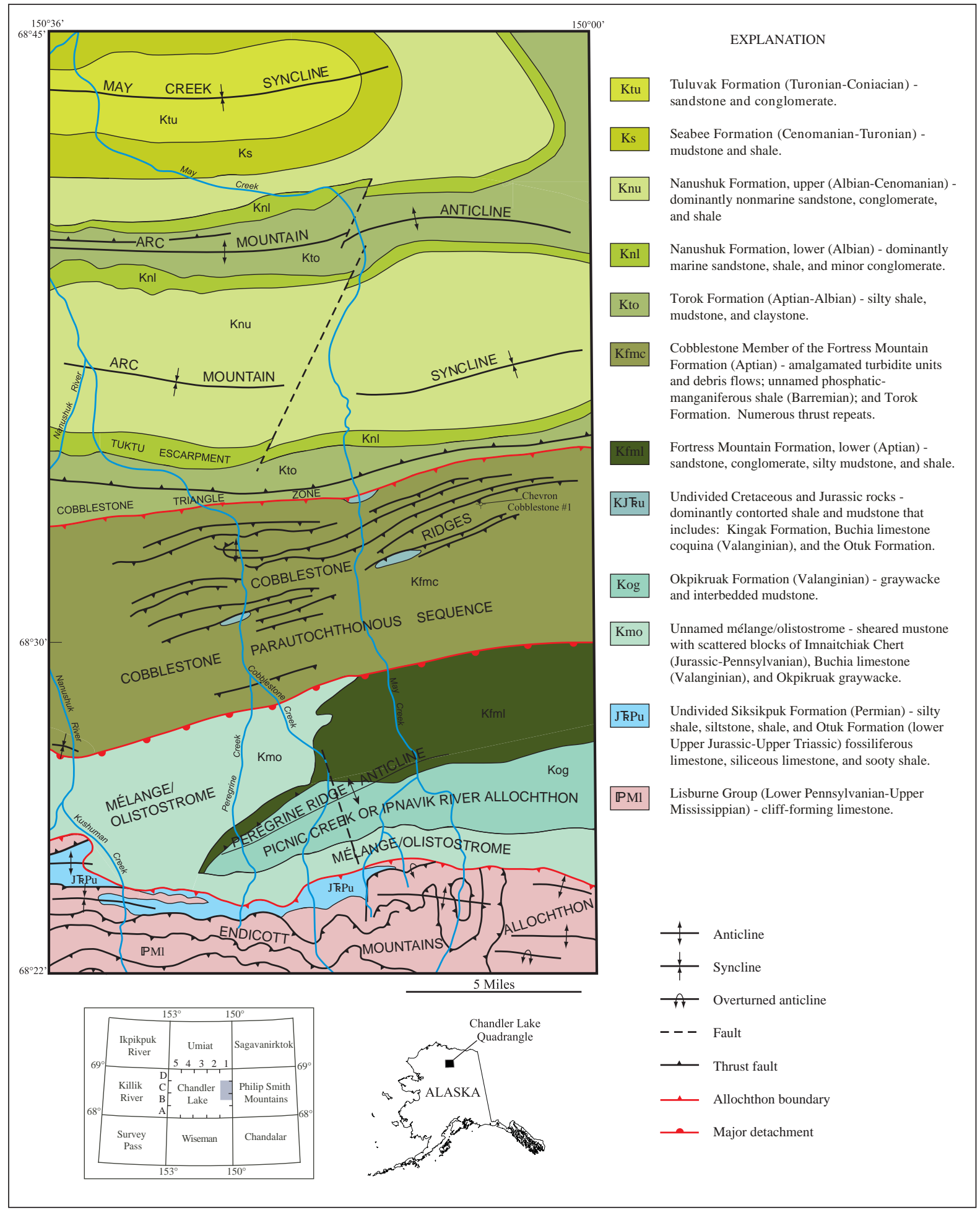

Figure 1. Generalized geologic map and index map of Cobblestone Creek-May Creek area, central Brooks Range foothills. 


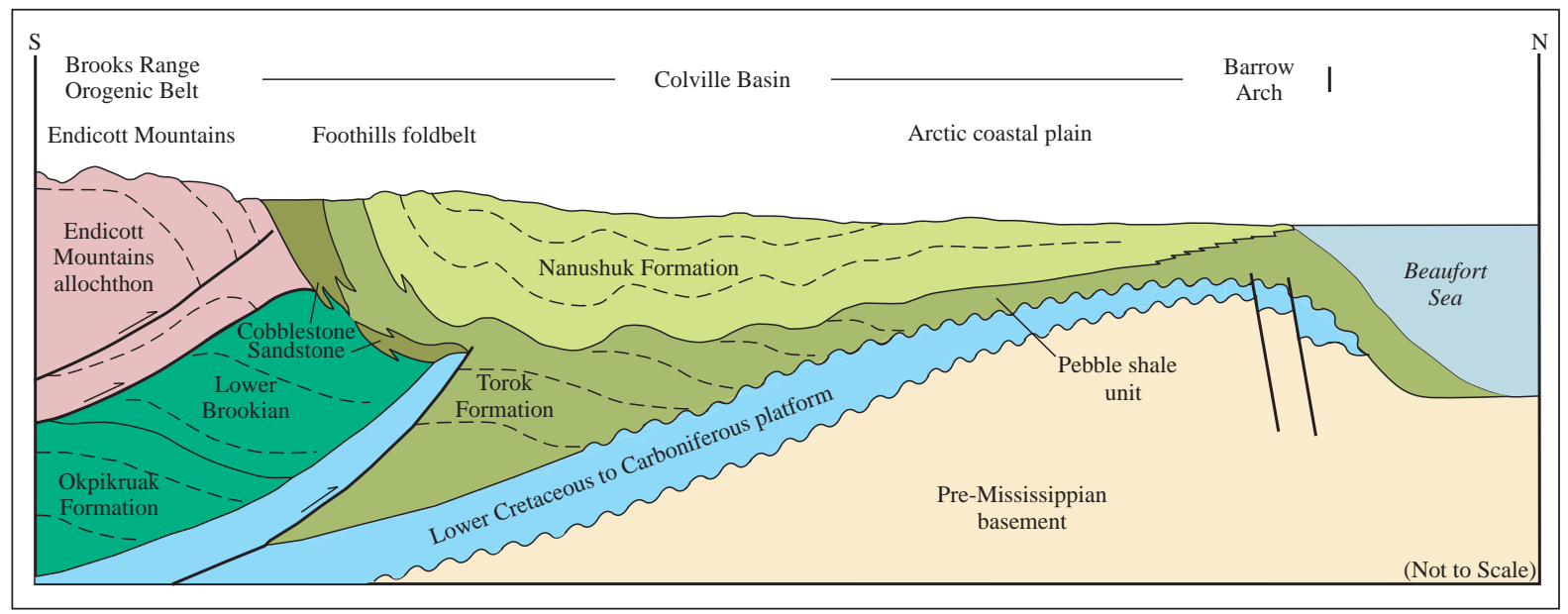

Figure 2. Diagrammatic section showing generalized stratigraphy and structure of Colville Basin.

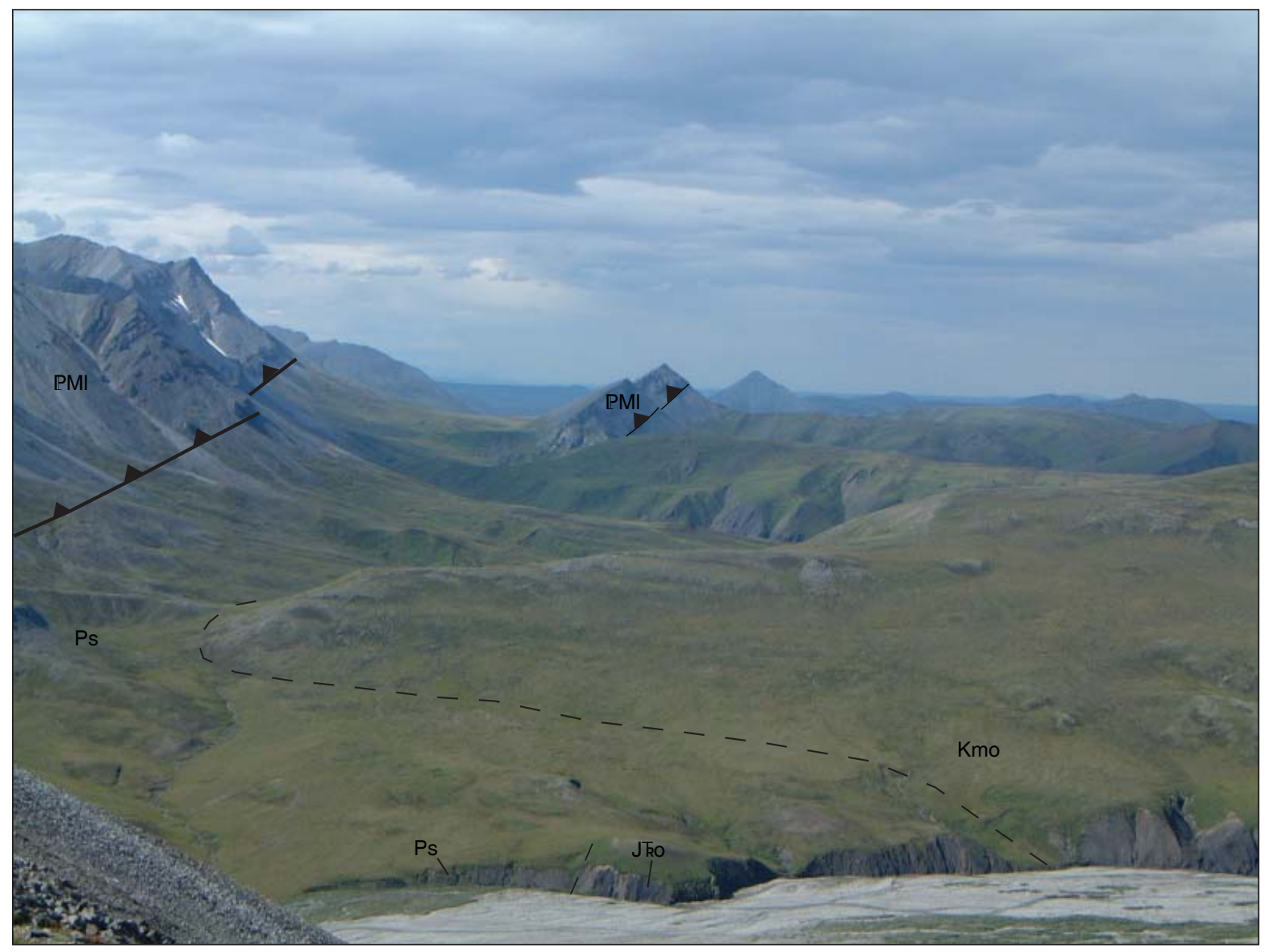

Figure 3. View westward along Endicott Mountains front at Cobblestone Creek, showing frontal thrust fault in Lisburne Group carbonates (PMl) (Sec. 19, T12S, R7E) and overturned exposures of Siksikpuk (Ps) and Otuk (JKo) Formations in west bank of Cobblestone Creek (Secs. 17 and 20, T12S, R8E). Lowland area north (to the right) of Otuk exposures is underlain by a zone of mélange and olistostrome (Kmo) in the disturbed belt that lies north of the mountain front. 


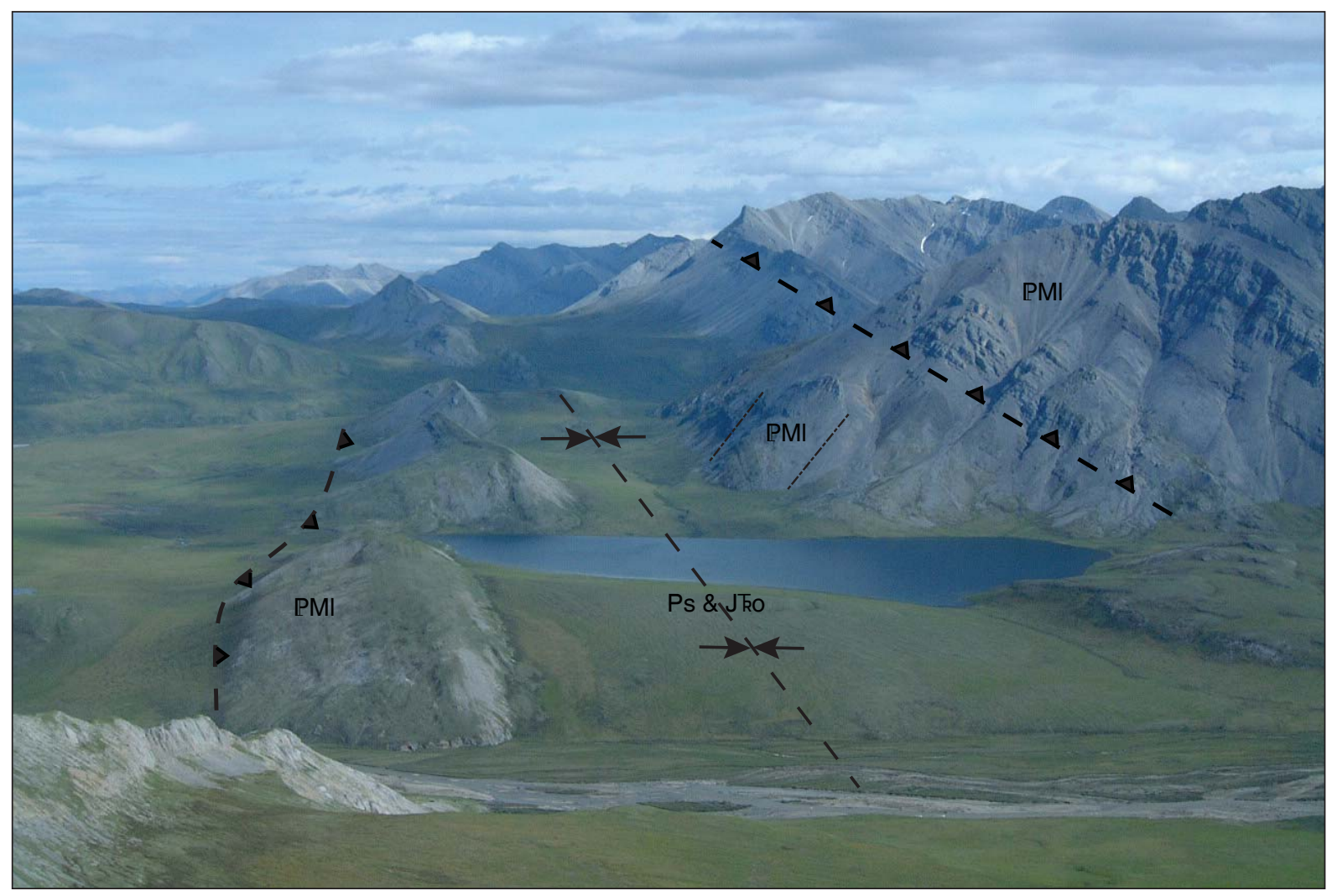

Figure 4. View eastward along Endicott Mountains front at Nanushuk Lake (Secs. 18 and 19, T12S, R7E) showing two thrust sheets of Lisburne Group limestone and dolomite (PMl). Intermittent exposures of Siksikpuk (Ps) and Otuk (JKo) Formations are present in a syncline in the lowland valley between the two thrust sheets of Lisburne Group.

\section{Disturbed belt-allochthonous rocks}

North of the mountain front is a thick section of Lower Cretaceous (Valanginian) graywacke turbidites of the Okpikruak Formation that belongs either to the Picnic Creek or to the Ipnavik River allochthon. Due to the absence of pre-Valanginian rocks underlying the Okpikruak Formation, the allochthon that this section represents cannot be determined. These rocks are exposed in the Peregrine Ridge anticline, which trends across the southern part of the disturbed belt north of the mountain front.

\section{Disturbed belt-parautochthonous rocks}

Overlying the Okpikruak Formation on the flanks of the Peregrine Ridge anticline is a thick section of mélange/olistostrome that crops out in a large area in the west-central part of the quadrangle (fig. 3). This unnamed mélange/olistostrome contains numerous large (up to $330 \mathrm{ft}[100 \mathrm{~m}]$ ) chaotic exotic blocks of gray to white chert and smaller blocks of greenish gray and black chert in a matrix of black, silty mudstone to sheared, scaly argillite. Also present in the southern part of the mélange is one large block of Lisburne Group limestone, a number of sheared blocks of Buchia limestone known as the coquinoid limestone (fig. 6), and Okpikruak graywacke that contains Buchia sublaevis of Valanginian age. The mélange appears to stratigraphically overlie the Okpikruak and contains debris from the upper part of the Endicott Mountains allochthon as well as from the Okpikruak Formation and the Permian to Jurassic Imnaitchiak Chert of the Picnic Creek or Ipnavik River allochthon. The Imnaitchiak Chert is widespread as a coherent unit in the lower part of both the Picnic Creek and Ipnavik River allochthons in the Killik River area, $110 \mathrm{mi}(180 \mathrm{~km})$ west of the Cobblestone Creek-May Creek area (Mull and others, 1987; Mull and others, 1994).

This unnamed mélange/olistostrome is interpreted as a gravitational mass transport deposit of debris derived from tectonically disrupted allochthonous rocks to the south. The unit is undated, but based on apparent stratigraphic relationships in the map area it is thought to be a proximal deposit coeval with or slightly younger than the lower part of the Fortress Mountain Formation (Aptian). Similar mélange/olistostrome deposits are present in 


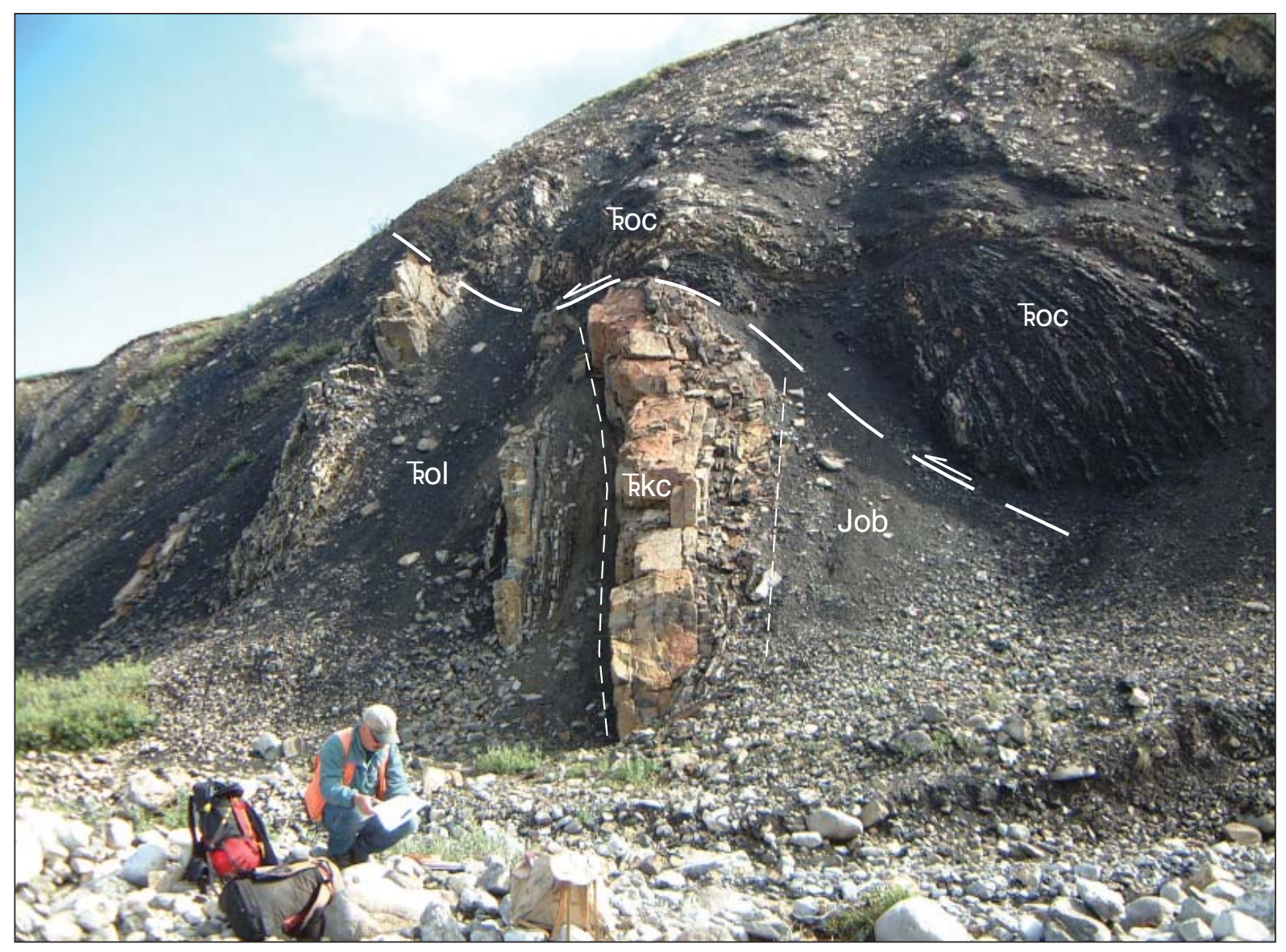

Figure 5. Structurally contorted Otuk Formation on east side of the west fork of May Creek at Endicott Mountains front (NE1/4, Sec. 16, T12S, R8E). Resistant unit is fine-grained quartzose sandstone correlative with Karen Creek Sandstone ( $\mathrm{kkc}$ ) of northeastern Brooks Range (Bodnar, 1989) overlying interbedded organic-rich black shale and limestone of limestone member of Otuk (on left) ( $\mathrm{kol})$. A few feet of Blankenship Member of Otuk Formation (Job) overlies the Karen Creek and is overlain by a thrust of thinly interbedded organic-rich black shale and chert of the chert member of the Otuk (koc).

the Kanayut River and Siksikpuk River-Tiglukpuk Creek map areas to the west (Harris and others, 2009; Peapples and others, 2007). The blocks were probably emplaced within the mélange/olistostrome either as the Endicott Mountains allochthon was overridden by thrust emplacement of the Picnic Creek or Ipnavik River allochthon, or during a subsequent stage of deformation in which the Endicott Mountains allochthon was uplifted by a breaching fault that pierced the overlying allochthon. Alternatively, the mélange blocks may represent olistoliths emplaced by gravitational sliding into the basin during the formation of the thrust belt and subsequently deformed by later stages of faulting and folding.

East of Cobblestone Creek, the mélange/olistostrome apparently trends laterally into poorly exposed graywacke that resembles the lower part of the Fortress Mountain Formation elsewhere in the foothills belt. No fossils have been obtained from either the mélange/olistostrome or the laterally equivalent graywacke, but based on its stratigraphic position overlying the Okpikruak Formation, we infer that it is coeval with at least part of the lower part of the Fortress Mountain Formation (see description in Harris and others, 2002).

\section{Disturbed belt - Cobblestone parautochthonous sequence}

The Cobblestone parautochthonous sequence lies north of the mélange/olistostrome belt and consists of a thin section of Upper Triassic to Lower Cretaceous (Valanginian) rocks of the Beaufortian sequence overlain by rocks representing the beginning of Brookian deposition. The Beaufortian Otuk Formation, Kingak Shale, and Buchia limestone coquina (fig. 7) are overlain by an unnamed phosphatic and manganiferous shale (Lower Cretaceous-Barremian) (fig. 8) and by the Lower Cretaceous Cobblestone Member of the Fortress Mountain Formation (revised 


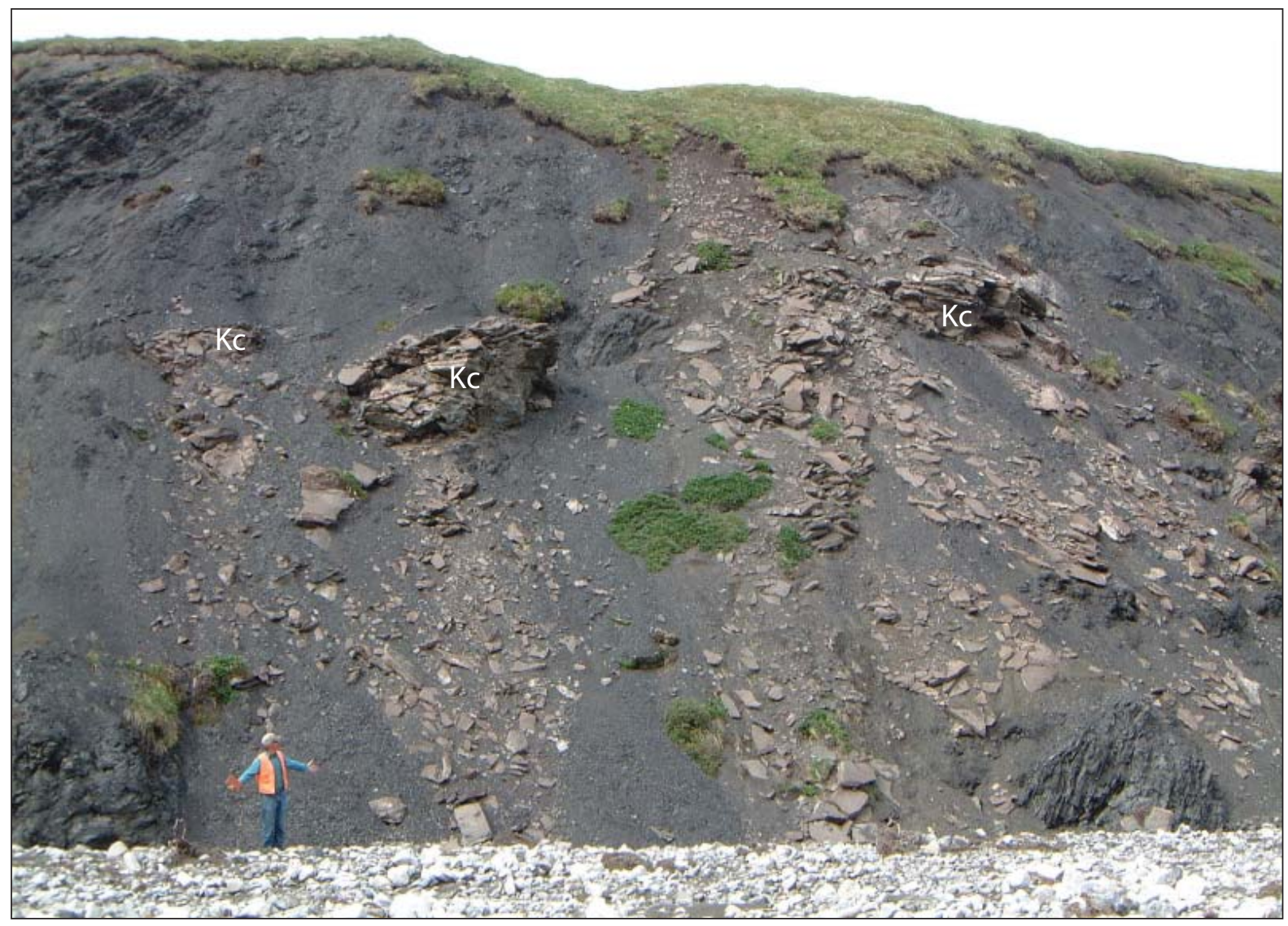

Figure 6. View of blocks of Buchia limestone coquina $(\mathrm{Kc})$ in sheared black shale groundmass of mélange of southern mélange/olistostrome belt along east fork of May Creek just north of mountain front (C, Sec. 12, T12S, R8E).

nomenclature; see below) (figs. 9 and 10), which constitute the initial deposits of the Brookian sequence (Lerand, 1973) in the Colville basin. These basal Brookian rocks consist of distal to proximal orogenic sediments derived from the Brooks Range thrust belt to the south and represent a reversal in depositional polarity from that of the underlying Beaufortian and Ellesmerian sequences.

The Cobblestone sandstone unit (informal name) was named by Kelley (1990) for a lithic sandstone and conglomerate unit that is well exposed in the Cobblestone Creek area. We redefine the Cobblestone sandstone unit as the Cobblestone Member (Aptian-Barremian) of the Fortress Mountain Formation. This designation acknowledges the affinity of these rocks to the Fortress Mountain Formation, but also indicates that there are significant mappable characteristics that allow the Cobblestone Member to be discriminated from the Fortress Mountain Formation. Although previous workers (Patton and Tailleur, 1964) mapped these rocks and overlying and underlying mudstones as Fortress Mountain Formation, most workers believe the Cobblestone sandstone and associated rocks to be older than and stratigraphically beneath the main complex of the Fortress Mountain Formation. The typical Fortress Mountain Formation is much thicker than the Cobblestone Sandstone Member and characteristically contains numerous thick synorogenic deposits that span the spectrum from fan delta to turbidite deposits and include numerous pebble to cobble conglomerate beds.

Regional stratigraphic and structural relationships suggest that the Cobblestone Member of the Fortress Mountain Formation in the parautochthonous sequence represents early stage foredeep deposition into the Colville basin. The Cobblestone Member contains abundant grains and clasts of light gray leached chert and Tasmanite, a distinctive organic-rich marlstone, indicating that at least part of the provenance of the Fortress Mountain Formation contained rocks of the Ipnavik River allochthon. We believe there is evidence that the Cobblestone Member and associated lower Brookian rocks were subsequently imbricated by thrust faulting during deposition of the upper Fortress Mountain, Torok, and Nanushuk Formations (discussed below). Although intraformational unconformities within the Fortress Mountain and Torok Formations cannot be demonstrated in the Cobblestone Creek-May 


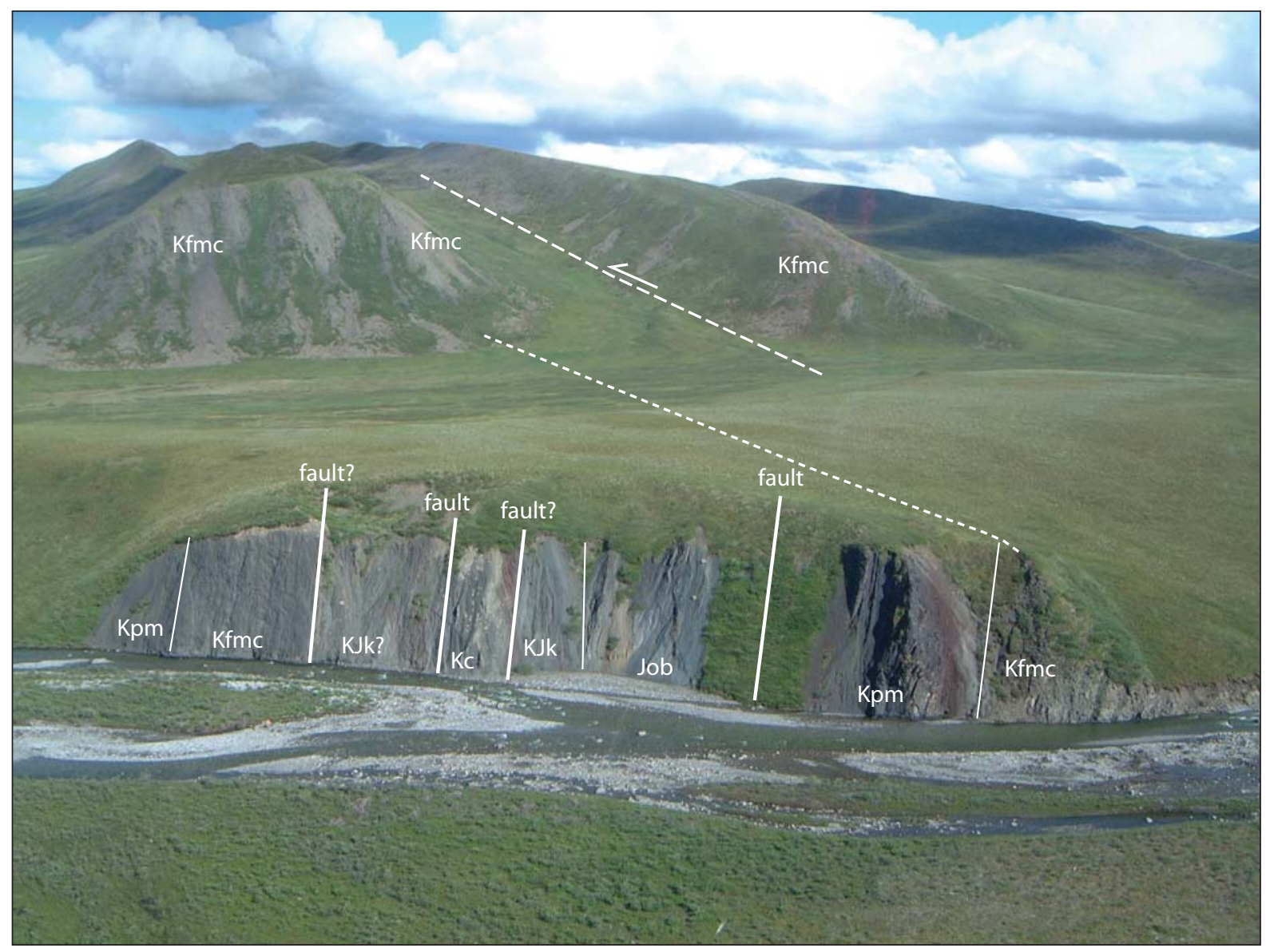

Figure 7.View of a structurally complicated bluff on east side of Cobblestone Creek (SW1/4 Sec. 1 and NW11/4 Sec. 12, T11S, R7E) exposing, from right to left, overturned Cobblestone sandstone (Kfmc) and phosphatic-manganiferous shale (Kpm), structurally contorted and faulted incompetent beds of Blankenship Member of Otuk Formation (Job), Kingak Shale (KJk), and Buchia limestone coquina $(\mathrm{Kc})$ in center of view, followed downstream by repeated sections of Kingak Shale, Cobblestone sandstone, and phosphatic-manganiferous shale. The stratigraphic tops in portions of this deformed section are downstream and can be interpreted to be on the north flank of an intensely faulted anticline or as the result of poly-phase deformation and a late stage of south-vergent back thrusting. This is a significant locality because it is one of the few locations in which organic-rich, oil-prone source rocks of the Jurassic Blankenship Member of the Otuk Formation are exposed in the thrust belt (see table A1 in Appendix).

Creek map area, an unconformity (or unconformities) at this stratigraphic interval is clearly evident elsewhere in the Colville basin, particularly on the east fork of the Etivluk River, west of the Cobblestone Creek area (Mull and others, 1996).

\section{Foothills foldbelt-foreland basin deposits}

Overlying the orogenic deposits of the Cobblestone Member of the Fortress Mountain Formation is a thick section ( $>3 \mathrm{mi}[>5 \mathrm{~km}]$ ) of Late to Early Cretaceous (Cenomanian to Aptian-Albian) foreland basin deposits of the Torok and Nanushuk Formations, which fills the Colville basin and forms most of the surface exposures of the southern part of the Brooks Range foothills foldbelt (fig. 2). The base of this sequence, the Torok Formation, consists of prodelta mudstone and shale deposited in advance of the prograding Nanushuk Formation (fig. 11) (Mull and others, 2003).

The Nanushuk Formation is a complex of deltaic and related alluvial sediments, greater than $3,300 \mathrm{ft}(1,000$ $\mathrm{m})$ thick in some areas, that overlies more than $20,000 \mathrm{ft}(6,000 \mathrm{~m})$ of fine-grained slope facies and pro-delta shale of the Torok Formation (Ahlbrandt and others, 1979; Huffman and others, 1985). In the Cobblestone Creek-May 

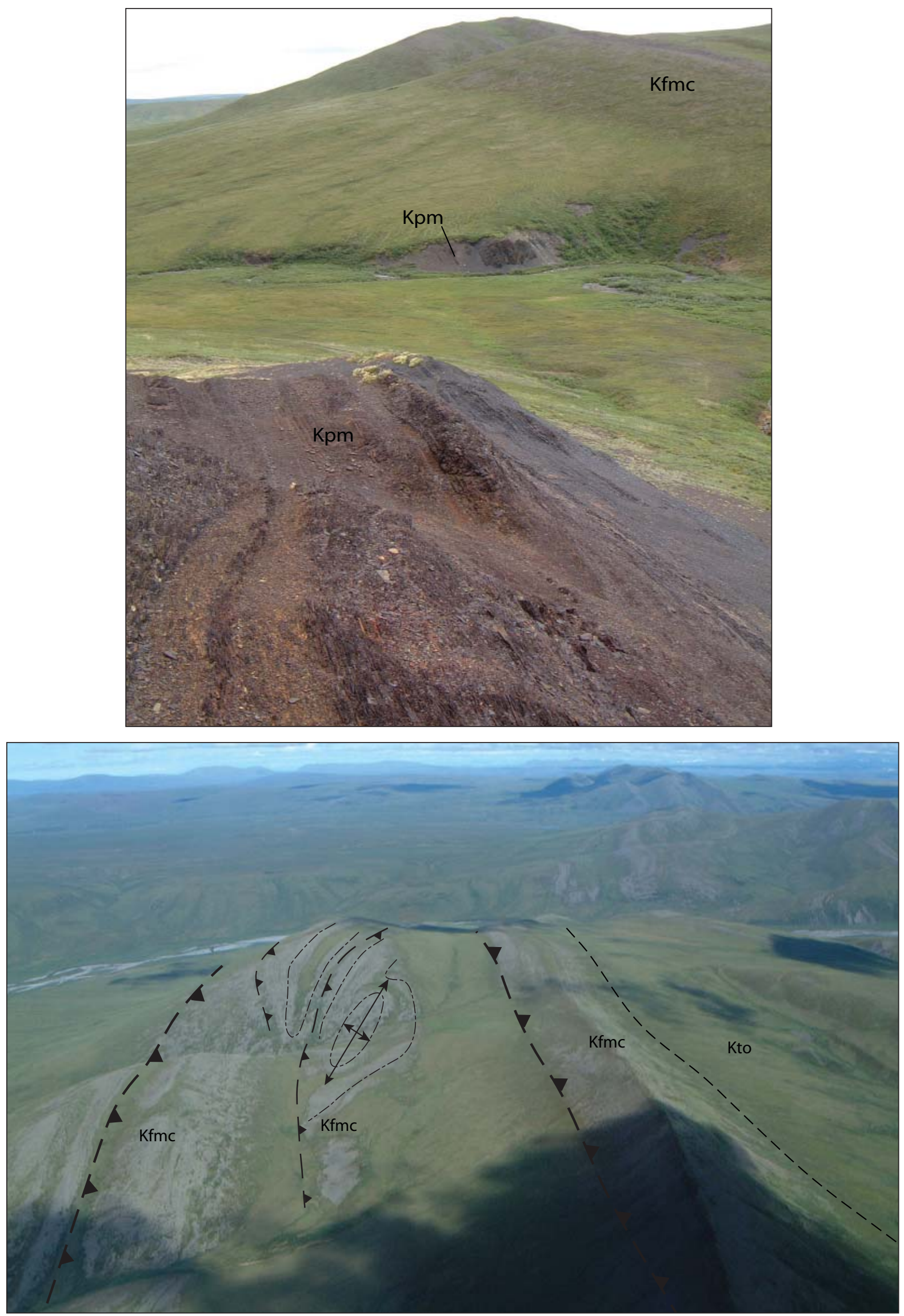


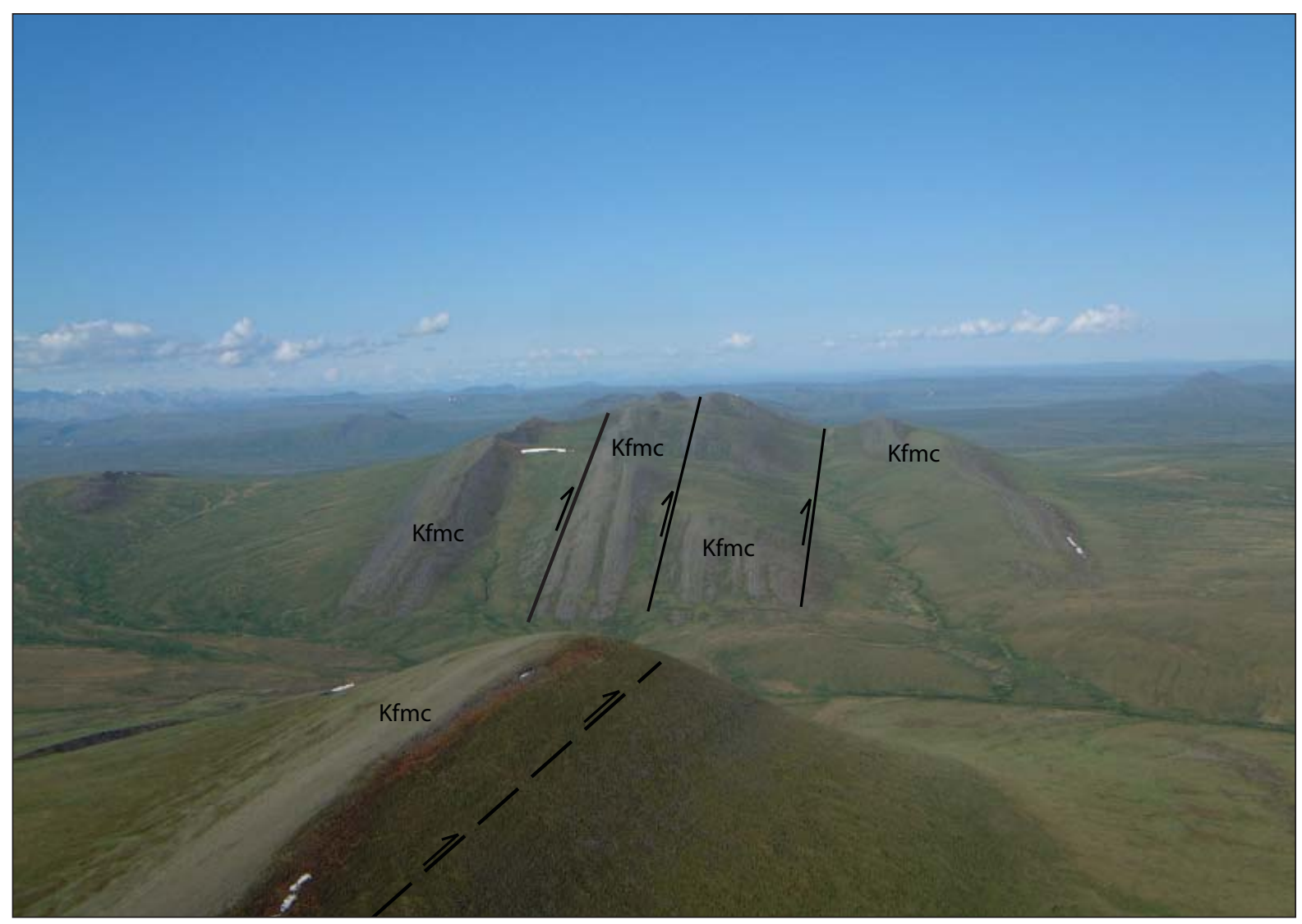

Figure 8 (page 10, top). View eastward of unnamed phosphatic-manganiferous shale (Kpm) on north side of Cobblestone ridges near western tributary of Cobblestone Creek (S1/2 Sec. 28, T10S, R7E). Cobblestone Member of Fortress Mountain Formation (Kfmc) forms high ridges to south.

Figure 9 (page 10, bottom). Eastward view of Cobblestone ridges west of Cobblestone Creek (SE1/4 Sec. 27, T10S, R10E) showing tightly folded beds of Cobblestone Member of Fortress Mountain Formation (Kfmc) in axis of tight anticlinal fold deformed by overlying thrust sheet of Cobblestone Member and Torok Formation (Kto) at right side of view. Abundant rubble cover commonly makes it difficult to observe such small-scale structural features within Cobblestone sandstone.

Figure 10 (above). View west along crest of Cobblestone ridges east of May Creek (Sec. 19, T10S, R9E) showing north-vergent, thrust-imbricated sheets of Cobblestone Member of Fortress Mountain Formation (Kfmc).

Creek map area, a delta complex termed the Umiat delta probably prograded northward or northeastward from a source in the area of the central Brooks Range (Mull, 1985; Huffman, 1985; Molenaar, 1975). These sediments merged with sediments of the Corwin delta (Huffman, 1985), which consists of eastwardly prograding sediments derived from a dominant source beneath the present Chukchi Sea (Mull, 1979). This foreland basin fill underlies most of the northern foothills belt and coastal plain of northern Alaska. The preserved southern limit of the Nanushuk Formation in the central Brooks Range foothills is at the Tuktu escarpment; its southern depositional limit is unknown.

In the northern part of the Cobblestone Creek-May Creek map area, the Nanushuk is overlain by the Upper Cretaceous Seabee Formation and by the Tuluvak Formation. The base of the Seabee Formation consists of a transgressive sequence of marine shale and bentonite, and the Tuluvak Formation consists of regressive sandstone and conglomerate. The Tuluvak Formation appears to prograde eastward into the eastern end of the Colville basin which, by Late Cretaceous time, was restricted to the east-central Arctic Slope. The eastward-prograding Schrader Bluff and Prince Creek Formations, which overlie the Tuluvak, have been eroded in the Cobblestone Creek-May Creek area but are present in adjacent quadrangles to the north. The preserved southern limit of both the Tuluvak and Seabee Formations is in the Cobblestone Creek-May Creek map area; however, their original southern and western depositional limits are unknown. 


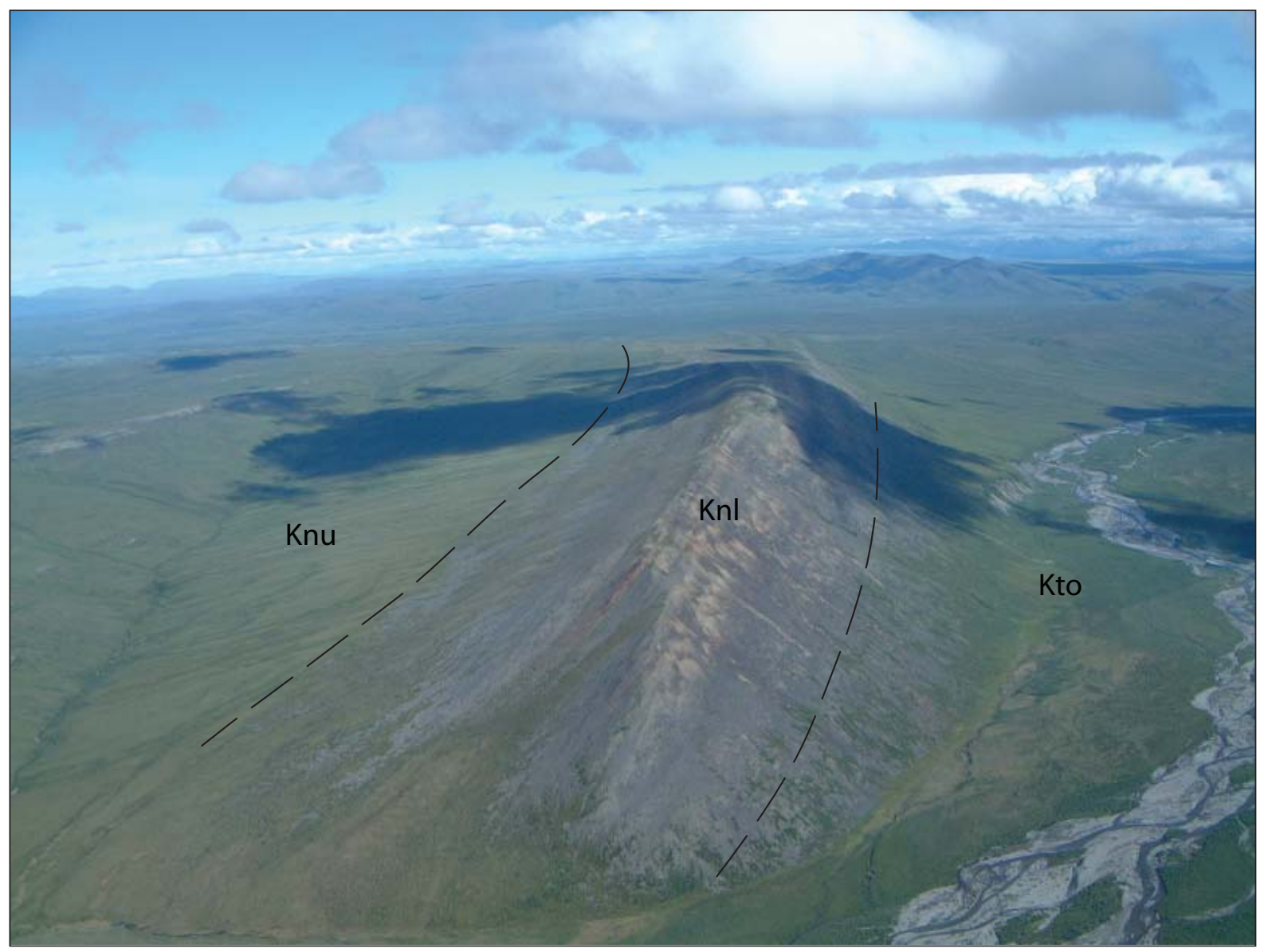

Figure 11. View east to north-dipping lower Nanushuk Formation (Knl) on Tuktu Escarpment at Cobblestone Creek (Sec. 16, T10S, R7E). Ledges of conglomerate in upper Nanushuk Formation (Knu) are exposed in axis of Arc Mountain syncline to the left. Tundra-covered lowland area south of escarpment is underlain by Torok Formation (Kto) and Cobblestone triangle zone.

\section{GENERALIZED STRUCTURE}

The discussion of the generalized structure in the Cobblestone Creek-May Creek area is given below within the framework of the three major structurally bounded belts or domains. From south to north these are: (1) the northern flank of the Brooks Range, (2) the "disturbed belt," and (3) the foothills foldbelt in the southern flank of the Colville basin (cross section A-A').

\section{Northern flank of the Brooks Range}

ENDICOTT MOUNTAINS ALLOCHTHON

At the south edge of the map area, rocks of the Endicott Mountains allochthon form the northern flank of the Brooks Range. This allochthon is the lowest of the major Brooks Range allochthons and forms the main mass of the Endicott Mountains of the east-central Brooks Range. In the map area, these rocks are composed primarily of folded imbricate thrust sheets of the competent cliff-forming limestone and dolomite of the Lower Pennsylvanian to Mississippian Lisburne Group (fig. 3). South of the map area, the Lower Mississippian to Upper Devonian Kanayut Conglomerate and Hunt Fork Shale form the lower part of the Endicott Mountains allochthon. At the northern mountain front, the thin section of relatively incompetent Permian to Lower Cretaceous rocks overlies the Lisburne Group, and is locally preserved on the hanging wall of a north-vergent thrust fault that marks the northern mountain front (fig. 4). In the line of cross section A-A', this bounding thrust fault at Cobblestone Creek is one of a series of folded, north-vergent thrust faults in the Lisburne and younger rocks that regionally mark the mountain front. These thrust faults are interpreted to represent out-of-sequence faulting in which the Endicott Mountains allochthon 
was uplifted following emplacement of the structurally overlying Picnic Creek or Ipnavik River allochthon (Mull and others, 1987) and the unnamed mélange/olistostrome that lies north of the mountain front.

\section{Disturbed Belt}

In the Cobblestone Creek-May Creek area, the disturbed belt north of the mountain front consists of two discrete trends of allochthonous and parautochthonous rocks. The southern part of the disturbed belt is composed of the thick, coherent section of turbidites of the Lower Cretaceous Okpikruak Formation of the Picnic Creek or Ipnavik River allochthon, overlain by the unnamed mélange/olistostrome. The Okpikruak Formation forms the upper part of either the Picnic Creek or Ipnavik River allochthon, however, the absence of rocks underlying the Okpikruak make it impossible to determine which of the allochthons is represented.

Picnic Creek or IpNavik River alLochthon

Graywacke turbidites of the Lower Cretaceous (Valanginian) Okpikruak Formation that represent the upper part of either the Picnic Creek or Ipnavik River allochthon crop out in a tightly folded, slightly overturned anticline that is here named the Peregrine Ridge anticline. This anticline can be traced on the map for about $8 \mathrm{mi}(13 \mathrm{~km})$ from May Creek to west of Peregrine Creek, where it plunges abruptly to the southwest. The northeast-southwest trend of the anticline conspicuously converges with the general east-west trend of the mountain front to the south and also contrasts with the structural trends elsewhere in the map area. No satisfactory explanation has been proposed for this anomalous trend.

MÉLANGe/olistostrome Belt

For most of its southwest-northeast extent, the Peregrine Ridge anticline is flanked by the unnamed mélange/ olistostrome unit that is thought to be coeval with or slightly younger than the lower part of the Fortress Mountain Formation (see description above).

The northern limit of the northern mélange/olistostrome belt and its contact with the Cobblestone parautochthonous sequence is mostly within a broad area of Quaternary deposits; however, south of the junction of Peregrine Ridge and Cobblestone Creek the mélange belt appears to overlie a belt of south-dipping Torok Formation and Cobblestone Sandstone. Although the contact between the mélange/olistostrome belt and Torok shale is not exposed, it is inferred to be either a regional thrust fault or a regional detachment in which parautochthonous rocks were gravitationally transported northward into the basin. The detachment scenario may not necessarily represent thrusting of older over younger rocks.

In the Kanayut River map area west of the Nanushuk River (Harris and others, 2009), the unnamed mélange/ olistostrome trends westward into an area in which the mélange is better exposed and which contains more extensive coherent exposures of Okpikruak Formation and less shaly matrix than in the Cobblestone Creek area.

Cobblestone parautochthonous Sequence

The northern part of the disturbed belt is here termed the Cobblestone parautochthonous sequence. It consists of a linear belt of structurally imbricated and folded rocks of the lower part of the Torok Formation (Aptian), the Cobblestone Member of the Fortress Mountain Formation (Aptian; figs. 9 and 10), and the underlying Upper Neocomian (Barremian?) unnamed phosphatic-manganiferous shale (fig. 8). The phosphatic-manganiferous shale and Cobblestone Member of the Fortress Mountain Formation represent the earliest Brookian foredeep deposition in this part of the Colville basin. These deposits overlie the thin and incompetent section of the Buchia limestone coquina, Kingak Shale, and the Otuk or Shublik Formation (fig. 7), which seem to overlie a detachment surface at the base of the Cobblestone parautochthonous sequence. This thin Lower Cretaceous to Triassic section represents either the upper part of the parautochthonous basement to the Cretaceous Colville basin or strata detached from the top of the Endicott Mountains allochthon. In the map area, the northern limit of the disturbed belt and the Cobblestone parautochthonous sequence is the surface trace of a regional north-vergent thrust fault here named the Cobblestone fault, which trends east-northeast across the map area. This thrust fault is the surface trace of the thrust at the base of the Cobblestone parautochthonous sequence.

Regional stratigraphic and structural relationships suggest that the Cobblestone Member of the Fortress Mountain Formation in the parautochthonous sequence consists of early stage foredeep deposition into the middle Cretaceous Colville basin. The Cobblestone Member contains abundant grains and clasts of light gray leached chert and Tasmanite, a distinctive organic-rich marlstone, indicating that at least part of the provenance of the Fortress Mountain Formation contained rocks of the Ipnavik River allochthon. We believe there is evidence that 
the Cobblestone Member and associated lower Brookian rocks were subsequently imbricated by thrust faulting during deposition of the upper Fortress Mountain, Torok, and Nanushuk Formations. Syndepositional deformation within the Nanushuk Formation is documented in a similar structural setting in the DeLong Mountains (Mull and others, 2000). Although not documented in the east-central Brooks Range foothills, we believe that similar syndepositional structural relationships may be present in the Cobblestone Creek area.

\section{TRIANGLE ZONE}

The Cobblestone parautochthonous sequence is bounded on the north by a triangle zone that separates it from the foothills folded belt to the north. The presence of a triangle zone is indicated by the marked contrast in structural style and shortening between the Cobblestone parautochthonous sequence on the south and the foothills folded belt to the north (discussed below). The triangle zone is formed by the Cobblestone fault on the south, and on the north by an inferred south-vergent backthrust, here named the Nanushuk backthrust, which underlies a passive roof sequence formed by the competent rocks of the Nanushuk Formation in the foothills folded belt (discussed below). The inferred backthrust is not exposed, but is probably a diffuse zone of faulting located within shales and mudstones of the upper part of the Torok Formation, which underlies the Nanushuk Formation. Regionally, the preserved southern limit of the Nanushuk Formation, which overlies the Nanushuk backthrust, forms a relatively persistent west-northwest-trending ridge or upland plateau commonly referred to as the Tuktu escarpment (fig. 11). This escarpment rises above a regional tundra-covered lowland area to the south that is underlain dominantly by shales and mudstones of the Torok Formation. The escarpment can be traced west-northwestward from the Cobblestone Creek-May Creek map area for more than $145 \mathrm{mi}(235 \mathrm{~km})$ to the Colville River, and is interrupted only by a number of superimposed northward-flowing river drainages. In the Cobblestone Creek-May Creek map area, the Tuktu escarpment trends nearly east-west and converges with the east-northeast-trending Cobblestone fault.

Throughout most of its extent, the lower part of the escarpment-forming Nanushuk Formation dips $45^{\circ}$ to $60^{\circ}$ northward above the Nanushuk backthrust. However, when traced eastward from Cobblestone Creek, the northward dip of the lower Nanushuk Formation appears to increase progressively to nearly vertical east of May Creek as the trend converges with that of the east-northeast-trending Cobblestone fault. We believe that this increase in dip of the Nanushuk Formation and the underlying Nanushuk backthrust may be the result of drag by a later stage of movement along the Cobblestone fault. To the east, this fault probably became a breaching fault and broke through the overlying passive roof sequence of the Nanushuk Formation. The basis for this interpretation includes the eastward increase of dip in the Nanushuk Formation at the Tuktu escarpment, and the projection of the Cobblestone fault northeastward in the adjacent Philip Smith Mountains Quadrangle. There, the fault is nearly parallel with the trend of the Philip Smith Mountains front, and the throw on the fault appears to increase markedly so that lower stratigraphic levels south of the fault are topographically higher than outliers of the Nanushuk Formation not far to the north.

\section{FOOTHILLS FOLDBELT}

Rocks of the foothills foldbelt form the northern half of the Cobblestone Creek-May Creek map area and consist of the Nanushuk (Albian-Cenomanian), Seabee (Turonian), and Tuluvak (Turonian-Coniacian) Formations. These rocks form the relatively competent passive roof sequence that overlies relatively incompetent shale of the Torok Formation. This passive roof sequence is regionally deformed into a series of long, linear, relatively broad, gentle synclines and sharp anticlines that characterize the structure of the southern and central parts of the Colville basin. The Arc Mountain anticline in the northern part of the Cobblestone Creek-May Creek map area is typical of these anticlines (fig. 12). These structures are developed above a detachment zone in the incompetent mudstones of the Torok Formation, which generally is exposed only in the cores of the anticlines (Mull, 1985). Seismic data show that the folds in the Nanushuk and overlying units are detached from the underlying lower Cretaceous and older rocks in the deeper parts of the Colville basin, which generally dip gently southward (Mull and others, 1987; Mull, 1989). Throughout most of the foldbelt, the synclines are generally either symmetrical or exhibit slight northward asymmetry with south flanks somewhat steeper than the north flanks. Regionally, most of the anticlines also appear to be relatively symmetrical, but in some areas the crests of the anticlines are marked by high-angle, north- or south-vergent thrust faults with significant amounts of throw. This pattern suggests regional north-vergent shortening of the Nanushuk and overlying units above the Torok detachment zone.

In the Cobblestone Creek-May Creek map area, the Arc Mountain syncline appears to be slightly asymmetrical, with dips on its south flank somewhat steeper than on its north flank. The Arc Mountain anticline also appears to be relatively symmetrical in the map area; however, a few kilometers west of the Nanushuk River, just west of the 
map area, the anticline abruptly becomes steeply asymmetrical to the south. North-dipping marine sandstones of the lower part of the Nanushuk Formation on the north flank of the anticline clearly override steeply dipping to vertical nonmarine conglomerate beds of the upper part of the Nanushuk that form the south limb of the anticline. We assume that displacement on the south-vergent back-thrust that underlies the lower Nanushuk may die out in the core of the Arc Mountain anticline in the Cobblestone Creek-May Creek map area, although there are few exposures to confirm the presence of a back-thrust in the map area.

\section{High-ANGLE FAULTS}

Two northeast-southwest-trending, en echelon, high-angle faults are mapped in the foothills foldbelt north of the Cobblestone triangle zone. These faults are inferred on the basis of structural relationships in the adjacent outcrops of the Tuluvak and Nanushuk Formations. Surface expression of these faults is entirely concealed by Quaternary alluvium and glacial moraine, and the inferred displacement across these faults is relatively small. These faults are inferred to trend about $\mathrm{N} 30^{\circ} \mathrm{E}$ and are transverse to the predominant east-west structural trends in the foldbelt. At the north end of the map area, the northern fault apparently bounds the eastern end of the May Creek syncline, in which folding of the Tuluvak Formation defines the westerly plunge of the syncline. To the south, resistant beds of the Nanushuk Formation on the north flank of the Arc Mountain anticline are offset with an apparent left-lateral sense of movement. The inferred offset across the fault is about $0.3 \mathrm{mi}(0.5 \mathrm{~km})$. The en echelon southern fault, which transects the Arc Mountain syncline, is defined more clearly than the northern fault, and apparently influences the linear trace of a small tributary of May Creek. East of the fault, the surface trace of the lower part of the

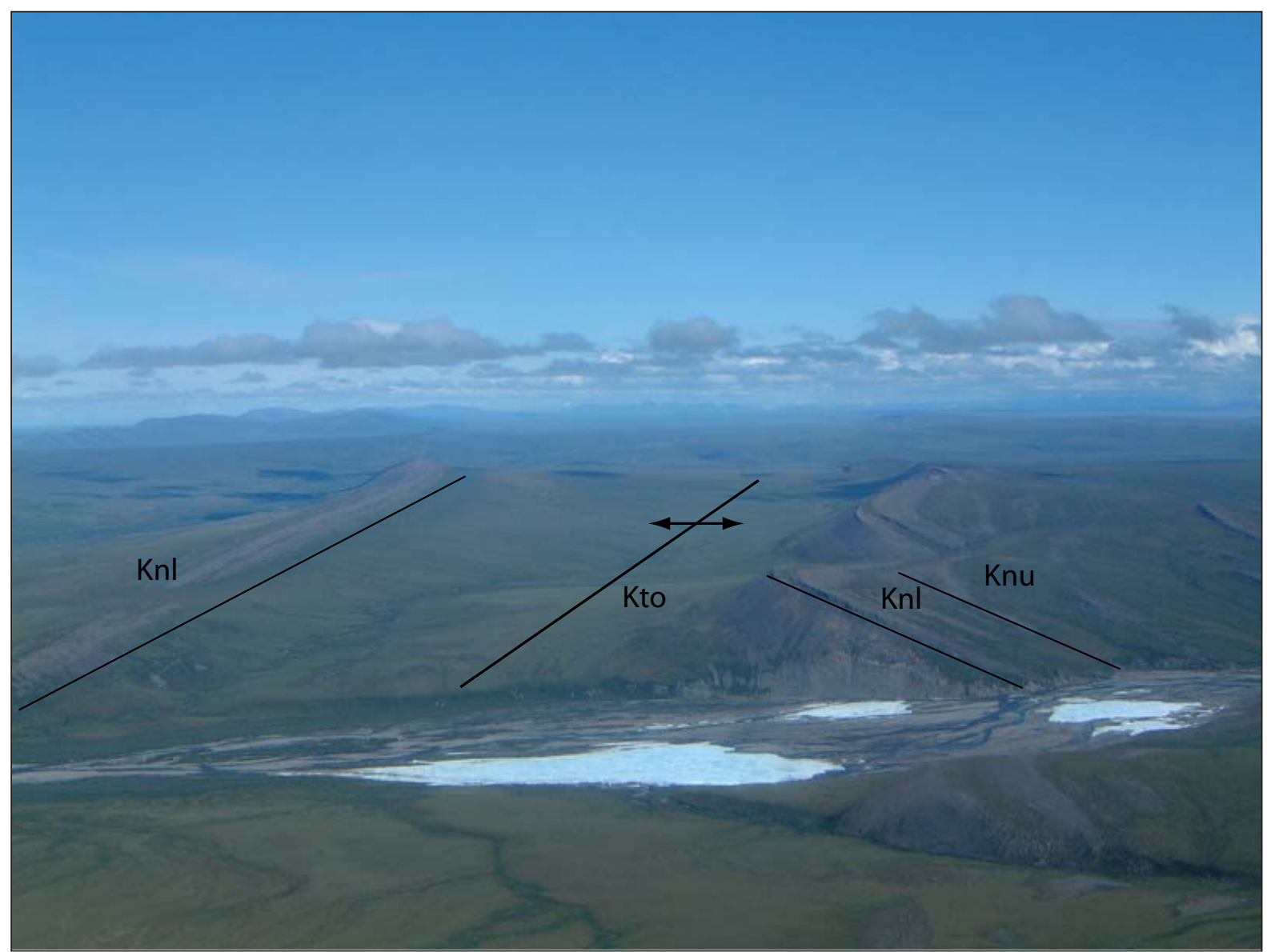

Figure 12. View east to Arc Mountain anticline at Nanushuk River (Secs. 18 and 19, T9S, R7E). Upper part of Torok Formation (Kto) and transition into marine sandstones of lower Nanushuk Formation (Knl) are well exposed in river bluff to right. Upward transition into marginal marine and nonmarine upper Nanushuk (Knu) is exposed in discontinuous ledges in axis of Arc Mountain syncline to right. 
Nanushuk Formation on the south flank of Arc Mountain anticline appears to be deflected to the north. In the axis of Arc Mountain syncline east of the inferred fault, resistant beds in the upper part of the Nanushuk Formation define local east plunge and the outcrop pattern apparently defines a local basin in the Nanushuk.

Although these high-angle faults in the Cobblestone Creek area are not well constrained and do not seem to have large displacement, they may be part of a more prominent system of northeast-southwest-trending left-lateral wrench faults that crosscut the foldbelt. Similar faults that are more constrained by outcrop data are present in the Philip Smith Mountains Quadrangle to the east (Harris and others, 2002) and in the Umiat Quadrangle to the north (Mull and others, 2002).

\section{Summary of Structural History}

Regional structural and stratigraphic relationships in the Brooks Range indicate a major north-vergent orogenic event in the Early Cretaceous (Neocomian) with a few hundred miles (several hundred kilometers) of net crustal shortening. This event was followed by regional uplift in the core of the Brooks Range in Albian to Cenomanian time (Mull, 1982; Mayfield and others, 1988; Moore and others, 1994). Thermal maturity data in the Cobblestone Creek-May Creek map area (discussed in the section on hydrocarbon source rock potential) suggest middle Cretaceous (Aptian-Albian) deformation and some uplift of the Cobblestone parautochthonous sequence. Early Tertiary orogenesis is indicated by folding of the foreland basin deposits of the Nanushuk Formation and overlying Upper Cretaceous to basal Tertiary units in the Colville basin above the inferred decollement within the Torok Formation. Apatite fission-track data by Paul O'Sullivan (discussed later in this report) document two stages of rapid uplift and cooling at the Endicott Mountains front and in the foothills belt at $\sim 60 \mathrm{Ma}$ (late Paleocene) and $\sim 45 \mathrm{Ma}$ (middle Eocene). Development of the triangle zone at the northern limit of the Cobblestone parautochthonous sequence probably occurred at the time of the $\sim 60 \mathrm{Ma}$ event. Further deformation probably occurred at $\sim 45 \mathrm{Ma}$ in the area of the triangle zone and within the cores of some of the foothills anticlines to the north, such as Arc Mountain anticline. South-vergent backthrusting of the passive roof sequence of competent Nanushuk Formation occurred between the Cobblestone parautochthonous sequence and the Tuktu escarpment, and locally within the cores of some of the foothills anticlines such as Arc Mountain anticline.

\section{Depositional and structural evolution of the Cobblestone Creek-May Creek area}

The depositional and structural evolution of the Cobblestone Creek-May Creek area is summarized below:

1. Carboniferous: Deposition of thick platform carbonate rocks of the Lisburne Group in the area of the future Endicott Mountains allochthon.

2. Permian: Deposition of silty shale of the Siksikpuk Formation in a distal shallow marine setting.

3. Triassic: Deposition of thin-bedded limestone and organic-rich shales of the Otuk Formation.

4. Lower to lower Upper Jurassic (Oxfordian): Deposition of condensed organic-rich black shales of the Blankenship Member of the Otuk Formation in the area of the future Endicott Mountains allochthon. The Blankenship Member is correlative with the lower part of the autochthonous Kingak Formation of the North Slope.

5. Upper Jurassic to Lower Cretaceous (Lower Neocomian, Berriasian): Beginning of the Brookian orogeny south of the map area in the area of the future Picnic Creek and Ipnavik River(?) allochthons. In the map area, no deposition has been documented in the incipient southern Colville basin.

6. Lower Cretaceous (Valanginian): Deposition of Okpikruak Formation turbidites in the area of the future Picnic Creek and Ipnavik River(?) allochthons in the basin south of the map area. These sediments were derived from the Brookian orogenic belt, coeval with deposition to the north of outer shelf Buchia coquina limestone, and silty shale of the Kingak Formation in the area of the future Endicott Mountains allochthon and Cobblestone parautochthonous belt.

7. Upper Neocomian (Barremian?): Deposition of basal Brookian phosphatic-manganiferous shale in a restricted portion of the Colville basin.

8. Early Aptian: Deposition of northward prograding, channelized and non-channelized turbidites and lesser amounts of debris-flow sediments of the Cobblestone Member of the Fortress Mountain Formation and the lower Fortress Mountain Formation, and beginning of deposition of distal deposits of the Torok Formation. Probable emplacement of the unnamed mélange/olistostrome and the Picnic Creek or Ipnavik River allochthon in the proximal portion of the Colville basin.

9. Middle Aptian: Probable beginning of north-vergent thrusting in the map area, uplift of the Cobblestone parautochthonous sequence, the Picnic Creek or Ipnavik River allochthon, and the overlying mélange/ olistostrome, and the leading edge of the Endicott Mountains allochthon in the thrust belt. 
10. Late Aptian: Beginning of the deposition of prograding shelf slope mudstone and shale of the Torok Formation, filling accommodation in the southern Colville basin, probably synchronous with continued uplift of the leading edge of the Cobblestone parautochthonous sequence and the Endicott Mountains allochthon.

11. Early Cretaceous (Albian) to Late Cretaceous (Cenomanian): Deposition of the Torok and Nanushuk Formations prograding across the Colville basin in the northern part of the map area, probably synchronous with continued uplift of the leading edge of the Cobblestone parautochthonous sequence and the Endicott Mountains allochthon. These sediments were probably derived from major uplift and deformation west and south of the map area and from unroofing of the Endicott Mountains allochthon in the southern Endicott Mountains.

12. Late Cretaceous (Turonian): Marine transgression and deposition of organic-rich shales and bentonites of the basal Seabee Formation. This phase was followed by regressive deposition of the upper Seabee and the eastward prograding nonmarine to marine sandstone and conglomerate of the Tuluvak Formation, which was derived from the Endicott Mountains allochthon.

13. Late Cretaceous: Probable deposition of marine sediments of the Schrader Bluff and Prince Creek Formations, which are now eroded from the map area.

14. Early Tertiary (60 Ma): Renewed thrusting, out-of-sequence faulting, and uplift of the Endicott Mountains allochthon to form the present Endicott Mountains front. Renewed thrusting and folding in the Cobblestone parautochthonous belt. Regional shortening in the southern part of Colville basin and development of regional folds in the Nanushuk above the decollement in the Torok Formation. Development of a southvergent backthrust in the Torok Formation at the triangle zone between the Cobblestone parautochthonous sequence and the south side of the Tuktu escarpment below the passive roof of the Nanushuk Formation.

15. Middle Tertiary: Regional uplift in the Philip Smith Mountains to the east of the map area, and probable regional breakthrough of the Cobblestone fault upward through the Nanushuk passive roof at the northern edge of the Cobblestone parautochthonous sequence.

\section{HYDROCARBON SOURCE ROCK POTENTIAL AND THERMAL MATURITY ANOMALIES}

\section{TRIASSIC-JURASSIC SOURCE ROCKS}

Organic geochemistry and micropaleontology data from the Cobblestone Creek-May Creek map area are summarized in table A1 in Appendix. Most of the hydrocarbon source rock potential in the map area is confined to the Triassic to Jurassic Otuk Formation. This unit is lithologically similar to and coeval with the Shublik Formation, which is one of the major hydrocarbon source rock units of the Arctic Slope subsurface. The Otuk Formation is found both at the top of the Endicott Mountains allochthon at the mountain front (fig. 5) and at the base of the Cobblestone parautochthonous sequence in the disturbed belt. The Otuk is relatively thin - with a stratigraphic thickness of less than $330 \mathrm{ft}(<100 \mathrm{~m})$ —but the Upper Triassic limestone member contains numerous beds of black, sooty, organic-rich shale and limestone that yield measured total organic carbon (TOC) from 4 to 9 percent. The Jurassic Blankenship Member of the Otuk is even richer than the limestone member, and consists almost entirely of organic-rich shale and marl (fig. 9), with many analyses yielding from $>5$ percent to $>10$ percent TOC (table A1 in Appendix). Micropaleontology data suggest that the Blankenship ranges from lower Upper Jurassic to Lower Jurassic (Oxfordian to Pliensbachian; table A1 in Appendix), and is therefore coeval with the much thicker lower part of the Kingak Shale of the northern Arctic Slope in the area of Prudhoe Bay and the National Petroleum Reserve-Alaska (NPRA). Seismic data from NPRA show a persistent pattern of clinoforms that indicate southward progradation of the Kingak. The Blankenship Member thus appears to represent the condensed distal deposits of the thicker Kingak Shale to the north, which also is considered to contain significant intervals of potential hydrocarbon source rock.

Along the mountain front in the Cobblestone Creek map area, the Otuk Formation on the Endicott Mountains allochthon is thermally overmature for generation of oil. Vitrinite reflectance $\left(\mathrm{R}_{\mathrm{o}}\right)$ values from samples of this formation range from 2.1 to $>2.5$ percent $R_{o}$, and maximum temperature $\left(T_{\max }\right)$ ranges from $460^{\circ}$ to $>530^{\circ} \mathrm{C}$ (fig. 13 ). As a consequence of the high thermal maturity, the hydrogen index (HI) is low, generally $<15$, indicating that these rocks along the mountain front have generated and expelled most of their hydrocarbons.

In the disturbed belt north of the Endicott Mountains front, the Cobblestone parautochthonous sequence contains thrust slivers of both the Upper Triassic and Jurassic portions of the Otuk Formation. Measured TOC values in 
the Upper Triassic part of the Otuk Formation range to $>10$ percent TOC (table A1 in Appendix), and are comparable to those at the mountain front. A thin section of the Jurassic Blankenship Member exposed at a locality on Cobblestone Creek and on a tributary of May Creek (fig. 9) has even higher TOC than at the mountain front, and ranges up to 14 percent TOC (table A1 in Appendix).

Thermal maturity in the Otuk Formation in the Cobblestone parautochthonous belt is markedly lower than in the coeval rocks at the mountain front. The small exposure of the Otuk on Cobblestone Creek at the northern edge of the parautochthonous belt yields vitrinite reflectance values ranging from 1.6 percent to 1.9 percent $R_{o}$ and $T_{\max }$ values of $460^{\circ}$ to $490^{\circ} \mathrm{C}$. The surface $\mathrm{R}_{\mathrm{o}}$ values are shown along line of section $\mathrm{A}-\mathrm{A}^{\prime}$ on the map sheet.

In the central part of the parautochthonous belt, samples of the Blankenship Member collected from localities on Cobblestone Creek and the tributary of May Creek have vitrinite reflectance values from 1.17 percent to 1.67 percent $\mathrm{R}_{\mathrm{o}}$ and measured $\mathrm{T}_{\max }$ of $444^{\circ}$ to $461^{\circ} \mathrm{C}$. In the northern part of the belt, hydrogen index (HI) values range from 24 to 59, suggesting that these rocks have generated and expelled most of their liquid hydrocarbons. In the central part of the belt, however, samples of the Blankenship Member yield HI values from 45 to 200, suggesting that some of these rocks are still capable of generating liquid hydrocarbons. These indicators of thermal maturity of the Otuk Formation in the Cobblestone parautochthonous belt indicate that, at their maximum burial temperatures and prior to uplift and cooling, these rocks had passed through oil generation and were well into the zone of dry gas generation (fig. 13). Although the Triassic and Jurassic rocks in the Cobblestone parautochthonous belt apparently represent thrust slivers uplifted from the depths of the present Colville basin, their level of thermal maturity is lower than expected for rocks uplifted from the bottom of such a basin. Regional cross sections that are based on projections of seismic and subsurface well data suggest that Jurassic and Triassic strata in the southern part of the Colville basin are at a depth of $>3 \mathrm{mi}(>5 \mathrm{~km}$ ) (Mull and others, 1987; Howell and others, 1992; Moore and others, 1994; Fuis and others, 1997). Rocks at this depth should be thermally overmature for oil generation and

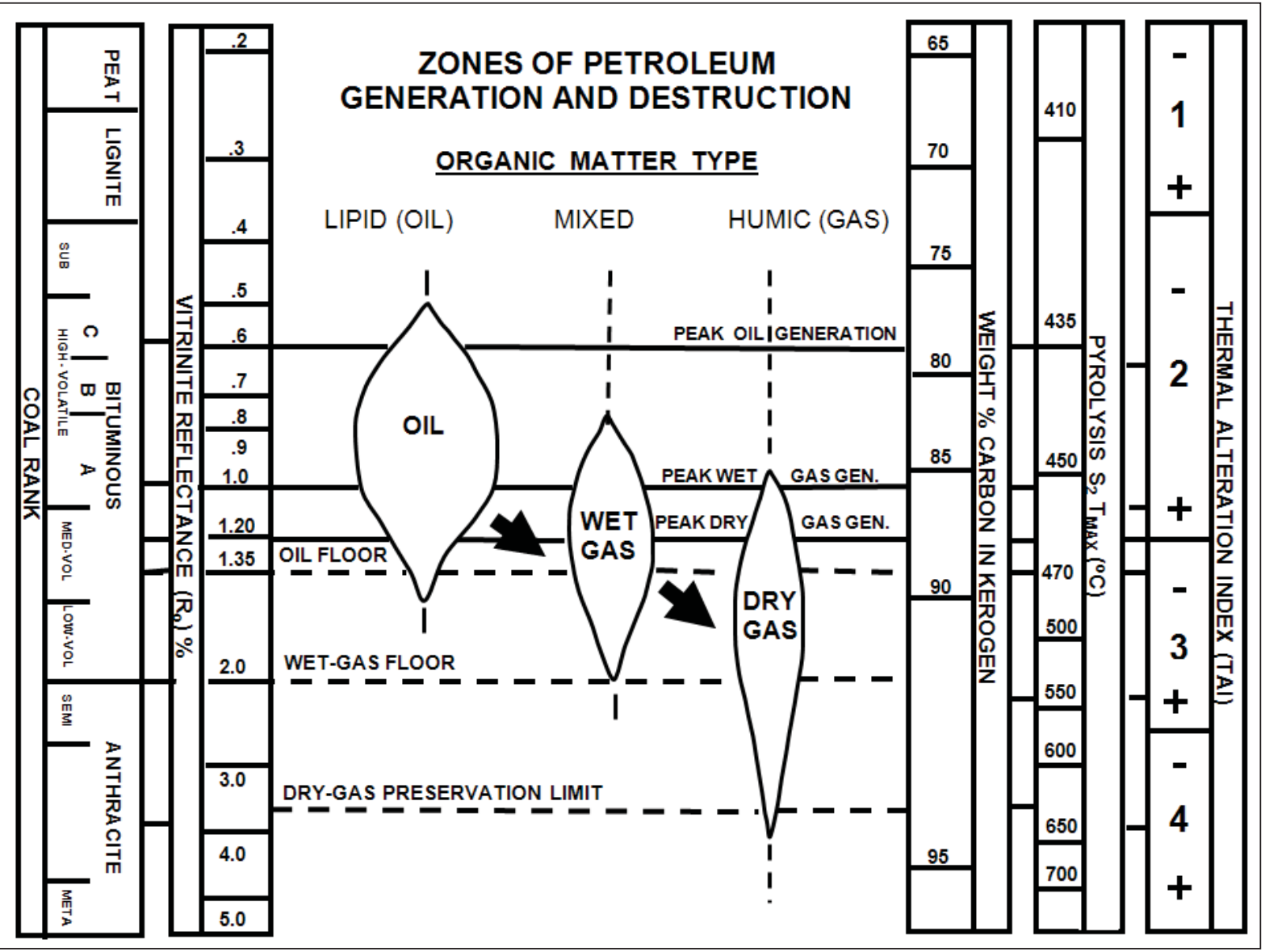

Figure 13. Diagram showing correlation of various thermal maturation indices for organic material, and zones of petroleum generation and destruction (after Wally Dow, DGSI, Inc.) 
well into the zone of dry gas generation, with vitrinite reflectance values of $>2.0$ percent $R_{o}$ (Howell and others, 1992). The geochemical data, and the stratigraphic and structural relationships of the Triassic and Jurassic rocks in the Cobblestone parautochthonous sequence suggest that these rocks had significantly less depth of burial than coeval rocks in the Colville basin, or coeval rocks exposed in thrust sheets in the Brooks Range to the south. The lower thermal maturity of the Cobblestone parautochthonous belt suggests that the Triassic and Lower Jurassic rocks were not buried under the complete section of Cretaceous rocks at the southern part of the Colville basin. We infer emplacement of the Otuk Formation and overlying Cobblestone Member of the Fortress Mountain Formation (Barremian) in this belt by thrusting and uplift coeval with deposition of the younger parts of the Fortress Mountain Formation and the Aptian-Albian Torok and Nanushuk Formations.

This belt of thermally anomalous parautochthonous rocks may have important implications for potential hydrocarbon exploration plays elsewhere along the southern part of the Brooks Range foothills belt. The trend seems to be part of a regional belt of rocks of lower thermal maturity, which may extend along the entire Arctic Slope and may separate the northern mountain front from the southern flank of the Colville basin. Similar stratigraphic and structural relationships and thermal anomalies are present in the foothills of the northwestern DeLong Mountains in the western Brooks Range (Mull and others, 2000), and in the foothills of the western Endicott Mountains in the central Brooks Range (Cole and others, 1997). These anomalous structural and stratigraphic relationships may place organic-rich oil- and gas-prone source rocks in the southern foothills belt in close proximity to potential Cretaceous reservoir rocks. These relationships seem to enhance both the gas and the oil potential of the Brooks Range foothills belt.

The presence of organic-rich Triassic and Jurassic rocks on the Endicott Mountains allochthon at the mountain front also has implications for the petroleum potential of the northern parts of the Colville basin. The presence of these rocks at the mountain front suggests that rich hydrocarbon source rocks extend under the entire north-south extent of the Colville basin. Thermal maturation of these rocks in the deeper parts of the Colville basin has probably resulted in generation and expulsion of large quantities of hydrocarbons that probably migrated north toward NPRA and the Barrow Arch (fig. 2).

\section{CRETACEOUS SOURCE ROCKS}

The Cretaceous shales and mudstones in the Cobblestone Creek-May Creek area are thick, and are typical of most of the fill of the Colville basin. Most of these shales and mudstones are relatively lean hydrocarbon source rocks. The Torok Formation (Aptian-Albian), which is more than 19,700 ft $(6,000 \mathrm{~m})$ thick in the subsurface and constitutes most of the Brookian sequence, has TOC that ranges from 0.5 percent to slightly more than 1.0 percent, and is considered a fair source rock for gas (table A1 in Appendix). The Kingak Formation (Valanginian), which is relatively thin $(200 \mathrm{ft}[60 \mathrm{~m}])$ and is exposed only in the Cobblestone parautochthonous belt, contains $<0.5$ percent TOC and is a non-source rock.

Most samples from the unnamed phosphatic-manganiferous shale unit (fig. 8), which constitutes the basal Brookian sediments, range from 1.5 percent to 2.7 percent TOC (table A1 in Appendix). Although kerogen analyses were not available at the time of writing, the unit is considered a good source rock horizon. The phosphatic-manganiferous shale is exposed only in the Cobblestone parautochthonous sequence and is relatively thin $(<230 \mathrm{ft}[70 \mathrm{~m}])$, but coeval rocks are probably present at the base of the Brookian sequence in the Colville basin. Thermal maturation of similar rocks in the deeper parts of the Colville basin probably has resulted in generation and expulsion of significant volumes of hydrocarbons that may have migrated northward toward NPRA and the Barrow Arch. 


\title{
PRELIMINARY APATITE FISSION-TRACK DATA FROM THE COBBLESTONE CREEK-MAY CREEK AREA
}

\author{
(by Paul B. O’Sullivan, Apatite to Zircon, Inc., 1075 Matson Road, Viola, Idaho 83872-9709)
}

\section{INTRODUCTION}

Apatite fission-track (AFT) results were obtained from 41 samples collected from rocks exposed within the Cobblestone Creek-May Creek map area (table A2 in Appendix). The locations from which these samples were collected are shown on fig.A1. Many of these analyses have not been published, and most were generated by the author from samples that were collected for other purposes. Following is a preliminary discussion of the AFT results as well as some preliminary interpretations of the results in terms of both inferred cooling and denudation, and structural relationships. The reader is referred to O'Sullivan $(1996,1999)$ and O'Sullivan and others (1997) for a summary and discussion of the procedures used during apatite sample processing and analysis. These reports contain numerous examples of the use of AFT analyses in constraining the thermal and tectonic history of rocks sampled across the North Slope. The discussion below represents a preliminary introduction to unpublished AFT results from samples collected from within the Cobblestone Creek and May Creek map area. These results are discussed by structural unit from south to north as delineated on the geologic map and cross section $\mathrm{A}-\mathrm{A}^{\prime}$ and on figure 14, which is modified from section A-A'. The complete analytical results of the samples discussed here, including single-grain ages and confined track length distributions, as well as detailed interpretations of the data, will be published elsewhere.

\section{RESULTS AND INTERPRETATION}

Sample information and AFT age results are presented in table A2 in Appendix. Sample information includes the geologic formation, the general sampling location, and its latitude and longitude. Also presented are each sample's AFT age and error (in $\mathrm{Ma}$ ), and $\mathrm{Chi}^{2}$ value. The $\mathrm{Chi}^{2}$ statistic tests the probability that all grains counted within an analysis belong to a single population of ages. A probability of less than 5 percent is considered evidence of a significant spread of single-grain ages, whereas a probability of greater than 90 percent is considered evidence of a very tight spread of single-grain ages, and thus a higher level of certainty in the accuracy of the age.

\section{ENDICOTT MOUNTAINS ALLOCHTHON AT MOUNTAIN FRONT}

Three AFT ages from the Endicott Mountains allochthon exposed along the mountain front range from $58 \pm 4$ to $46 \pm 3 \mathrm{Ma}$ (uncertainties are \pm 1 unless otherwise stated). The younger AFT ages of $45 \mathrm{Ma}$ are from the Upper Triassic limestone and Karen Creek members of the Otuk Formation, while the oldest AFT age of 58 Ma is from the sandstone in the Lower Mississippian Kayak Shale. All AFT ages are significantly younger than depositional ages, indicating post-depositional thermal annealing.

Interpretation of the AFT data from the Endicott Mountains allochthon suggests that the samples resided at paleotemperatures $\geq 110^{\circ} \mathrm{C}$ prior to two episodes of rapid cooling during the Cenozoic. The data from sample CLFT-16 (basal Kayak Shale) records rapid cooling from elevated paleotemperatures $\geq 110^{\circ} \mathrm{C}$ to $<60^{\circ} \mathrm{C}$ during the Paleocene at $60 \mathrm{Ma}$ (fig. 14). Subsequently, rapid cooling from elevated paleotemperatures of $\geq 110^{\circ} \mathrm{C}$ to $<60^{\circ} \mathrm{C}$ during the Eocene at $45 \mathrm{Ma}$ is recorded by samples CLFT-05 and CLFT-21 from the Triassic rocks of the mountain front.

These results indicate that: (1) the structural block containing CLFT-16 (basal Kayak Shale) was denuded rapidly during the Paleocene, and (2) the Triassic samples collected along the northern margin of the Endicott Mountains allochthon did not experience rapid denudation until the Eocene. The AFT results and structural relationships depicted in figure 14 require a significant component of Eocene thrust displacement that resulted in emplacement of the Endicott Mountain allochthon over the Picnic Creek allochthon.

\section{DISTURBED BELT-PICNIC CREEK OR IPNAVIK RIVER ALLOCHTHON}

Four apatite fission track ages have been generated from samples of the Okpikruak Formation (Kog) (Valanginian) exposed in the Peregrine Ridge anticline. The AFT ages from these samples range from $107 \pm 10$ to $64 \pm 4 \mathrm{Ma}$ (table A2 in Appendix). Three of the AFT ages are 44-68 million years younger than the Valanginian depositional age of the Okpikruak (137 to $132 \mathrm{Ma}$ ), and one sample has an AFT age that is 25 million years younger than the depositional age. AFT ages that are younger than the Okpikruak depositional age suggest that these samples were exposed to elevated paleotemperatures after deposition, which resulted in post-depositional thermal annealing. 
However, the track lengths and single-grain ages from these samples indicate that the ages were not totally reset prior to rapid Paleocene cooling. Hence, these rocks were significantly cooled and almost overprinted at $\geq 110^{\circ} \mathrm{C}$ prior to rapid cooling during the Cenozoic, which resulted in total or near total resetting of the AFT ages.

\section{DISTURBED BELT-UNNAMED MÉLANGE/OLISTOSTROME}

Five AFT ages from blocks of Okpikruak Formation in the mélange/olistostrome have AFT ages that range from $135 \pm 11$ to $142 \pm 9 \mathrm{Ma}$ and are essentially the same as or older than the Valanginian depositional age of the Okpikruak Formation (137-132 Ma) that underlies the mélange/olistostrome, which was apparently emplaced in the early Aptian. These samples apparently have remained at much cooler temperatures following deposition, which has resulted in little, if any, resetting of the AFT ages. Two representative samples (CLFT-07 from the mélange/olistostrome with a $142 \mathrm{Ma}$ AFT age that is greater than the apparent Aptian depositional age, and CLFT-08 from the Okpikruak Formation with a 64 Ma AFT age that is significantly less than depositional age) illustrate the scale of the difference between the AFT ages in the mélange/olistostrome and the underlying Okpikruak Formation. The apatite fission-track data suggest that parts of the Okpikruak Formation that were incorporated in the

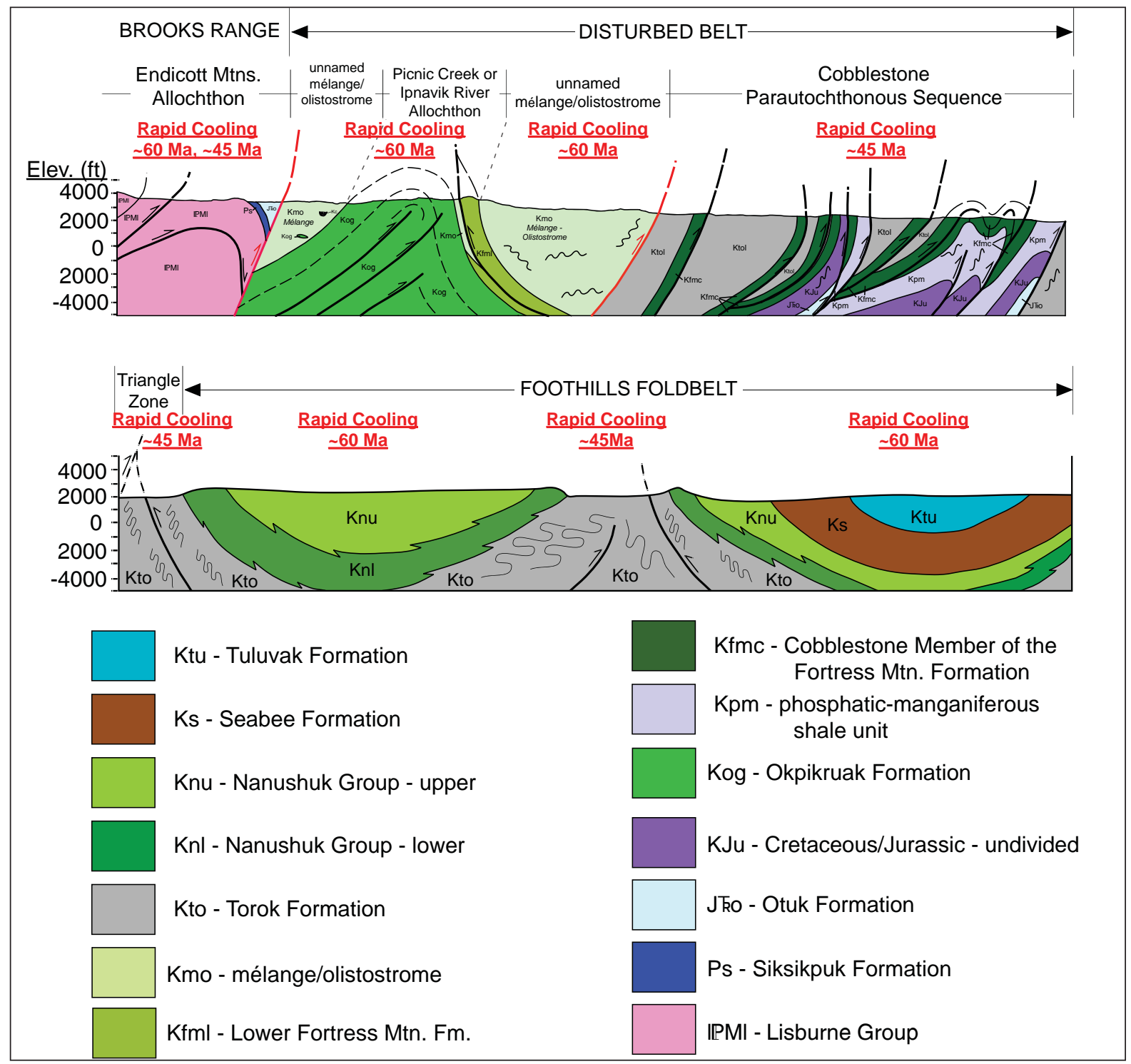

Figure 14. Cross section A-A', modified from cross section $A-A$ ', showing generalized apatite fission-track data across structural belts in Cobblestone Creek-May Creek area. 
mélange experienced relatively low post-depositional paleotemperatures, resulting in little, if any, reduction of the AFT age. In contrast, rocks deeper in the section were exposed to much higher temperatures, which resulted in significant resetting of the AFT age. Subsequently, the whole stratigraphic section must have been exposed to its maximum paleotemperatures just prior to rapid cooling of the entire section during the Paleocene. This cooling likely was the result of kilometer-scale denudation that occurred during Paleocene deformation and uplift of the Endicott Mountains.

Thermal maturity data from organic geochemical analysis of three samples of sheared mudstone from the mélange/olistostrome (table A1 in Appendix) suggest that the samples have been subjected to higher paleotemperatures than indicated by the apatite fission-track data (table A2 in Appendix). These samples yielded maximum temperature $\left(\mathrm{T}_{\text {max }}\right)$ values ranging from $482^{\circ}$ to $508^{\circ} \mathrm{C}$ and vitrinite reflectance $\left(\mathrm{R}_{\mathrm{o}}\right)$ of 2.66 , which also suggests that the mélange matrix was subjected to higher paleotemperature than indicated by the fission-track data. This apparent contradiction between the two types of data could be reconciled if the kerogen in the organic geochemical samples was recycled from older rocks that had a higher temperature thermal history. However, the kerogen data from these samples do not support the presence of recycled kerogen (DGSI, written commun., 1/11/02). The apparent contradiction between the geochemical and apatite fission-track data is unresolved.

\section{DISTURBED BELT - COBBLESTONE PARAUTOCHTHONOUS SEQUENCE}

Fourteen AFT ages have been generated from samples of the Cobblestone Member of the Fortress Mountain Formation (Aptian) collected along both Cobblestone and May creeks north of the belt of Picnic Creek allochthon and the mélange/olistostrome. The AFT ages from these samples range from $53 \pm 3$ to $44 \pm 4 \mathrm{Ma}$, and are concordant within $\pm 2 \mathrm{Ma}$ errors. These AFT ages are significantly younger than depositional ages, and indicate a significant post-depositional reduction in single-grain ages in response to thermal annealing.

The AFT data from the Cobblestone parautochthonous sequence suggest that these samples resided at paleotemperatures $\geq 110^{\circ} \mathrm{C}$ prior to an episode of rapid cooling during the Cenozoic. These results require that the Cobblestone member samples collected from throughout the Cobblestone parautochthonous sequence did not experience rapid denudation until the Eocene. In combination with the structural relationships depicted in figure 14 the AFT results suggest that a significant component of the thrust displacement that resulted in the emplacement of the Cobblestone parautochthonous sequence over the foreland basin sediments to the north must have occurred during the Eocene.

\section{FOOTHILLS FOLDBELT}

Fourteen AFT ages have been generated from samples of the Torok Formation (Aptian-Albian), the Nanushuk Formation (Albian-Cenomanian), and the Tuluvak Formation (Turonian-Coniacian) exposed in the Arc Mountain syncline and anticline and the May Creek syncline north of the triangle zone. The AFT ages from these samples range from $63 \pm 9$ to $42 \pm 6 \mathrm{Ma}$, and all are significantly younger than depositional ages, indicating a significant post-depositional reduction in single-grain ages in response to thermal annealing. However, within these data there are two major AFT age groupings that correspond with stratigraphic and structural location. In the Torok and lower Nanushuk Formations at the base of the section, AFT ages are between 48 and $42 \mathrm{Ma}$. Higher in the section within the upper Nanushuk and Tuluvak Formations all AFT ages are between 63 and $53 \mathrm{Ma}$.

The AFT data from the foothills foldbelt samples suggest that they resided at paleotemperatures $\geq 110^{\circ} \mathrm{C}$ prior to two episodes of rapid cooling during the Cenozoic. The data from samples higher in the section record rapid cooling from elevated paleotemperatures $\geq 110^{\circ} \mathrm{C}$ to $<60^{\circ} \mathrm{C}$ during the Paleocene at $60 \mathrm{Ma}$ (fig. 14). Samples from deeper in the section record subsequent rapid cooling from elevated paleotemperatures $\geq 110^{\circ} \mathrm{C}$ to $<60^{\circ} \mathrm{C}$ during the Eocene at $45 \mathrm{Ma}$.

These results suggest that: (1) initial cooling occurred during the Paleocene in response to rapid denudation, and (2) a second episode of recorded cooling occurred in response to rapid denudation during the Eocene. Based on these AFT results a significant component of the overall denudation must have occurred during the Paleocene event, but subsequent Eocene deformation was responsible for formation of the triangle zone, and for a significant amount of folding of the May Creek and Arc Mountain structures. 


\section{DESCRIPTION OF MAP UNITS}

\section{SURFICIAL DEPOSITS}

Unconsolidated deposits were interpreted from 1:63,360-scale aerial photographs, augmented by limited field observations made during traverses while mapping bedrock units, and by aerial reconnaissance. Published mapping by Hamilton (1978) served as a guide for interpretation of surficial deposits.

Qa Alluvium, undifferentiated (Quaternary) - Silt, sand, and gravel deposited in active river and stream channels; rivers typically braided. Unit includes abandoned channels and floodplain deposits that may be mantled by fluvial silt overbank deposits and low terraces that locally support sparse populations of dwarf willows.

Qc Colluvium (Quaternary) - Active talus deposits on steep valley walls, composed of angular blocky material derived from bedrock; and fine-grained deposits of reworked silt, sand, and pebble gravel found on gentle slopes as apron-like features.

Qgm Glacial Moraine DePosits (Quaternary) — Poorly sorted, unstratified till ranging from clayey, stony silt to sandy, bouldery gravel; contains large erratic boulders in some places; forms distinct vegetated, nested, concentric, recessional moraines on the east side of the Nanushuk River valley, and subdued knob and kettle topography with numerous small lakes in the northeastern part of the map area on the west side of the Itkillik River valley. Includes deposits of Anaktuvuk River, Sagavanirktok River, and Itkillik glaciations.

Qgm (Ks) - Glacial moraine deposits overlying the Seabee Formation.

Qgm (Kn) - Glacial moraine deposits overlying the Nanushuk Formation.

Qgm (Ktou) - Glacial moraine deposits overlying the upper Torok Formation.

Qu Quaternary Deposits, undifferentiated (Quaternary)—Includes fine-grained colluvium, upland silt deposits, and other surficial material not otherwise differentiated; dominantly in lowland areas, mostly mantled by tundra.

Qu (Ktu) - Undifferentiated colluvium and tundra cover overlying the Tuluvak Formation

Qu (Ks) - Undifferentiated colluvium and tundra cover overlying the Seabee Formation

Qu (Kn) - Undifferentiated colluvium and tundra cover overlying the Nanushuk Formation.

Qu (Knu) - Undifferentiated colluvium and tundra cover overlying the upper Nanushuk Formation.

Qu (Knl) - Undifferentiated colluvium and tundra cover overlying the lower Nanushuk Formation.

Qu (Kto)-Undifferentiated colluvium and tundra cover overlying the Torok Formation

Qu (Ktou) - Undifferentiated colluvium and tundra cover overlying the upper Torok Formation

\section{DEPOSITS OF THE COLVILLE BASIN FOLDBELT}

The foredeep deposits of the Colville basin underlie the northern half of the map area, north of the Tuktu escarpment. This sequence of rocks represents deposition on a northeastwardly prograding deltaic shelf.

Ktu Tuluvak Formation (revised nomenclature, Mull and others, 2003; Turonian to Coniacian) —Sandstone and conglomerate in two relatively resistant intervals up to $80 \mathrm{ft}(25 \mathrm{~m})$ thick that form mesa-like uplands with locally resistant ledges or rounded benches on hillsides in May Creek syncline at the north end of the map area. Sandstone is clean, well sorted, fine to medium grained, $>95$ percent well-rounded quartz, friable, contains low-angle cross-bedding, probably dominantly marine; in May Creek syncline sandstone has $>20$ percent porosity and $>800$ md permeability. Conglomerate consists of conspicuously well rounded, well sorted pea gravel to small pebble clasts of white quartz and black chert with no matrix but with conspicuous drusy quartz on grain surfaces, well exposed locally in a 33-ft-thick (10-m-thick) ledge on the south flank of the May Creek syncline. The lower part of the Tuluvak, which consists of sandstone, siltstone, and interbedded shales, formerly mapped as part of the Ayiyak Member of the Seabee Formation (Detterman and others, 1963), is not exposed in the map area but is exposed in bluffs on the west bank of the Nanushuk River on the south flank of May Creek syncline $1 \mathrm{mi}(1.6 \mathrm{~km})$ west of the map area. 
Thickness: $<460 \mathrm{ft}(140 \mathrm{~m})$

Age: Turonian to Coniacian (Mull and others, 2003)

Ks Seabee Formation (revised nomenclature, Mull and others, 2003; Cenomanian to Turonian)—Dominantly soft, organic-rich black shale, with bentonite interbeds and some thin, silicified tuff beds; underlies broad, tundra-covered valley of May Creek on the north flank of Arc Mountain anticline, mostly tundra covered in the map area; the upper part of the unit is partly exposed in a bluff on the west bank of the Nanushuk River on the south flank of May Creek syncline $1 \mathrm{mi}(1.6 \mathrm{~km})$ west of the map area.

Thickness: Estimated 1,200 ft (360 m)

Age: Cenomanian to Turonian (Mull and others, 2003; table A2 in Appendix).

Nanushuk Formation (Albian to Cenomanian; Mull and others, 2003)

The Nanushuk Group (Formation) is a thick, clastic succession originally defined on the central Arctic Slope by Gryc and others (1956). It is characterized by two regionally mappable generalized units: (1) a basal interval of dominantly marine sandstones gradationally overlain by (2) marginal-marine to nonmarine sandstones, conglomerates, and coals. These broad, mappable genetic units previously were termed the Tuktu and Chandler Formations on the central Arctic Slope (Detterman and others, 1964), and Kukpowruk and Corwin Formations on the western Arctic Slope (Chapman and Sable, 1960). However, subsequent workers (Ahlbrandt and others, 1979; Huffman and others, 1985; Mull, 1985) have not used these names because of the difficulty in delineating a consistent and meaningful mappable boundary between the two units. Mull and others (2003) have redefined the collective unit as the Nanushuk Formation, in places composed of informal upper and lower units that are dominantly nonmarine and dominantly marine, respectively.

The upper Nanushuk is here distinguished from the lower Nanushuk by a lower sand:shale ratio, the presence of coal seams, carbonaceous shale, a greater abundance of plant remains, a general absence of marine fossil fauna, and a higher percentage of iron-weathering products. Sediments of the upper Nanushuk record a dominantly fluvial environment with episodes of marginal-marine and occasional marine inundation, which are transitional with the dominantly marine sediments of the lower Nanushuk. The lower Nanushuk records a complex history of overall progradation of deltaic and shallow-marine depositional environments onto a storm-dominated shelf. In the map area, the upper Nanushuk is exposed in the axis of Arc Mountain syncline where it forms intermittent resistant ledges with less persistent bedding traces than in the lower Nanushuk, which has a higher sand:shale ratio. As a result of its higher sand:shale ratio and generally more laterally persistent sandstones, the lower Nanushuk forms the more resistant, elevated flanks of Arc Mountain anticline and the Tuktu escarpment. In this map area, an arbitrary boundary between upper and lower Nanushuk is drawn at a position above which persistent marine sandstone beds appear to be relatively uncommon within the overlying dominantly marginal-marine to nonmarine section. In the northern part of the east-central Brooks Range foothills, north of the Cobblestone Creek map area, the nonmarine part of the formation is not present, and the Nanushuk consists almost entirely of marine or marginal marine deposits.

Knu Nanushuk Formation, upPer unit (Albian to Cenomanian) - Sandstone, medium gray to yellowish brown, fine to coarse grained, thin to medium bedded lithic and chert arenite, and local conglomerate and conglomeratic sandstones; forms resistant beds and rubble traces. Interbedded recessive rocks, which make up the greater thickness of beds, consist of dark gray silty shale, clay shale, black carbonaceous shale, siltstone, and local coal beds. Sand consists dominantly of quartz and chert, with lesser amounts of calcite, feldspar, and lithic fragments. Conglomerate clasts are predominantly sub-rounded pebbles and cobbles of white quartz and black, gray, greenish gray, and maroon chert, and local ironstone, coal, gray sandstone, quartzite, argillite, and mafic igneous rocks. Generally upward-fining and upward-thinning successions show plane-parallel lamination, tabular sets of planar and inclined cross-stratification, asymmetrical ripple cross-lamination and bedforms, trough cross-bedding, and basal channel scours. Sandstone and siltstone beds are lenticular and pinch and grade laterally to shale. Conglomerate is commonly exposed as large- 
scale multilateral and/or multistory channel fills. The lower part of the unit contains a well-exposed log jam of petrified wood and wood imprints in an exposure on the south flank of Arc Mountain anticline on the east bank of the Nanushuk River (SW1/4, Sec. 19, T9S, R7E). Sandstones are generally tight, with measured porosity $<11$ percent, with an average of about 5 percent, and permeability $<1$ md (Ahlbrandt and others, 1979). The top of the Nanushuk Formation is not exposed in the map area; the base of the upper Nanushuk interfingers with the lower Nanushuk. Includes rocks formerly named Grandstand and Ninuluk Formations, and Killik and Niakogon Tongues of the Chandler Formation.

Thickness: 1,475-1,650 ft (450-500 m) (D.L. LePain, oral communication, 2002) Age: Albian to Cenomanian (Detterman and others, 1963)

Knl Nanushuk formation, LOWER unit (Albian) - Sandstone, light to medium to yellowish gray, fine to medium grained, generally thin to medium bedded lithic arenite. Contains interbedded dark gray, fissile to silty shale, medium to dark gray siltstone, and carbonaceous shale. In the map area, closely spaced and laterally persistent dark yellowish brown weathering lower Nanushuk sandstone beds form prominent resistant ridges that flank the Arc Mountain anticline and form the Tuktu escarpment. Sandstones consist dominantly of quartz and chert, with lesser amounts of calcite, feldspar, and lithic fragments. Upwardcoarsening and -thickening successions are capped by sandstones with a variety of sedimentary structures, including plane-parallel lamination, current- and wave-ripple bedforms, large- and small-scale trough cross-stratification, hummocky cross-stratification, and swaley cross-stratification. Biogenic structures are locally common and include Teichichnus, Diplocraterion, Rhizocorallium, Planolites, and Paleophycos, among others (D.L. LePain, written communication, 2000; LePain and Kirkham, 2001). Locally contains common marine pelecypods, coalified plant fragments, and plant impressions. Upward intertonguing of marine and marginal-marine to nonmarine sediments marks transition to the upper Nanushuk. Sandstones are generally tight, with porosity $<10$ percent and permeability $<1 \mathrm{md}$ (Ahlbrandt and others, 1979).

The base of the Nanushuk is gradational and intertongues with the underlying recessive shales of the Torok Formation; contact is mapped at the base of the lowest laterally persistent sandstone trace visible on aerial photographs, but is exposed in stream cutbanks on the south flank of the Arc Mountain anticline on the east side of the Nanushuk River, and on the north flank of the Arc Mountain anticline at May Creek. Includes rocks formerly named Tuktu Formation.

Thickness: $\sim 600 \mathrm{ft}(\sim 180 \mathrm{~m})$ (D.L. LePain, oral communication, 2002)

Age: Albian (Detterman and others, 1963)

Ktou Torok Formation, upper part (Aptian-Albian or Albian) - Silty mudstone and minor shale, dark gray, interbedded with medium gray siltstone and minor amounts of medium gray to tan fine-grained sandstone. Silty mudstone is thin bedded and finely laminated, has characteristic nodular fracture. Interbedded siltstone and sandstone is thin to medium bedded, with platy to blocky fracture; contains graded bedding, wave- and current-ripple bedforms, sole markings, load casts, shale ripups, horizontal burrows, and scattered carbonaceous plant fragments. Sandstone beds are most common in the upper parts of the formation and appear to lack lateral continuity. The unit is a thick slope to prodelta deposit and is gradational and intertongues with both overlying and underlying units. The Torok is relatively incompetent and is generally poorly exposed; it acts as a detachment surface for decollement folding of the overlying competent Nanushuk Formation. The upper part of the unit forms lowlands in the axis of the Arc Mountain anticline and on the south side of the Tuktu escarpment.

Thickness: Greater than 19,700 $\mathrm{ft}(6,000 \mathrm{~m})$, based on seismic data, but the base not exposed in the northern part of the map area.

Age: Aptian-Albian or Albian (Patton, 1956; table A2 in Appendix). 


\section{DEPOSITS OF THE DISTURBED BELT}

\section{COBBLESTONE PARAUTOCHTHONOUS SEQUENCE}

The Cobblestone parautochthonous sequence is exposed in a 6- to 8-mi-wide (9.5- to 13-km-wide) belt across the central part of the map area. It consists of a relatively thin distinctive sequence of rocks imbricated by thrust faults.

Ktol Torok Formation, LOWER Part (Aptian or Aptian-Albian; Patton, 1956) - Generally similar to the upper part of the Torok in the northern part of the map area; consists dominantly of dark gray, silty mudstone, interbedded with medium gray siltstone and minor amounts of medium gray to tan fine-grained sandstone. Silty mudstone is thin bedded and finely laminated, has characteristic nodular fracture. Interbedded siltstone and sandstone is thin to medium bedded, with platy to blocky fracture; contains graded bedding, waveand current-ripple bedforms, sole markings, load casts, shale ripups, horizontal burrows, and scattered carbonaceous plant fragments. In the Cobblestone parautochthonous sequence, the unit is generally poorly exposed in swales between fault-bounded ridges of the Cobblestone Member of the Fortress Mountain Formation; it appears to conformably and gradationally overlie the Cobblestone Member. The top of the unit is not present in the Cobblestone parautochthonous sequence.

One locality within the Cobblestone triangle zone on May Creek just north of Cobblestone ridges is anomalous; it consists of $650 \mathrm{ft}(200 \mathrm{~m})$ of gray, hard, lithic, fine to very fine grained, light to medium gray micaceous sandstone in thin beds to 6 in $(15 \mathrm{~cm})$ thick, grading upward to finer-grained sandstone beds interbedded with soft, gray, clayey, fissile, micaceous shale containing Aptian-Albian microfauna, and minor silty mudstone. Sandstones are lighter gray and cleaner than typical Torok, Cobblestone, or Fortress Mountain sandstones; gray sandstone and soft micaceous clay shale are uncharacteristic of Torok Formation elsewhere. One sandstone bed has a sweet, gassy odor.

Thickness: Greater than 1,640 ft (500 m), based on interval thickness between thrust sheets in the southern part of the Cobblestone parautochthonous sequence.

Age: Aptian or Aptian-Albian, probably mostly Aptian; micropaleontological data from both foraminifera and palynomorphs from several localities within the belt yields a variety of Lower Cretaceous ages ranging from probable Aptian-Albian to possible Hauterivian or Valanginian (table A2 in Appendix).

Kfmc Cobblestone Member of Fortress Mountain Formation (Barremian? to Aptian; revised nomenclature) - The Cobblestone sandstone unit (informal name; Kelley, 1990) was named for a lithic sandstone and conglomerate unit that is well exposed in the Cobblestone Creek area. Previous workers (Patton and Tailleur, 1964) mapped the unit and overlying and underlying mudstones as Fortress Mountain Formation. However, the Cobblestone sandstone and associated rocks are thought by most workers to be older than, and stratigraphically beneath, the main complex of Fortress Mountain Formation, which is typically much thicker than the Cobblestone sandstone and contains numerous thick conglomerate beds. Although lithic sandstones in the Cobblestone unit are commonly similar to those in the Fortress Mountain Formation, in most locations compositional characteristics can be used to distinguish the Cobblestone sandstones from the Fortress Mountain Formation.

We here redefine the Cobblestone sandstone unit as the Cobblestone Member of the Fortress Mountain Formation. This designation shows the affinity of these rocks to the Fortress Mountain Formation, but also indicates that there are significant mappable characteristics that allow the unit to be distinguished from other parts of the Fortress Mountain Formation.

The Cobblestone Member characteristically consists of light to medium gray weathering, fine to medium grained lithic sandstone, minor chert pebble conglomerate, siltstone, and mudstone. Pebble to cobble conglomerate is present locally. A conspicuous characteristic of the sandstone is an abundance of light tan to cream weathering leached chert grains that commonly are present as granules and give a light-colored 
appearance to the otherwise dark-colored lithic sandstone. Flakes and small elongate granules of tasmanite, a distinctive black organic-rich shale, also are common in some beds, and were probably derived from the Ipnavik River allochthon. The sandstone beds are characterized by graded bedding and commonly consist of amalgamated turbidites that form units up to $13 \mathrm{ft}(4 \mathrm{~m})$ thick interbedded with mudstones. Coarser-grained sandstones and conglomerate units commonly appear to have been deposited as debris flows, and regional facies distribution of Cobblestone beds suggest that chaotic debris-flow deposits are more abundant to the south. At one well-exposed locality on the Nanushuk River, the unit contains $\sim 100$ $\mathrm{ft}(\sim 30 \mathrm{~m})$ of poorly sorted greenish gray lithic sandstone, matrix-supported conglomerate, and breccia in beds to $6.5 \mathrm{ft}(2 \mathrm{~m})$ thick gradationally overlain by dark gray to black silty mudstone and shale. These coarser-grained beds are probably debris-flow deposits.

Just east of the Itkillik River, $6 \mathrm{mi}(9.7 \mathrm{~km})$ east of the map area, the southernmost exposure of the Cobblestone Member contains abundant pebble to cobble conglomerate and carbonaceous mudstone beds deposited as debris flows, and in one locality contains an elongate, 6.5 -ft-long (2-m-long) block of sandstone. The top of the unit is overlain by the Torok Formation at a relatively sharp contact; the basal contact with underlying unnamed phosphatic-manganiferous shale is also sharp.

Thickness: $\sim 200 \mathrm{ft}(65 \mathrm{~m})$

Age: Barremian? to Aptian based on stratigraphic position and a sparse microfauna (table A2 in Appendix)

Kpm UnNamed Phosphatic-Manganiferous shale (Barremian) - Hard, bioturbated shale with conspicuous reddish brown, manganiferous weathering sheen. Grades upward into dark gray silty mudstone with manganiferous sheen. The upper contact with the Cobblestone sandstone is relatively sharp; basal contact is not exposed. This unit represents initial Brookian deposition into the southern portion of the Colville basin.

Thickness: Estimated $250 \mathrm{ft}$ (75 m)

Age: Probably Barremian based on stratigraphic position and sparse faunal data (table A2 in Appendix)

KJu Undivided Cretaceous AND JuRAssic Rocks-Dominantly gray to black shale and mudstone, structurally contorted, exposed at two localities on the south side of Cobblestone ridges (the east bank of Cobblestone Creek and in a tributary of May Creek), includes rock units too thin to delineate at the scale of the map and cross section:

Kpm-Unnamed phosphatic-manganiferous shale (Lower Cretaceous, Barremian)—Hard, bioturbated shale with conspicuous reddish brown, manganiferous weathering sheen, $\sim 65 \mathrm{ft}(\sim 20 \mathrm{~m})$;

Kc - Buchia limestone coquina (Valanginian)—see description below;

KJk-Kingak shale (Lower Cretaceous, Valanginian) — Gray, silty shale with large ovoid ironstone concretions, structurally deformed, $\sim 165 \mathrm{ft}(\sim 50 \mathrm{~m})$ exposed, Valanginian age based on microfaunal data (table A2 in Appendix);

Job-Blankenship Member of Otuk Formation (Lower to lower Upper Jurassic, Pliensbachian to Oxfordian) - Organic-rich black fissile shale and paper shale with a few thin bentonite seams, contains scattered small $(0.2$ in $[0.5 \mathrm{~cm}]$ diameter) pelecypod Otapiria tailleuri; contorted, $\sim 100 \mathrm{ft}(\sim 30 \mathrm{~m})$ exposed; excellent oil and gas source rock, contains beds with $>14$ percent total organic carbon. Age is based on microfaunal data (table A2 in Appendix); the unit represents condensed deposition coeval with the lower part of the Kingak Shale in the northern Colville basin.

Kc Buchia limestone coquina (Valanginian) —Distinctive reddish brown weathering, thin-bedded limestone $<6.5 \mathrm{ft}(<2 \mathrm{~m})$ thick, interbedded with Kingak Shale, in beds 0.8 to 3.9 in $(2$ to $10 \mathrm{~cm})$ thick, with thin interbeds and partings of dark gray to black fissile shale, composed entirely of the pelecypod Buchia sublaevis (Valanginian). The unit is a distinctive, important, often conspicuous marker unit commonly referred to as "the coquinoid limestone," but is too thin to be shown at map scale on either map or cross section; exposures are indicated by small fossil icon and formation symbol. 
Thickness: Undeformed stratigraphic thickness unknown, but probably $<33 \mathrm{ft}(<10 \mathrm{~m})$; commonly structurally contorted, $\sim 10 \mathrm{ft}(\sim 3 \mathrm{~m})$ exposed at the Cobblestone Creek and May Creek localities.

Age: Valanginian, based upon age of Buchia sublaevis sp. (Jones and Grantz, 1964).

Jko Oтuk Formation (Upper Triassic to lower Upper Jurassic [Oxfordian])-The Triassic lower part of the formation, informally known as the limestone member ( $\mathrm{kol}$ ), is exposed within the Cobblestone parautochthonous sequence in two small, but very significant, localities on the west bank and in a small gully on the east side of May Creek north of the Cobblestone ridges. A third exposure of the Otuk is also reported to be present in a tributary of May Creek on the south side of the Cobblestone ridges (W.K. Wallace, pers. commun.). The unit consists of thinly interbedded, fossiliferous, black, organic-rich limestone and shale with $>6$ percent total organic carbon; contains abundant flat Upper Triassic pelecypods Monotis sp. and Halobia sp., overlain by a 3.3-ft-thick (1-m-thick) interval of shale and 3.9-in-thick (10-cm-thick) glauconitic siltstone correlative with Karen Creek Sandstone ( $\mathrm{kkc}$ ) and Sag River Sandstone. The Triassic part of the formation is more limey and less siliceous than the Otuk Formation on the Endicott Mountains allochthon at the mountain front, and has characteristics of Shublik Formation in the subsurface of the North Slope. The limestone member is overlain by the lower part of the Blankenship Member (Job; Lower to lower Upper Jurassic), which consists of several feet (a few meters) of organic-rich black marl and fissile paper shale with up to 6 percent total organic carbon. The Blankenship Member contains scattered small $(0.2$ in $[0.5 \mathrm{~cm}]$ diameter) pelecypod Otapiria tailleuri and represents condensed deposition coeval with the lower part of the Kingak Shale of the northern Colville basin.

Thickness: $<330 \mathrm{ft}(<100 \mathrm{~m})$

Age: Upper Triassic (Mull and others, 1982), and Lower Jurassic (Pliensbachian) to lower Upper Jurassic (Oxfordian) in Blankenship Member, based on presence of pelecypod Otapiria tailleuri sp. and microfaunal data (table A2 in Appendix).

\section{ALLOCHTHONOUS ROCKS}

\section{Syntectonic turbidites, mélange, and olistostromal deposits}

Kmo UnNamed mélange/olistostrome unit (Lower Cretaceous, post-Valanginian, Aptian?) —Dark-gray to black mudstone locally sheared to a scaly argillite, and thin-bedded dark gray to black turbidites; the unit contains large sheared exotic blocks and elongate masses up to $330 \mathrm{ft}(100 \mathrm{~m})$ long of conspicuously white weathering, partly leached chert, greenish-gray chert, and silicified mudstone of the Imnaitchiak Chert (JPi) probably locally derived from Ipnavik River or Picnic Creek allochthon (see below). South of Peregrine Ridge anticline, the unit contains masses of Okpikruak graywacke containing Buchia sublaevis (Valanginian), and blocks of Buchia limestone coquina (Kc; Valanginian) derived from the top of the underlying Endicott Mountains allochthon (see below). The unit appears to be intensely deformed and structurally thickened, and is interpreted to be a large-scale mass-transport deposit gravitationally transported basinward from an area of active tectonics. However, the unit also contains blocks that appear to have been tectonically sheared in the process of emplacement in the mudstone/scaly argillite groundmass. The unit appears to disconformably overlie Okpikruak Formation on the south flank of Peregrine Ridge anticline and to be folded around the faulted southwestern plunge of the anticline. On the north side of Peregrine Ridge anticline, the unit disconformably overlies rocks interpreted as lower Fortress Mountain Formation ( $\mathrm{Kfml})$. The unit contains five blocks of graywacke with apatite fission-track ages of 135-144 Ma (table 2 in Appendix), which suggests that this mélange/olistostrome may not have been deeply buried since its deposition. The unit forms a lowland area in valleys of Peregrine, Cobblestone, and May creeks north of the mountain front and north of Peregrine Ridge anticline. East of Cobblestone Creek, it trends laterally eastward into thinly bedded graywackes and mudstone of the lower part of the Fortress Mountain Formation (Kfml; see below).

Thickness: Unknown

Age: Lower Cretaceous, post-Valanginian, probably Aptian?; post-Valanginian age of deposit based on presence of blocks of sheared lithified Buchia limestone coquina (Kc) and blocks of Okpikruak Formation (Kog) containing Buchia sublaevis (Valanginian) incorporated in mélange. 
Kfml Fortress Mountain Formation, LOWer part (Lower Cretaceous, Aptian?)—Prominent vertical, resistant, ridge-forming unit $\sim 50 \mathrm{ft}(\sim 15 \mathrm{~m})$ thick on the north flank of Peregrine Ridge anticline, well exposed on Peregrine Creek. The unit consists of poorly sorted polymict cobble to boulder conglomerate and breccia probably deposited as debris flows. Clasts consist of chert, mafic igneous rocks, gabbro, granitic rocks, limestone, and quartzitic sandstone. In good exposures along Peregrine Creek, the unit apparently grades upward into a sequence of finer-grained graywacke sandstones and interbedded silty mudstones that thin and fine upward, and into thick, silty mudstone/shale containing conspicuous ovoid yellowish brown weathering concretions characteristic of lower Fortress Mountain Formation in Atigun Gorge east of the map area and in Thumbprint syncline in the Siksikpuk River area west of map area. The base of the unit on Peregrine Ridge is a thrust fault (probable out-of-syncline backthrust) overlying elongate masses of Imnaitchiak Chert (JPi), silty mudstone, fine-grained sandstone, and Buchia limestone coquina (Kc) in a thin section of the unnamed mélange/olistostrome (Kmo) disconformably overlying Okpikruak Formation (Kog) on the north flank of Peregrine Ridge anticline. Kfml unit does not appear to be present on the south flank of Peregrine Ridge anticline.

In lowland areas east of Cobblestone Creek the unit is mostly rubble consisting of thinly bedded, fine grained, dark greenish gray graywacke interbedded with dark gray to black mudstone; it resembles the lower part of the Fortress Mountain Formation in Atigun Gorge east of the map area. The unit appears to be structurally contorted. Unless bounded by an unrecognized fault, the upper part of the unit appears to be a lateral equivalent of mélange/olistostrome $(\mathrm{Kmo})$ west of Cobblestone Creek.

Thickness: Unknown

Age: uncertain, probably Aptian

Kc Buchia Limestone coquina (Valanginian) — Reddish brown weathering, thin-bedded limestone $<6.5 \mathrm{ft}$ $(<2 \mathrm{~m})$ thick, consisting of individual coquina beds 0.8 to 3.9 in $(2$ to $10 \mathrm{~cm})$ thick composed entirely of the pelecypod Buchia sublaevis (Valanginian), commonly referred to as "the coquinoid limestone unit." The unit occurs in mélange as sheared blocks derived from the top of the Endicott Mountains allochthon. The unit's reddish brown weathering character is often conspicuous, but the unit is too thin to be shown at map scale on either map or cross section; locations of exposures are indicated by a small fossil icon and formation symbol.

JPi Imnaitchiak Chert (Pennsylvanian to Jurassic) — Light gray to greenish gray to yellowish orange weathering, thin- to thick-bedded chert and silicified mudstone with interbedded siliceous shale; white chert is commonly leached. In the map area, the unit is present only as structurally contorted elongate exotic blocks up to $330 \mathrm{ft}(100 \mathrm{~m})$ long in the mélange/olistostrome unit, abundant in the area between Cobblestone Creek and Cascade Creek on the north and south sides of Peregrine Ridge anticline. The unit commonly weathers yellowish orange to brownish gray, but the area of Cascade Creek to Cobblestone Creek north of Peregrine Ridge anticline contains many large masses that weather light gray to white and form conspicuous rubble patches on hillsides.

Thickness: Unknown

Age: Pennsylvanian to Jurassic, based on radiolarian data (Mull and others, 1987)

\section{Picnic Creek or Ipnavik River Allochthon}

Kog OKPIKruak Formation, graywacke facies (Lower Cretaceous, Valanginian)—Dominantly dark greenish gray, thin to thick bedded, fine- to medium-grained lithic graywacke and siltstone with rhythmically interbedded black mudstone and shale, deposited as turbidites; weathers dark gray to black. The unit forms the tightly folded and faulted Peregrine Ridge anticline that underlies highland ridges between Cascade Creek and May Creek, and is well exposed and isoclinally folded in Peregrine Creek valley. Contains beds of Buchia limestone coquina (Kc; the coquinoid limestone) and black shale interbedded between lithic sandstone units (W.K. Wallace, pers. commun., July 2007). 
Thickness: Estimated 2,300-3,300(?) ft (700-1,000[?] m)

Age: Valanginian, based on presence of Buchia limestone coquina interbedded with graywackes on Cobblestone Creek (W.K. Wallace, pers. commun.)

Koqg OKpikruak Formation, quartzose graywacke facies (Lower Cretaceous, Berriasian, or Valanginian) Dominantly dense, resistant, light gray to greenish gray, medium to thick bedded, fine- to medium-grained quartzose graywacke, possibly tuffaceous, with minor amounts of interbedded sheared black shale. Some beds contain abundant black shale or carbonaceous flakes and light gray leached chert granules; some graywacke beds are finely micaceous and contain load and groove casts and burrowing. Many beds have abundant conspicuous dark healed microfractures resulting in a characteristic spiderweb-like appearance on fresh surfaces. The unit weathers to form conspicuously light gray resistant bluffs and high ridges in contrast to typical dark gray weathering character of other facies of the Okpikruak Formation. The unit is present at only one locality on the Nanushuk River at the west edge of the map area, but is widespread forming upland ridges in the Kanayut River map area to the west.

Thickness: Unknown

Age: Lower Cretaceous, Berriasian or Valanginian, inferred

\section{DEPOSITS OF THE BROOKS RANGE MOUNTAIN FRONT ENDICOTT MOUNTAINS ALLOCHTHON}

Kc Buchia limestone coquina (Lower Cretaceous, Valanginian) - Reddish brown weathering limestone coquina composed entirely of the pelecypod Buchia sublaevis sp., in beds 0.8 to 4 in $(2$ to $10 \mathrm{~cm})$ thick, interval $<16 \mathrm{ft}(<5 \mathrm{~m})$ thick but commonly structurally contorted and thickened or missing from the stratigraphic sequence. In a few localities the unit is interleaved with Kingak Shale and Otuk Formation, but most commonly is found as resistant exotic tectonic blocks in the southern part of the mélange/olistostrome. The unit is a distinctive, often conspicuous, important marker horizon commonly referred to as "the coquinoid limestone," but is too thin to be shown at the scale of the map or cross section; location of outcrops are indicated by a small fossil icon and formation symbol.

Thickness: $<16 \mathrm{ft}(<5 \mathrm{~m})$

Age: Valanginian, based on age of pelecypod Buchia sublaevis (Jones and Grantz, 1964)

J ko Otuk Formation (Middle Triassic to lower Upper Jurassic, Oxfordian)—-Interbedded fossiliferous black chert, limestone, and organic-rich black sooty shale in four lithogenetic units: (1) a basal, poorly exposed shale member - black organic shale (Middle Triassic); (2) the "chert" member-black silicified mudstone, limestone, and shale (Middle and Upper Triassic); (3) the limestone member-thinly interbedded shale and thin-bedded black and light gray banded limestone and silicified limestone commonly with abundant pelecypods Monotis and Halobia sp., that weathers yellowish tan (Upper Triassic); and (4) at the top, the Blankenship Member - organic-rich black shale, marl, and thin bedded chert; represents condensed deposition (Lower and lower Upper Jurassic). The Formation is generally structurally contorted and not well exposed; the best exposures are on Cobblestone Creek and May Creek at the mountain front.

Thickness: $<330 \mathrm{ft}(<100 \mathrm{~m})$

Age: Middle and Upper Triassic, chert and limestone members (Mull and others, 1982), and Lower to lower Upper Jurassic (Oxfordian), Blankenship Member (table A2 in Appendix).

Ps Siksikpuk Formation (Permian) - Dominantly greenish gray claystone and siltstone in the map area; contains scattered barite and siderite nodules; the unit is incompetent and generally intensely deformed, and exposed only in stream cuts and a few hillside localities at the mountain front between the Nanushuk River and May Creek.

Thickness: $<330 \mathrm{ft}(<100 \mathrm{~m})$

Age: Permian, based upon megafaunal data (Patton, 1957). 
PMI Lisburne Group (Upper Mississippian to Lower Pennsylvanian)—Dominantly massive, light gray weathering, cliff-forming crinoidal limestone and dolomite; in places it contains abundant black chert nodules, lenses, and beds; the unit contains distinctive sooty black phosphatic shale and limestone in the upper part; it locally contains leached pinpoint to vugular porosity filled with solid hydrocarbon. The unit is exposed in a series of folded thrust sheets forming the northern flank of the Endicott Mountains; this structure is not mapped in detail south of the mountain front.

Thickness: $>1,640 \mathrm{ft}(>500 \mathrm{~m})$

Age: Upper Mississippian, Meramecian to Lower Pennsylvanian, Atokan

Mk Kayak Shale (Lower Mississippian) - Dark gray to black fissile clay shale with yellowish brown weathering, thin, fossiliferous limestone beds near the top; commonly contains conspicuous reddish brown weathering nodules. In the map area, the unit is exposed only in the core of a tight anticlinal nose of Lisburne Group limestone on the west side of the Itkillik River valley at the east edge of the map area. The base of the unit contains quartzitic sandstone beds transitional with underlying Kanayut Conglomerate, which is extensively exposed south of the map area.

Thickness: Probably $<330 \mathrm{ft}(<100 \mathrm{~m})$ thick

Age: Lower Mississippian

\section{REFERENCES CITED}

Ahlbrandt, T.S., ed., 1979, Preliminary geologic, petrologic, and paleontologic results of the study of Nanushuk Group rocks, North Slope, Alaska: U.S. Geological Survey Circular C-794, 163 p.

Bodnar, D.A., 1989, Stratigraphy of the Otuk Formation and a Cretaceous coquinoid limestone and shale unit, north-central Brooks Range, Alaska, in Mull, C.G., and Adams, K.E., eds., Dalton Highway, Yukon River to Prudhoe Bay, Alaska: Bedrock geology of the eastern Koyukuk Basin, central brooks Range, and east-central Arctic Slope: Alaska Division of Geological \& Geophysical Surveys Guidebook 7, v. 2, p. 277-284.

Bowsher, A.L., and Dutro, J.T., Jr., 1949, Preliminary report on the Mississippian rocks of the Kanayut, Itkillik, and Nanushuk Lakes area, Alaska: U.S. Geological Survey Investigations of Naval Petroleum Reserve \#4 and adjacent areas, Report 24.

Cole, F., Bird., K.J., Toro, J., Roure., F., O’Sullivan, P.B., Pawlewicz, M., and Howell., D.G., 1997, An integrated model for the frontal Brooks Range and Colville basin $250 \mathrm{~km}$ west of the Trans-Alaska Crustal Transect: Journal of Geophysical Research, v. 102, no. B9, p. 20,685-20,708.

Detterman, R.L., Bickel, R.S., and Gryc, George, 1963, Geology of the Chandler River region, Alaska: U.S. Geological Survey Professional Paper 303-E, p. 233-324.

Fuis, G.S., Murphy, J.M., Lutter, W.J., Moore, T.E., Bird, K.J., and Christensen, N.I., 1997, Deep seismic structure and tectonics of northern Alaska-Crustal scale duplexing with deformation extending into the upper mantle: Journal of Geophysical Research, v. 102, no. B9, p. 20,873-20,896.

Hamilton, T.D., 1979, Surficial geologic map of the Chandler Lake quadrangle, Alaska: U.S. Geological Survey Miscellaneous Field Studies map MF 1121, 1 sheet, scale 1:250,000.

Harris, E.E., Delaney, P.R., Mull, C.G., LePain, D.L., and Burns, P.A., 2009, Geologic map of the Kanayut River area, Chandler Lake Quadrangle, Alaska: Alaska Division of Geological \& Geophysical Surveys Preliminary Interpretive Report, 1 sheet, scale 1:63,360 in press.

Harris, E.E., Mull, C.G., Reifenstuhl, R.R., and Montayne, Simone, 2002, Geologic map of the Dalton Highway (Atigun Gorge to Slope Mountain) area, southern Arctic Foothills, Alaska: Alaska Division of Geological \& Geophysical Surveys Preliminary Interpretive Report 2002-2, 1 sheet, scale 1:63,360.

Howell, D.G., Bird, K.J., Huafu, Lu, and Johnsson, Mark J., 1992, Tectonics and petroleum potential of the Brooks Range fold and thrust belt - A progress report, in Bradley, D.C., and Ford, A.B., eds., Geologic Studies in Alaska by the U.S. Geological Survey, 1990: U.S. Geological Survey Bulletin 1999, p. 112-126.

Hubbard, R.J., Edich, S.P., and Rattey, R.P., 1987, Geologic evolution and hydrocarbon habitat of the Arctic Alaska microplate, in Tailleur, I.L., and Weimer, Paul, eds., Alaskan North Slope Geology: Society of Economic Paleontologists and Mineralogists, Pacific Section, and Alaska Geological Society, p. 797-830. 
Huffman, A.C., Jr., 1985, Geology of the Nanushuk Group and related rocks, North Slope, Alaska: U.S. Geological Survey Bulletin 1614, $129 \mathrm{p}$.

Jones, D.L., and Grantz, Arthur, 1964, Stratigraphic and structural significance of Cretaceous fossils from Tiglukpuk Formation, northern Alaska: American Association of Petroleum Geologists Bulletin, v. 68, no. 9, p. $1,462-1,474$.

Kelley, J.S, 1984, Geologic map of a portion of the Chandler Lake B-1 quadrangle, Alaska: U.S. Geological Survey Open-File Report 88-77, 3 sheets, scale 1:63,360.

1988, Preliminary geologic map of the Chandler Lake quadrangle, Alaska: U.S. Geological Survey OpenFile Report 88-42, 2 sheets, scale 1:125,000.

1989, Draft generalized geologic map of the Chandler Lake quadrangle, north-central Alaska: U.S. Geological Survey Open-File Report 89-495, 31 p., 1 sheet, scale 1:250,000.

LePain, D.L., and Kirkham R., 2001, Potential reservoir facies in the Nanushuk Formation (Albian-Cenomanian), central North Slope, Alaska - Examples from outcrop and core, in Houseknecht, D.W., ed., NPRA Core Workshop-Petroleum Plays and Systems in the National Petroleum Reserve-Alaska: SEPM Core Workshop no. 21, p.19-36.

Lerand, Monti, 1973, Beaufort Sea, in McCrossan, R.G., ed., Future Petroleum Provinces of Canada-Their Geology and Potential: Canadian Society of Petroleum Geologists, Memoir 1, p. 315-386.

Mayfield, C.F., Tailleur, I.L., and Ellersieck, I., 1988, Stratigraphy, structure and palinspastic synthesis of the western Brooks Range, northwestern Alaska in Gryc, George, ed., Geology and exploration of the National Petroleum Reserve in Alaska, 1974 to 1982: U.S. Geological Survey Professional Paper 1399, p. 143-186.

Micropaleo Consultants, Inc., (Haga, Hideyo, and Mickey, Michael), 2000, Chandler Lake-NPRA project, Biostratigraphy report; 37 outcrop and subsurface samples, 1999, North Slope field party, Alaska: Unpublished report prepared for Alaska Division of Geological \& Geophysical Surveys.

2000, Chandler Lake-NPRA project, Biostratigraphy report: 33 outcrop samples, 2000 and 2002 North Slope field parties, Brooks Range, Alaska: Unpublished report prepared for Alaska Division of Geological \& Geophysical Surveys, January 30, 2003.

Moore, T.E., Wallace, W.K., Bird, K.J., Karl, S.M., Mull, C.G., and Dillon, J.T., 1994, Geology of northern Alaska, in Plafker, G., and Berg, H.C., eds., The geology of Alaska: Geological Society of America, The Geology of North America, v. G.1. p. 49-140.

Mull, C.G., 1979, Nanushuk Group deposition and the Late Mesozoic structural evolution of the central and western Brooks Range and Arctic Slope, in Ahlbrandt, T.S., ed., Preliminary geologic, petrologic, and paleontologic results of the study of Nanushuk Group rocks, North Slope, Alaska: U.S. Geological Survey Circular C-794, p. $5-13$.

1985, Cretaceous tectonics, depositional cycles, and the Nanushuk Group, Brooks Range and the Arctic Slope, Alaska, in Huffman, A.C., Jr. ed., 1985, Geology of the Nanushuk Group and related rocks, North Slope, Alaska: U.S. Geological Survey Bulletin 1614, p. 7-36.

1989, Generalized stratigraphy and structure of the Brooks Range and Arctic Slope, in Mull, C.G., and Adams, K.E., eds., Dalton Highway, Yukon River to Prudhoe Bay, Alaska-Bedrock geology of the eastern Koyukuk Basin, central Brooks Range, and east-central Arctic Slope: Alaska Division of Geological \& Geophysical Surveys, Guidebook 7, v. 1, p. 31-46.

Mull, C.G., Moore, T.E., Harris, E.E., and Tailleur, I.L., 1994, Geologic map of the Killik River quadrangle, Brooks Range, Alaska: U.S. Geological Survey Open-file Report 94-679, 1 sheet, scale 1:125,000.

Mull, C.G., Glenn, R.K., and Adams, K.E., 1997, Tectonic evolution of the central Brooks Range mountain front: Evidence from the Atigun Gorge region: Journal of Geophysical Research, v. 102, no. B9, p. 20,749-20,773.

Mull, C.G., Houseknecht, D.W., and Bird, K.J., 2003, Revised Cretaceous and Tertiary stratigraphic nomenclature in Colville basin, northern Alaska: U.S. Geological Survey Professional Paper 1673, 51 p. (available online at the U.S. Geological Survey website: http://pubs.usgs.gov/pp/p1673/).

Mull, C.G, Houseknecht, D.W., and Pessel, G.H., and Garrity, C.P., 2004, Geologic map of the Umiat quadrangle, Alaska: U.S. Geological Survey Scientific Investigations Map 2817-A, scale 1:250,000 (available online at http://pubs.usgs.gov/sim/2004/2817a/).

Mull, C.G., Moore, T.E., Harris, E.E., and Tailleur, I.L., 1996, Geologic map of the Killik River quadrangle, central Brooks Range, Alaska: U.S. Geological Survey Open-File Map 94-679, scale 1:125,000. 
Mull, C.G., Harris, E.E., Reifenstuhl, R.R., and Moore, T.E., 2000, Geologic map of the Coke Basin-Kukpowruk River area, DeLong Mountains D-2 and D-3 quadrangles, northwestern Alaska: Alaska Division of Geological \& Geophysical Surveys Report of Investigations 2000-2, 1 sheet, scale 1:63,360.

Mull, C.G., Crowder, R.K., Adams, K.E., Siok, J.P., Bodnar, D.A., Harris, E.E., Alexander, R.A., and Solie, D.N., 1987, Stratigraphy and structural setting of the Picnic Creek allochthon, Killik River quadrangle, central Brooks Range, Alaska: A summary, in Tailleur, I.L., and Weimer, Paul, eds., North Slope Geology: Society of Economic Paleontologists and Mineralogists, Pacific Section, and Alaska Geological Society, p. 649-662.

O'Sullivan, P.B., 1996, Late Mesozoic and Cenozoic thermal-tectonic evolution of the North Slope foreland basin, Alaska, in Johnsson, M.J., and Howell, D.G., eds., Thermal evolution of sedimentary basins in Alaska: U.S. Geological Survey Bulletin 2142, p. 45-79.

1999, Thermochronology, denudation, and variations in paleosurface temperature-A case study from the North Slope foreland basin, Alaska: Basin Research, v. 11, no. 3, p. 191-205.

O'Sullivan, P.B., Murphy, J.M., and Blythe, A.E., 1997, Late Mesozoic and Cenozoic thermotectonic evolution of the central Brooks Range and adjacent North Slope Foreland Basin, Alaska-Including fission track results from the Trans-Alaska Crustal Transect (TACT): Journal of Geophysical Research, v. 102, p. 20,821-20,845.

Patton, W.W., Jr., 1957, A new upper Paleozoic formation, central Brooks Range, Alaska: U.S. Geological Survey Professional Paper 303-B, p. 40-45.

Patton, W.W., Jr., and Keller, A.S., 1950, Preliminary report on the stratigraphy and structure of the upper Nanushuk-Siksikpuk rivers area: U.S. Geological Survey Investigations of Naval Petroleum Reserve \#4 and adjacent areas, Preliminary Report 30, 20 p.

Patton, W.W., Jr., and Keller, A.S., 1951, Stratigraphy and structure of the upper Siksikpuk-Nanushuk rivers area, Alaska: U.S. Geological Survey Investigations of Naval Petroleum Reserve \#4 and adjacent areas, Regular Report 42, 20 p.

Patton, W.W., Jr., and Tailleur, I.L., 1964, Geology of the Killik-Itkillik region, Alaska: U.S. Geological Survey Professional Paper 303-G, p. 409-500, scale 1:125,000.

Peapples, P.R., Wallace, W.K., Wartes, M.A., Swenson, R.F., Mull, C.G., Dumoulin, J.A., Harris, E.E., Finzel, E.S., Reifenstuhl, R.R., and Loveland, A.M., 2007, Geologic map of the Siksikpuk River area, Chandler Lake Quadrangle, Alaska: Alaska Division of Geological \& Geophysical Surveys Preliminary Interpretive Report 2007-1, 1 sheet, scale 1:63,360.

Pessel, G.H., and Mull, C.G., 1964, Geologic map of the Chandler Lake quadrangle: Richfield Oil Corporation (Atlantic Richfield Company) unpublished mapping, by permission of Phillips Alaska, Inc., scale 1:250,000.

Sonneman, H.S., and Mull, C.G., 1972, Geologic map of the Chandler Lake quadrangle: Exxon Company, USA, unpublished mapping, by permission of Exxon Co., USA, scale 1:125,000.

Webber, E.J., and Detterman, R.L., 1947, Preliminary report on the stratigraphy of the area of the Nanushuk River, Alaska: U.S. Geological Survey Investigations of Naval Petroleum Reserve \#4 and adjacent areas, Report \#48p, 7 p, 2 sheets. 
Appendix Figure A1. Station location map for analytical samples, appendix tables A1 and A2.

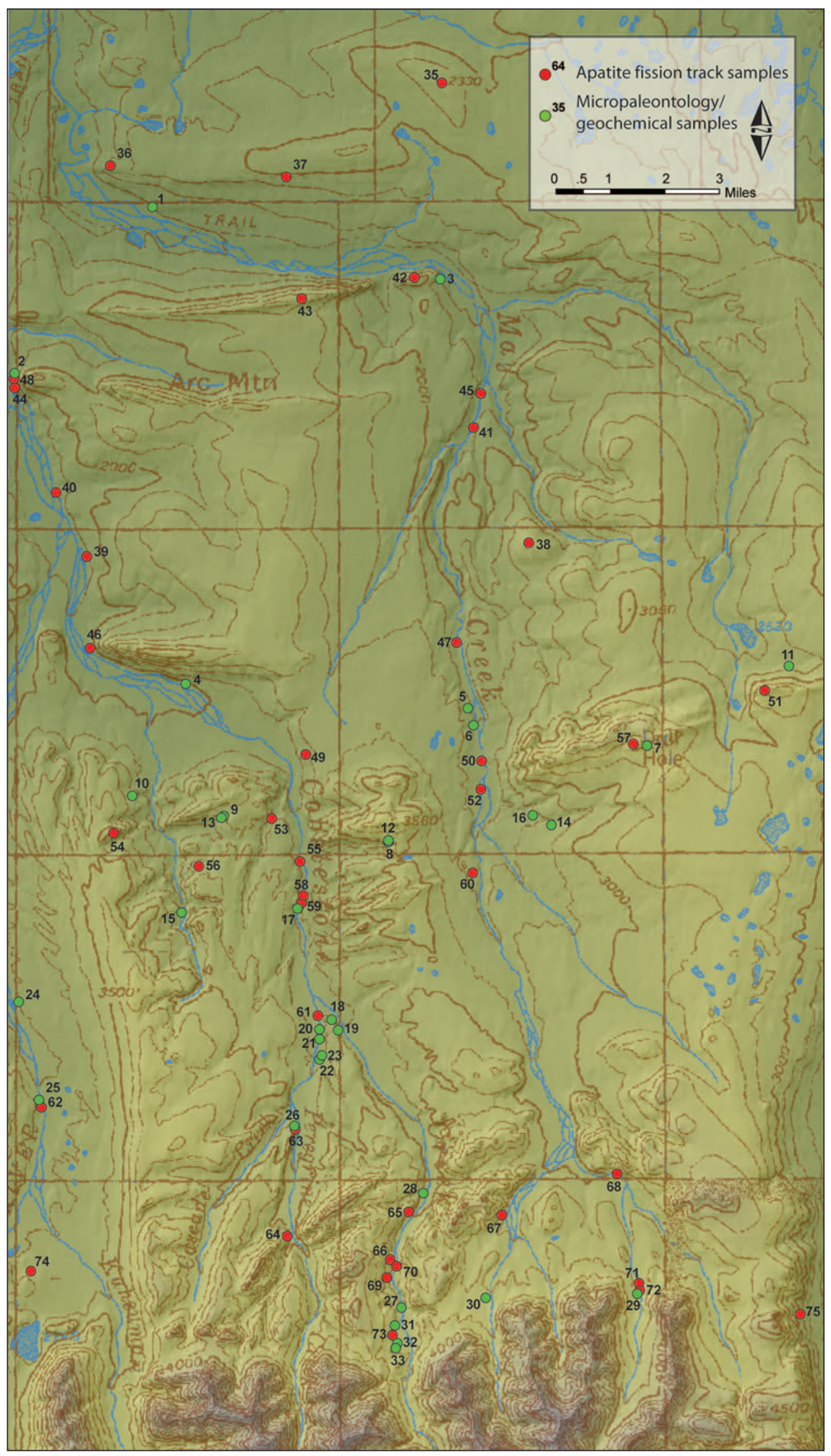




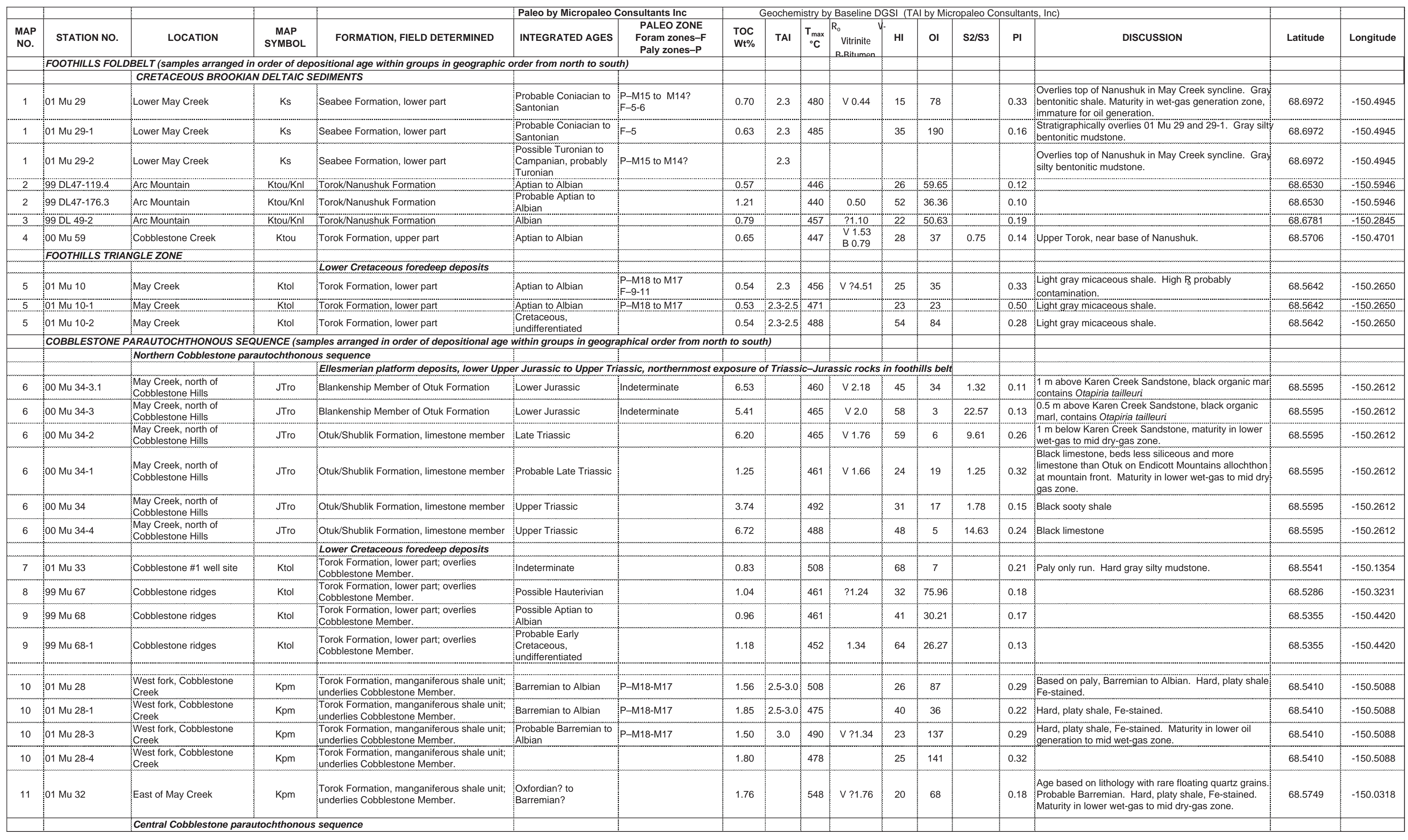


Appendix Table A1. Selected micropaleontology and organic geochemical data from Cobblestone Creek-May Creek area-continued.

\begin{tabular}{|c|c|c|c|c|c|c|c|c|c|c|c|c|c|c|c|c|c|}
\hline $\begin{array}{l}\text { MAP } \\
\text { NO. }\end{array}$ & STATION NO. & LOCATION & $\begin{array}{l}\text { MAP } \\
\text { SYMBOL }\end{array}$ & FORMATION, FIELD DETERMINED & INTEGRATED AGES & $\begin{array}{l}\text { PALEO ZONE } \\
\text { Foram zones-F } \\
\text { Paly zones-P }\end{array}$ & $\begin{array}{l}\text { Toc } \\
\text { wto }\end{array}$ & TAI & 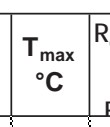 & $\begin{array}{l}R_{0} \\
\text { Vitrinite } \\
\text { REititman }\end{array}$ & W & ol & s2/S3 & PI & DISCUSSION & Latitude & Longitude \\
\hline & & & & Lower Cretaceous foredeep deposits & & & & & & & & & & & & & \\
\hline 12 & $99 \mathrm{Mu} 67$ & Cobblestone ridges & Ktol & $\begin{array}{l}\text { Torok Formation, lower part; overlies } \\
\text { Cobblestone Member. }\end{array}$ & Possible Hauterivian & & 1.04 & & 461 & $? 1.24$ & 31.7 & 75.96 & & 0.18 & & 68.5290 & -150.3230 \\
\hline 13 & $99 \mathrm{Mu} 68$ & Cobblestone ridges & Ktol & $\begin{array}{l}\text { Torok Formation, Iower part; overlies } \\
\text { Cobblestone Member. }\end{array}$ & Possible Aptian-Albian & & 0.96 & & 461 & & 40.6 & 30.21 & & $|0.17|$ & & 68.5350 & -150.4440 \\
\hline 13 & $99 \mathrm{Mu} 68-1$ & Cobblestone ridges & Ktol & $\begin{array}{l}\text { Torok Formation, lower part; overlies } \\
\text { Cobblestone Member. }\end{array}$ & $\begin{array}{l}\text { Probabble Early } \\
\text { Cretaceous, } \\
\text { undifferentiated }\end{array}$ & & 1.18 & & 452 & 1.34 & 63.6 & 26.27 & & 0.13 & & 68.5350 & -150.4440 \\
\hline 14 & $00 \mathrm{Mu} 25$ & $\begin{array}{l}\text { May Creek tributary, } \\
\text { Cobblestone Hills area }\end{array}$ & Ktol & $\begin{array}{l}\text { Torok Formation, Iower part; overlies } \\
\text { Cobblestone Member. }\end{array}$ & Lower Cretaceous & Indeterminate & 2.77 & & 505 & B ?1.51 & 18 & 25 & & 0.31 & Underlies Cobblestone Member. & 68.5330 & -150.2045 \\
\hline 15 & $85 \mathrm{Mu} 71$ & West Cobblestone Creek & Ktol & $\begin{array}{l}\text { Torok Formation, lower part; overlies } \\
\text { Coobblestone Member. }\end{array}$ & Aptian? to Albian & & 0.94 & & 455 & 0.96 & 51 & 19 & & 0.17 & & 68.5100 & -150.4727 \\
\hline & & & & Ellesmerian platform deposits, Lower Cr & taceous (Valanginian) to & o upper Triassic & & & & & & & & & & & \\
\hline 16 & 85 Mu 79-3 & $\begin{array}{l}\text { May Creek tributary, } \\
\text { Cobblestone Hills }\end{array}$ & $\mathrm{KJu}$ & Kingak Formation, coquinoid limestone & Valanginian & & 0.37 & & 444 & $? 0.11$ & 35 & 19 & 0.24 & 0.24 & $R_{0}$ data probably erroneous. & 68.5356 & -150.2180 \\
\hline 16 & $00 \mathrm{Mu} 26$ & $\begin{array}{l}\text { May Creek tributary, } \\
\text { Cobblestone Hills }\end{array}$ & KJu & Kingak Formation & Valanginian & $F-13 b$ & 0.22 & & 422 & V 1.43 & 45 & 6 & 0.71 & 0.23 & Gray silty shale & 68.5356 & -150.2180 \\
\hline 16 & $00 \mathrm{Mu} 26-1$ & $\begin{array}{l}\text { May Creek tributary, } \\
\text { Cobblestone Hills }\end{array}$ & KJu & Kingak Formation & Valanginian & $F-13 b$ & 0.24 & & 481 & & 21 & 6 & 0.56 & $0.17 \mathrm{C}$ & Gray silty shale & 68.5356 & -150.2180 \\
\hline 16 & 00 Mu 26-2 & $\begin{array}{l}\text { May Creek tributary, } \\
\text { Cobblestone Hills }\end{array}$ & KJu & Blankenship Member of Otuk Formation & Probable Valanginian & $\begin{array}{l}\text { F-13b } \\
\text { P-M20 }\end{array}$ & 0.90 & & 490 & & 11 & 6 & 0.77 & 0.38 & & 68.5356 & -150.2180 \\
\hline 16 & $00 \mathrm{Mu} 26-3$ & $\begin{array}{l}\text { May Creek tributary, } \\
\text { Cobblestone Hills }\end{array}$ & KJu & Blankenship Member of Otuk Formation & Early Jurassic & Indeterminate & 4.08 & & 457 & & 61 & 6 & 10.78 & 0.12 & Fissile, black organic shale & 68.5356 & -150.2180 \\
\hline 16 & $00 \mathrm{Mu} 26-3.1$ & $\begin{array}{l}\text { May Creek tributary, } \\
\text { cobblestone Hills }\end{array}$ & KJu & Blankenship Member of Otuk Formation & Early Jurassic & Indeterminate & 2.43 & & 461 & & 45 & 5 & 8.38 & 0.16 & Fissile, black organic shale & 68.5356 & -150.2180 \\
\hline 16 & $00 \mathrm{Mu} 26-3.2$ & $\begin{array}{l}\text { May Creeet tributary, } \\
\text { Cobblestone Hills }\end{array}$ & KJu & Blankenship Member of Otuk Formation & Early Jurassic & Indeterminate & 2.17 & & 461 & B ?1.55 & 47 & 7 & 6.38 & $0.18 \mathrm{f}$ & Fissile, black organic shale & 68.5356 & -150.2180 \\
\hline 17 & $82 M u 67-3$ & Cobblestone Creek & KJu & Kingak Formation, coquinoid limestone & Valanginian & & 0.30 & & 385 & & 10 & 77 & 0.63 & 0.63 & & 68.5110 & -150.3889 \\
\hline 17 & 99 Mu 44-B & Cobblestone Creek & $\mathrm{KJu}$ & Kingak Formation, coquinoid limestone & Valanginian & $\begin{array}{l}\text { F-13b } \\
\text { P-M20 }\end{array}$ & 0.22 & & $\begin{array}{ll}422 \\
321\end{array}$ & V ?1.77 & 23 & & & & $\begin{array}{l}\text { Brownish-gray fissile shale interbedded with coquinoid } \\
\text { limestone. }\end{array}$ & 68.5110 & -150.3889 \\
\hline 17 & 99 Mu 44-A & Cobblestone Creek & KJu & Kingak Formation & Valanginian & $\begin{array}{l}\text { F-13b } \\
\text { P-M20 }\end{array}$ & 0.26 & & 487 & V?1.04 & 38 & & & & $\begin{array}{l}\text { Gray sitty shale with floating chert pebble and frosted } \\
\text { guartz grains; overlies coquinoid limestone }\end{array}$ & 68.5110 & -150.3889 \\
\hline 17 & $01 \mathrm{Mu} 9-6$ & Cobblestone Creek & KJu & Kingak Formation & Probable Valanginian & $\begin{array}{l}\text { F-130 } \\
\text { P-M20 }\end{array}$ & 0.43 & 3.0 & 530 & & 35 & 37 & & 0.38 & $\begin{array}{l}\text { Good forams and paly; dark gray silty shale. Maturity in } \\
\text { middle of oil generation zone. }\end{array}$ & 68.5110 & -150.3889 \\
\hline 17 & $01 \mathrm{Mu} 9-5$ & Cobblestone Creek & $\mathrm{KJu}$ & Kingak Formation & Probable Valanginian & $\begin{array}{l}\text { F-13b } \\
\text { P-M20 }\end{array}$ & 0.41 & 3.0 & 492 & & 124 & 90 & & 0.19 & Good forams and paly; dark gray silty shale & 68.5110 & -150.3889 \\
\hline 17 & 01 Mu 9-4 & Cobblestone Creek & KJu & Blankenship Member of Otuk Formation & $\begin{array}{l}\text { Probable Aalenian to } \\
\text { Oxtordian? }\end{array}$ & $F-16 b-17$ & 7.28 & & 444 & B ?1.06 & 271 & 5 & & 0.05 & $\begin{array}{l}\text { Forams lean to Aalenian, paly Mid to Late Jurassic. } \\
\text { Hard, } \mathrm{H} \text { - stained with interbedded paper shale. Source } \\
\text { rock in lower middle oil generation zone. }\end{array}$ & 68.5110 & -150.3889 \\
\hline 17 & 01 Mu 9-3 & Cobblestone Creek & KJu & Blankenship Member of Otuk Formation & Possible Oxfordian & P-M22 & 14.47 & $\begin{array}{l}2.5- \\
3.0 ?\end{array}$ & 441 & В ?0.97 & 266 & 2 & & 0.02 & $\begin{array}{l}\text { Paly possiblity Oxtordian. Yellow-orange bentonitic } \\
\text { interval with clay hhale. Source rock in mid oil } \\
\text { geneneration zone. }\end{array}$ & 68.5110 & -150.3889 \\
\hline 17 & 01 Mu 9-2 & Cobblestone Creek & KJu & Blankenship Member of Otuk Formation & Indeterminate & & 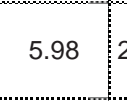 & $2.3-2.5$ & 446 & B ?1.22 & 220 & 4 & & 0.06 & $\begin{array}{l}\text { Black, fissile clay shale with thin yellow bentonite(?) fill } \\
\text { on surfaces. Source rock, in lower oil generation to mid } \\
\text { wet-gas zone. }\end{array}$ & 68.5110 & -150.3889 \\
\hline 17 & $01 \mathrm{Mu} 9-1$ & Cobblestone Creek & KJu & Blankenship Member of Otuk Formation & $\begin{array}{l}\text { Probable Aalenian to } \\
\text { Oxtordian }\end{array}$ & $F-16 b-17$ & 5.88 & $3-3.5$ & 446 & B ?1.24 & 226 & 2 & & 0.04 & $\begin{array}{l}\text { Paly poorly preserved, probably Aalenian to Oxfordian } \\
\text { forams. Black, fisisile paper shale. Source rock in } \\
\text { lower oil generation to mid wet-gas zone. }\end{array}$ & 68.5110 & -150.3889 \\
\hline 17 & $01 \mathrm{Mu} 9$ & Cobblestone Creek & KJu & Blankenship Member of Otuk Formation & Aalenian to Oxfordian & & 4.07 & 3-3.5 & 446 & $\begin{array}{ll}\mathrm{V} & ? 1.12 \\
\mathrm{~B} ? 1.13\end{array}$ & 167 & 3 & & 0.04 & $\begin{array}{l}\text { Aalenian to oxtordian torams. Paly indeterminate } \\
\text { Black, fissile clay shale with thin yellow bentonite ?? fill } \\
\text { on surfaces. Source rock in lower oil generation to } \\
\text { upper wet-gas zone. }\end{array}$ & 68.5110 & -150.3889 \\
\hline$\frac{17}{17}$ & $\begin{array}{l}99 \mathrm{Mu} \mathrm{44-1} \\
99 \mathrm{Mu} 44-1.1\end{array}$ & $\begin{array}{l}\text { Cobblestone Creek } \\
\text { Cobblestone Creek }\end{array}$ & $\frac{\mathrm{KJu}}{\mathrm{KJJu}}$ & $\begin{array}{l}\text { Blankenship Member of Otuk Formation } \\
\text { Blankenship Member of Otuk Formation }\end{array}$ & $\begin{array}{l}\text { Lower Jurassic } \\
\text { Lower Jurassic }\end{array}$ & & $\frac{10.12}{6.74}$ & & $\begin{array}{ll}459 \\
444\end{array}$ & $\frac{1.17}{V ? 1.67}$ & $\frac{201}{158}$ & 6.82 & & 0.12 & Fissile, black organic shale & $\begin{array}{l}68.5110 \\
68.5110 \\
\end{array}$ & $\begin{aligned}-150.3889 \\
-150.3889\end{aligned}$ \\
\hline 17 & $02 \mathrm{Mu} 7$, Cobble & ne creek measured se & ankensh & Member same section as 01 Mu 9 to 9-5, & $\begin{array}{l}\text { Letowervursssic } \\
\text { atigraphically underlies } 01 \\
01\end{array}$ & 1 Mи 9-6, 99 Mи 44, & 32 Mu 67 & & & & & & SI/TOC & & 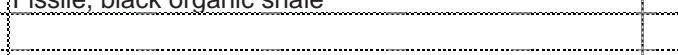 & & \\
\hline 17 & $02 \mathrm{Mu} 7-65 \mathrm{ft}$ & Cobblestone Creek & KJu & Kingak Shale & Valanginian & $\begin{array}{l}\mathrm{P}-\mathrm{M} 20 \\
\mathrm{~F}-13 \mathrm{~b}\end{array}$ & 0.53 & $3.0+$ & 484 & V 1.07 & 38 & 13 & 2.90 & 0.28 & $\begin{array}{l}\text { Gray sitty mudstone, approximately same horizon as } 0 \\
\text { Mu } 9 \text {-5. Outer neritic to upper bathyal (outer shelf to } \\
\text { upper slope). }\end{array}$ & 68.5110 & -150.3889 \\
\hline 17 & $02 \mathrm{Mu} 7-57 \mathrm{ft}$. & Cobblestone Creek & KJu & Blankenship Member of Otuk Formation & Indeterminate & & 9.35 & 3.0 & 443 & V 0.98 & 226 & 3 & 81.42 & 0.05 & $\begin{array}{l}\text { Approximately same horizon as } 01 \text { Mu 9-4. Black, } \\
\text { fissilie, paper shale, source rock in the mid oil } \\
\text { generation zone. }\end{array}$ & 68.5110 & -150.3889 \\
\hline 17 & $02 \mathrm{Mu} 7-54 \mathrm{ft}$. & Cobblestone Creek & KJu & Blankenship Member of Otuk Formation & $\begin{array}{l}\text { Probable Mississippian } \\
\text { to Late Jurassic, } \\
\text { undififerentiated }\end{array}$ & & 6.76 & 3.0 & 443 & V ?0.92 & 202 & 1 & 136.50 & 0.06 & $\begin{array}{l}\text { Black, fissile, organic-rich paper shale with Fe-stained } \\
\text { cherty interbeds, source rock in the mid oil generation } \\
\text { zone. }\end{array}$ & 68.5110 & -150.3889 \\
\hline 17 & Mu $7-51 \mathrm{ft}$ & Cobblestone Creek & KJu & Blankenship Member of Otuk Formation & Indeterminate & & 7.15 & 3.0 & 445 & & 184 & 7 & 26.30 & .10 & As above; source rock in the mid oil generation zone. & 68.5110 & 150.38 \\
\hline
\end{tabular}


Appendix Table A1. Selected micropaleontology and organic geochemical data from Cobblestone Creek-May Creek area—continued

\begin{tabular}{|c|c|c|c|c|c|c|c|c|c|c|c|c|c|c|c|c|c|}
\hline $\begin{array}{l}\text { MAP } \\
\text { NO. }\end{array}$ & STATION NO. & LOCATION & $\begin{array}{l}\text { MAP } \\
\text { SYMBOL }\end{array}$ & FORMATION, FIELD DETERMINED & INTEGRATED AGES & $\begin{array}{c}\text { PALEO ZONE } \\
\text { Foram zones-F } \\
\text { Paly zones-P }\end{array}$ & $\begin{array}{l}\text { Toc } \\
\text { Wto }\end{array}$ & TAI & $\begin{array}{c}T_{\max } \\
{ }^{\circ} C^{2}\end{array}$ & $\begin{array}{l}R_{0} \\
\text { Vitrinite } \\
\text { ReRituman }\end{array}$ & HI & ol & s2/s3 & PI & DISCUSSION & Latitude & Longitude \\
\hline 17 & $02 \mathrm{Mu} 7-48 \mathrm{ft}$. & Cobblestone Creek & KJu & Blankenship Member of Otuk Formation & $\begin{array}{l}\text { Possible Jurassic, } \\
\text { undifferentiated }\end{array}$ & & 13.51 & 3.0 & 445 & $\vee ? 0.96$ & 246 & 5 & 51.23 & 0.04 & $\begin{array}{l}\text { As above; approximately same horizon as } 011 \mathrm{Mu} \mathrm{9-3;} \\
\text { source rock in the mid oi generatiton zone. }\end{array}$ & 68.5110 & -150.3889 \\
\hline 17 & $02 \mathrm{Mu} 7-45 \mathrm{ft}$. & Cobblestone Creek & KJu & Blankenship Member of Otuk Formation & $\begin{array}{l}\text { Oxfordian to } \\
\text { Kimmeridgian }\end{array}$ & $\begin{array}{l}\text { P-M22? to M21 } \\
\text { F-16a to } 16 b\end{array}$ & 3.56 & 3.0-3.5 & 440 & & 152 & 4 & 36.07 & 0.05 & $\begin{array}{l}\text { Light gray to brownish-gray bentonitic shale/clay-stone } \\
\text { ivth scattered Fe-weathering zones, source rock in the } \\
\text { mid oil generation zone. Middle neric to upper bathyal } \\
\text { (middle shelf to upper slope). }\end{array}$ & 68.5110 & -150.3889 \\
\hline 17 & $02 \mathrm{Mu} 7-42 \mathrm{ft}$. & Cobblestone Creek & KJu & Blankenship Member of Otuk Formation & \begin{tabular}{|l} 
Oxfordian to \\
Kimmeridgian \\
\end{tabular} & $\begin{array}{l}\text { P-M22? to M21 } \\
\text { F-16a to } 16 \mathrm{~b}\end{array}$ & 4.06 & $3.0-3.5$ & 440 & B ?0.99 & 161 & 5 & 34.37 & 0.09 & $\begin{array}{l}\text { As above, with 2-in-thick bentonite seam, source rock } \\
\text { in the mid oil generation zone. Middld neritic to upper } \\
\text { bathyal (middle shelf to upper slope). }\end{array}$ & 68.5110 & -150.3889 \\
\hline 17 & $02 \mathrm{Mu} 7-39 \mathrm{ft}$ & Cobblestone Creek & KJu & Blankenship Member of Otuk Formation & Possible Oxfordian & $\begin{array}{l}\text { Probable P-M22 } \\
\text { F-16a to } 16 b\end{array}$ & 0.65 & $3.0-3.5$ & 467 & & 32 & 14 & 2.33 & 0.27 & $\begin{array}{l}\text { As above. Middle neritic to upper bathyal (middle shelf } \\
\text { to upper slope). }\end{array}$ & 68.5110 & -150.3889 \\
\hline 17 & $02 \mathrm{Mu} 7-36 \mathrm{ft}$ & Cobblestone Creek & KJu & Blankenship Member of Otuk Formation & Possible Oxfordian & $F-16 a$ to $16 b$ & 0.23 & $2.5-3.0$ & 520 & & 30 & 0 & & 0.41 & $\begin{array}{l}\text { As above. Middle neritic to upper bathyal (middle shelff } \\
\text { to upper slope). }\end{array}$ & 68.5110 & -150.3889 \\
\hline 17 & $02 \mathrm{Mu} 7-33 \mathrm{ft}$ & Cobblestone Creek & KJu & Blankenship Member of Otuk Formation & Possible Oxfordian & $F-16 b ?$ & 4.23 & $3.0-3.5$ & 441 & $\vee ? 0.94$ & 140 & 2 & 55.67 & 0.04 & $\begin{array}{l}\text { Gray bentonitic claystone, more bentonitic than above, } \\
\text { source rock in the mid oil generation zone. Probable } \\
\text { bathyal. }\end{array}$ & 68.5110 & -150.3889 \\
\hline 17 & $02 \mathrm{Mu} 7-30 \mathrm{ft}$. & Cobblestone Creek & KJu & Blankenship Member of Otuk Formation & $\begin{array}{l}\text { Callovian? to Early } \\
\text { Oxtordian }\end{array}$ & $\begin{array}{l}\text { P-M22a } \\
\text { F-16b? }\end{array}$ & 0.76 & $3.0-3.5$ & 475 & & 14 & 13 & 1.10 & 0.39 & $\begin{array}{l}\text { As above, with 6-in-thick bentonite seam at } 29 \mathrm{ftt} \\
\text { Probable bathyal. }\end{array}$ & 68.5110 & -150.3889 \\
\hline 17 & $02 \mathrm{Mu} 7-27 \mathrm{ft}$ & Cobblestone Creek & KJu & Blankenship Member of Otuk Formation & Indeterminate & & 7.28 & $3.0-3.5$ & 442 & $\begin{array}{l}B ? 1.04 \\
V ? ? 1.02\end{array}$ & 201 & 1 & 146.50 & 0.06 & $\begin{array}{l}\text { Black, fissile, laminated, organic-rich paper shale with } \\
\text { thin (<0.5 in thick) bentonitite seams, source rock in the } \\
\text { mid oil generation zone. }\end{array}$ & 68.5110 & -150.3889 \\
\hline 17 & $02 \mathrm{Mu} 7-24 \mathrm{ft}$. & Cobblestone Creek & KJu & Blankenship Member of Otuk Formation & $\begin{array}{l}\text { Probable Early to Middlif } \\
\text { Jurassic, } \\
\text { undifiterentiated }\end{array}$ & & 6.54 & $3.0-3.5$ & 443 & $V ? 0.96$ & 215 & 4 & 56.20 & 0.09 & As above; source rock in the mid oil generation zone. & 68.5110 & -150.3889 \\
\hline 17 & $02 \mathrm{Mu} 7-21 \mathrm{ft}$. & Cobblestone Creek & KJu & Blankenship Member of Otuk Formation & $\begin{array}{l}\text { Possible Jurassic, } \\
\text { undifferentiated }\end{array}$ & & 8.85 & $3.0-3.5$ & 438 & $v ? 1.02$ & 230 & 2 & 135.60 & 0.06 & As above; source rock in the mid oil generation zone. & 68.5110 & -150.3889 \\
\hline 17 & $02 \mathrm{Mu}$ 7-18 ft. & Cobblestone Creek & KJu & Blankenship Member of Otuk Formation & $\begin{array}{l}\text { Possible Jurassic, } \\
\text { undifferentiated }\end{array}$ & & 7.45 & $3.0-3.5$ & 443 & & 184 & 2 & 91.47 & 0.04 & As above; source rock in the mid oil generation zone. & 68.5110 & -150.3889 \\
\hline 17 & $02 \mathrm{Mu} 7-15 \mathrm{ft}$. & Cobblestone Creek & KJu & Blankenship Member of Otuk Formation & $\begin{array}{l}\text { Probable Pliensbachian } \\
\text { to Toarcian }\end{array}$ & Probable F-18a to $18 \mathrm{~b}$ & 7.70 & $3.0-3.5$ & 441 & $\vee ? 0.97$ & 188 & 2 & 96.33 & 0.05 & $\begin{array}{l}\text { As above; source rock in the mid oil generation zone. } \\
\text { Probable bathyal. }\end{array}$ & 68.5110 & -150.3889 \\
\hline 17 & $02 \mathrm{Mu} 7-12 \mathrm{ft}$. & Cobblestone Creek & KJu & Blankenship Member of Otuk Formation & $\begin{array}{l}\text { Probable Pliensbachian } \\
\text { to Toarcian }\end{array}$ & Probable F-18a to $18 \mathrm{~b}$ & 11.23 & $3.0-3.5$ & 437 & $V ? 0.98$ & 224 & 3 & 83.93 & 0.04 & $\begin{array}{l}\text { As above; source rock in the mid oil generation zone. } \\
\text { Probable bathyal. }\end{array}$ & 68.5110 & -150.3889 \\
\hline 17 & $02 \mathrm{Mu} 7-9 \mathrm{ft}$. & Cobblestone Creek & KJu & Blankenship Member of Otuk Formation & $\begin{array}{l}\text { Probabable Early } \\
\text { Jurassic, } \\
\text { undifferentiated }\end{array}$ & Probable F-18a to $18 b$ & 9.05 & $3.0-3.5$ & 439 & $V ? 0.94$ & 245 & 4 & 59.81 & 0.05 & As above; source rock in the mid oil generation zone. & 68.5110 & -150.3889 \\
\hline 17 & $02 \mathrm{Mu} 7-6 \mathrm{ft}$. & Cobblestone Creek & KJu & Blankenship Member of Otuk Formation & $\begin{array}{l}\text { Probable Pliensbachian } \\
\text { to Toarcian }\end{array}$ & Probable F-18a to $18 b$ & 4.93 & $3.0-3.5$ & 445 & & 118 & 2 & 64.55 & 0.05 & $\begin{array}{l}\text { As above; source rock in the mid oil generation zone, } \\
\text { probable bathyal. }\end{array}$ & 68.5110 & -150.3889 \\
\hline 17 & $02 \mathrm{Mu} 7-3 \mathrm{ft}$. & Cobblestone Creek & KJu & Blankenship Member of Otuk Formation & $\begin{array}{l}\text { Probable Pliensbachian } \\
\text { to Toarcian }\end{array}$ & Probable F-18a to $18 b$ & 8.24 & $3.0-3.5$ & 442 & $\vee ? 0.97$ & 199 & 2 & 96.35 & 0.04 & $\begin{array}{l}\text { As above; source rock in the mid oil generation zone, } \\
\text { probable bathyal. }\end{array}$ & 68.5110 & -150.3889 \\
\hline \multirow[t]{2}{*}{17} & $02 \mathrm{Mu} 7-0 \mathrm{ft}$. & Cobblestone Creek & KJu & Blankenship Member of Otuk Formation & $\begin{array}{l}\text { Early Jurassic, } \\
\text { undifferentiated }\end{array}$ & & 6.48 & $3.0-3.5$ & 439 & $\begin{array}{l}\text { B ? } 1.01 \\
V ? 0.94\end{array}$ & 188 & 3 & 96.41 & 0.06 & $\begin{array}{l}\text { As above; source rock in the mild oil generation zone, } \\
\text { probable bathyal. Approximately same horizon as } 01 \\
\text { Mu } 9 \text {. }\end{array}$ & 68.5110 & -150.3889 \\
\hline & & \multicolumn{2}{|c|}{ Southern Cobblestone parautochthonou } & $\begin{array}{l}\text { us sequence } \\
\text { Lower Cretace }\end{array}$ & & & & & & & & & 52133 & & & & \\
\hline 18 & 01 Mu 58 & e creek & Ktol & Torok Formation, lower part & Indeterminate & & 0.72 & $3.0 ?$ & 493 & & 39 & 31 & & 0.30 & & 68.4816 & -150.3642 \\
\hline$\frac{19}{20}$ & $\begin{array}{l}01 \text { Mu } 59 \\
85 \text { Mu } 75\end{array}$ & $\begin{array}{l}\text { ne Creek } \\
\text { Creek }\end{array}$ & $\frac{\mathrm{k} \text { tol }}{\mathrm{K} \text { kol }}$ & $\begin{array}{l}\text { Torok Formation, lower part } \\
\text { Torok Formation lower part }\end{array}$ & $\begin{array}{l}\text { Indeterminate } \\
\text { Necomian? }\end{array}$ & & 0.88 & $3.0 ?$ & $\frac{\sqrt{482}}{482}$ & 11 & 32 & 9 & 0.22 & 020 & Dark gray silty mudstone. & $\begin{array}{l}68.4787 \\
68.4789\end{array}$ & $\begin{array}{l}-150.3596 \\
-150.3731 \\
\end{array}$ \\
\hline 21 & 99 Мu 45 & $\begin{array}{l}\text { Peregrine Creek } \\
\text { Peregrine Creek }\end{array}$ & $\begin{array}{ll}\text { Ktol } \\
\text { Ktol } \\
\end{array}$ & $\begin{array}{l}\text { Torok Formallon, olowerpart } \\
\text { Torok Formation, lower part }\end{array}$ & $\begin{array}{l}\text { Neocomian? } \\
\text { Probable Valanginian }\end{array}$ & & $\begin{array}{l}0.88 \\
1.18\end{array}$ & & 482 & $\frac{1.51}{21.22}$ & 31 & 20.34 & & $\begin{array}{ll}0.20 \\
0.20\end{array}$ & & $\begin{array}{l}68.4789 \\
68.4764\end{array}$ & $\begin{aligned} &-150.3731 \\
&-150.3732 \\
&\end{aligned}$ \\
\hline 21 & $99 \mathrm{Mu} 45-1$ & Peregrine Creek & Ktol & Torok Formation, lower part & $\begin{array}{l}\text { Jurassic-Cretaceoous, } \\
\text { undifferentiated }\end{array}$ & & 0.95 & & 473 & & 26 & \begin{tabular}{|c|}
28.42 \\
\end{tabular} & & 0.17 & & 68.4764 & -150.3732 \\
\hline$\frac{21}{21}$ & $\frac{999445-2}{999 \text { Mu } 45-3}$ & $\begin{array}{l}\text { Peregrine Creek } \\
\text { Peregrine Crekk }\end{array}$ & 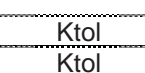 & $\begin{array}{l}\text { Iorok Formation, lower part } \\
\text { Torok Formation, lower part }\end{array}$ & $\begin{array}{l}\text { Indetermir } \\
\text { Probable }\end{array}$ & & $\begin{array}{l}0.46 \\
0.78\end{array}$ & & 475 & $?$ & $\frac{30}{26}$ & $\frac{47.83}{24.36}$ & & $\begin{array}{l}0.13 \\
0.13 \\
0.13\end{array}$ & & $\begin{array}{l}68.4764 \\
68.4764\end{array}$ & $\begin{array}{r}-150.3732 \\
-150.3732 \\
-\frac{1532}{2}\end{array}$ \\
\hline 22 & $01 M 456$ & Peregrine Creek & Ktol & Torok Formation, lower part & Aptian to Albian & $F-99011$ & 0.76 & $3.0 ?$ & 504 & & 37 & 11. & & 0.30 & Black clay shale to silty shale. & 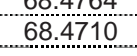 & -150.3729 \\
\hline 22 & $01 \mathrm{Mu} 56-1$ & Peregrine Creek & Ktol & Torok Formation, lower part & $\begin{array}{l}\text { Probable Aptian to } \\
\text { Albian }\end{array}$ & & & 3.0 & & & & & & & Gray silty shale with thin interbedded siltstone. & 68.4710 & -150.3729 \\
\hline 23 & $85 \mathrm{Mu} 75$ & Peregrine Creek & Ktoll & Torok Formation, lower part & & & 0.88 & & 482 & 1.51 & 32 & 9 & 0.22 & 0.20 & & 68.4720 & -150.3710 \\
\hline 24 & $99 \mathrm{MU} 62$ & Nanushuk River & $\mathrm{Kpm}$ & $\begin{array}{l}\text { Torok Formation, manganifierous shale unit; } \\
\text { underlies Cobblestone Member }\end{array}$ & $\begin{array}{l}\text { Possible Aptian to } \\
\text { Albian }\end{array}$ & & & & & & & & & & & 68.4861 & -150.5904 \\
\hline 25 & $99 \mathrm{Mu} 60$ & Nanushuk River & Kfmc & $\begin{array}{l}\text { Cobblestone Member, Fortress Mountain } \\
\text { Formation }\end{array}$ & Indeterminate & & 0.77 & & 481 & 1.4 & 26 & \begin{tabular}{|c|}
41.56 \\
\end{tabular} & & 0.23 & & 68.4601 & -150.5757 \\
\hline 25 & $99 \mathrm{Mu} 60-1$ & Nanushuk River & Kfmc & $\begin{array}{l}\text { Cobblestone Member, Fortress Mountain } \\
\text { Formation }\end{array}$ & Indeterminate & & 0.79 & & 480 & & 20 & 44.30 & & 0.24 & & 68.4601 & -150.5757 \\
\hline
\end{tabular}




\begin{tabular}{|c|c|c|c|c|c|c|c|c|c|c|c|c|c|c|c|c|c|}
\hline $\begin{array}{l}\text { MAP } \\
\text { NO. }\end{array}$ & STATION NO. & LOCATION & $\begin{array}{c}\text { MAP } \\
\text { SYMBOL }\end{array}$ & FORMATION, FIELD DETERMINED & INTEGRATED AGES & $\begin{array}{l}\text { PALEO ZONE } \\
\text { Foram zones-F } \\
\text { Paly zones-P }\end{array}$ & $\begin{array}{l}\text { TOC } \\
\text { Wt } \%\end{array}$ & TAI & \begin{tabular}{|c|c|}
$\begin{array}{c}T_{\max } \\
{ }^{\circ} \mathrm{C}\end{array}$ \\
\end{tabular} & Re & HI & ol & s2/s3 & PI & DISCUSSION & Latitude & Longitude \\
\hline & ALLOCHTHONOU & S ROCKS (arranged in all & hthon struc & ural stacking order from higher to lower) & & & & & & & & & & & & & \\
\hline & & Pinnic Creek or Ipnavik R & er(?) alloch & hons & & & & & & & & & & & & & \\
\hline 26 & 01 Mu 60 & Peregrine Creek & $\mathrm{Kmo}$ & Unnamed mélange/olistostrome & Indeterminate & & 0.66 & 3.02 & 508 & & 33 & 13 & & 0.35 & Sheared mudstone mélange matrix. & 68.4532 & -150.3914 \\
\hline 27 & $00 \mathrm{Mu} 32$ & Cobblestone Creek & Kog & Okpikruak Formation & $\begin{array}{l}\text { Lower Cretaceous } \\
\text { indeterminate }\end{array}$ & & 0.36 & & 517 & V 2.24 & 39 & 53 & 0.74 & 0.36 & & 68.4051 & -150.3143 \\
\hline 28 & $00 \mathrm{Mu} 33$ & Cobblestone Creek & Kog & Okpikruak Formation & $\begin{array}{l}\text { Lower Cretaceous } \\
\text { indeterminate }\end{array}$ & & 0.9 & & 529 & $\mathrm{v} 2.28$ & 26 & 22 & 1.15 & 0.18 & & 68.4354 & -150.2982 \\
\hline $\begin{aligned} 29 \\
.09\end{aligned}$ & $00 \mathrm{Mu} 31$ & May Creek & $\mathrm{kmo}$ & Unnamed mélange/olistostrome & Lower Cretaceous & Indeterminate & 0.79 & & 482 & $v 2.66$ & 25 & 27 & $\begin{array}{l}0.95 \\
\quad 0.92 \\
0.37\end{array}$ & 0.2 & Sheared mudstone mélange matrix. & 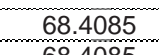 & $\begin{array}{l}-150.1441 \\
\quad 50.141 \\
\end{array}$ \\
\hline & 00 Mu 31-1 & $\begin{array}{l}\text { May Creek } \\
\text { Endicott Mountains alloc }\end{array}$ & Kmo & Unnamed melangefolistostrome & Lower Cretaceous & Indeterminate & 0.53 & & 486 & & & & & 0.23 & Sheared mudstone mélange matrix. & 68.4085 & -150.1441 \\
\hline 30 & $00 \mathrm{Mu} 27-5$ & $\begin{array}{l}\text { May Creek, west fork of } \\
\text { west fork }\end{array}$ & JTro & Blankenship Member of Otuk Formation & Lower Jurassic & Indeterminate & 4.11 & & 540 & $\vee 2.42$ & 3 & 5 & 0.55 & 0.15 & $\begin{array}{l}1 \mathrm{~m} \text { above Karen Creek Sandstone, black organic } \\
\text { shale, contains pelecypodotapiria tailleuri. }\end{array}$ & 68.4075 & -150.2532 \\
\hline 30 & $00 \mathrm{Mu} 27-3.2$ & $\begin{array}{l}\text { May Creek, west fork of } \\
\text { west fork }\end{array}$ & JTro & Otuk Formation & Probable Norian & $F-13 b$ & 0.59 & & 353 & & 5 & 108 & 0.05 & 0.7 & $8 \mathrm{~cm}$ below Karen Creek Sandstone; black clay shale. & 68.4075 & -150.2532 \\
\hline 30 & $00 \mathrm{Mu} 27-3$ & $\begin{array}{l}\text { May Creek, west tork of } \\
\text { west fork }\end{array}$ & JTro & Otuk Formation & Probable Norian & $F-13 b$ & 0.33 & & N.A. & V 2.13 & & 100 & & & $\begin{array}{l}\text { Le comblew Karen Creek Sandstone; green-gray } \\
\text { claystone. }\end{array}$ & 68.4075 & -150.2532 \\
\hline 30 & $00 \mathrm{Mu} 27-2$ & $\begin{array}{l}\text { May Creek, west fork of } \\
\text { west fork }\end{array}$ & JTro & Otuk Formation, limestone member & Upper Triassic & & 1.55 & & 533 & V 2.42 & 12 & 28 & 0.41 & 0.18 & $2 \mathrm{~m}$ below Karen Creek Sandstone. & 68.4075 & -150.2532 \\
\hline 30 & $00 \mathrm{Mu} 27-1$ & $\begin{array}{l}\text { May Creek, west fork of } \\
\text { west fork }\end{array}$ & JTro & Otuk Formation, shale member & Upper Triassic & & 2.88 & & 533 & $\begin{array}{l}B ? 2.52 \\
V ? 2.23 \\
V ? 2.2\end{array}$ & 6 & 28 & 0.20 & 0.39 & Black sooty shale. & 68.4075 & -150.2532 \\
\hline 30 & $00 \mathrm{Mu} 27$ & $\begin{array}{l}\text { May Creek, west fork of } \\
\text { west fork }\end{array}$ & Ps & Siksikpuk Formation & Permian & & 1.21 & & 486 & $\mathrm{v} 2.50$ & 2 & 9 & 0.27 & 0.57 & Near top Ps, weathered gray silty shale. & 68.4075 & -150.2532 \\
\hline & $00 \mathrm{Mu} 29-3$ & Cobbblestone Creek & sTro & Otuk Formation, limestone member & Upper Triassic & & 1.68 & & 540 & & 5 & 111 & 0.44 & 0.43 & & 68.4003 & -150.3186 \\
\hline & $\begin{array}{l}000 \text { Мu 29-2.1 } \\
000 \text { Mu } 29-2\end{array}$ & $\begin{array}{l}\text { Cobbblestone Creek } \\
\text { Cobblestone Creek }\end{array}$ & JTro & $\begin{array}{l}\text { Otuk Kormation limestone member } \\
\text { Ottuk Formation, shale member }\end{array}$ & $\begin{array}{l}\text { Upper Triassic } \\
\text { Indeterminate }\end{array}$ & & $\begin{array}{r}5.00 \\
5.37 \\
\end{array}$ & & $\begin{array}{l}526 \\
537 \\
5\end{array}$ & $\begin{array}{l}\checkmark 3.13 \\
v 3.27 \\
\end{array}$ & $\begin{array}{l}6 \\
4 \\
4\end{array}$ & -3 & $\begin{array}{r}2.29 \\
1.71 \\
\end{array}$ & $\begin{array}{l}0.24 \\
0.25 \\
\end{array}$ & Black limestone & $\begin{aligned} 68.4003 \\
68.4003 \\
\end{aligned}$ & $\begin{array}{l}-150.3186 \\
-150.3186\end{array}$ \\
\hline & 000 Mu 29-1 & Cobblestone Creek & Pss & Sisiksikpuk Formation & Probable Permian & & 0.54 & & 444 & & 13 & $\frac{22}{22}$ & 0.58 & 0.22 & Gray clay shale & 68.4003 & -150.3186 \\
\hline & $\begin{array}{ll}00 M 429 \\
82 M u\end{array}$ & Cobblestone Creek & Ps & 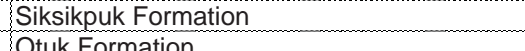 & Probable Permian & & $\frac{0.56}{3.45}$ & & $\begin{array}{ll}\text { N.A. } \\
495\end{array}$ & $\begin{array}{l}v 2.34 \\
2.34 \\
2.34\end{array}$ & & $\frac{73}{4}$ & & & Gray clay shale & $\begin{array}{l}68.4003 \\
63956 \\
630\end{array}$ & -750.3186 \\
\hline & $\begin{array}{l}882 \mathrm{Mu} 71-4 \\
82 \mathrm{Mu} 71-4 \\
10\end{array}$ & $\begin{array}{l}\text { Cobblestone Creek } \\
\text { Cobblestone Creek }\end{array}$ & 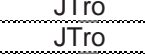 & $\begin{array}{l}\text { Otuk Formation } \\
\text { Otuk Formation }\end{array}$ & $\begin{array}{l}\text { Upper riassic } \\
\text { Upper Triassic }\end{array}$ & & $\frac{3.45}{3.45}$ & & $\frac{495}{495}$ & $\begin{array}{l}2.34 \\
? 2.34 \\
? 2.34\end{array}$ & 8 & $\frac{4}{4}$ & $\begin{array}{l}0.18 \\
0.18\end{array}$ & 0.88 & & 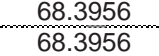 & $\begin{array}{l}-150.3170 \\
-150.3170 \\
\end{array}$ \\
\hline & $82 M u 71-1$ & Cobblestone Creek & Ps & Siksikpuk Formation & Permian & & 0.79 & & 457 & 2.56 & $\frac{9}{9}$ & 33 & 0.27 & 0 & Gray clay shale & 6.68 .3942 & -150.31811 \\
\hline & References: & & & & & & & & 烈 & & & 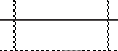 & 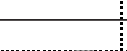 & & & & \\
\hline & Micropaleo Consult & ants, Inc., Biostratigrt & oort of 140 & crop Samples from North Slope, Alaska, June & 24, 1994, June 24, 1994 & & & & & & & & & & & & \\
\hline & $\begin{array}{l}\text { Micropalalo Consultit } \\
\text { Micropaleo Consiltt }\end{array}$ & 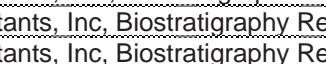 & $\begin{array}{l}\text { lot } 37 \text { Outer } \\
\text { ort for } 1410\end{array}$ & 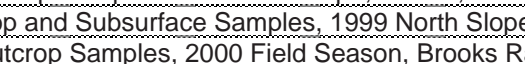 & $\begin{array}{l}\text { Field Party. March 14, } 20 \\
\text { ange Foothilis and Norths }\end{array}$ & Selo: & 001 & & & & & & & & & & \\
\hline & Micropaleo Consult & ants, Inc, Biosstratigraphy Re & ort, 74 Outore & pamples, 2001 North Slope Field Party, Bro & oks Range, Alaska, Janu & ary 28,20022 & & & & & & & & & & & \\
\hline & Micropaleo Consult & tants, Inc, Biostratigraphy Re & ort 33 Outer & p Samples, 2000 \& 2002 North Slope Field P P & arties, Brooks Range, Alas & Sska, Brooks Range, Ailo & a. Januar & $y 30,200$ & 03 & & & & & & & & \\
\hline & TOC - total organic & carbon & & TOC $-<0.5$-nonsource & $\mathrm{T}_{\text {Max }}<435$ - immature & & $\overline{R_{0}<0.6-}$ & immature & & & s2/S3. & $<2.5-\mathrm{gas}$ & s prone & & $\mathrm{HI}=\mathrm{S} 2 / \mathrm{TOC} \times 100 \quad \mathrm{Ol}=\mathrm{S} 3 / \mathrm{TOC} \times 100$ & & \\
\hline & TAI -thermal altera & tion index & & $0.5-1.0$ - fair source rock & $435-460$ - mature & & 0.6 to & $1.2-\mathrm{ma}$ & nature & & & 2.5 to $5-$ & -oil and ga: & is prone & $\mathrm{HI}>\sim 400$ - Type 1 kerogen, algal & & \\
\hline & $T_{\max }-$ maximum tel & mperature & & 1.0-2.0-good source rock & $>460$ - overmature & & $>2.0-$ & overmatu & ture for & wet gas & & 5 - oil pre & & & HI 200-400 - Type II kerogen, marine & & \\
\hline & $\mathrm{R}_{\mathrm{o}}-$ Vitrinite reflect & & & 2.0-4.0 - very good source rock & Micropaleontology by I & Micropaleo Consultants, & $3.7-$ & dry gas li & limitit & & & & & & HI < 200-Type Ill kerogen, terrestrial & & \\
\hline & H-Hydrogen inde & & & $>4.0$ - excellent source rock & & & & & & & & & & & & & \\
\hline & $\begin{array}{l}\text { OI-Oxygen index } \\
\text { S2/S3-chromatog }\end{array}$ & & & & & & & & & & & & & & & & \\
\hline & $\mathrm{PI}-\mathrm{Pet}$ & & & & & & & & & & & & & & & & \\
\hline
\end{tabular}




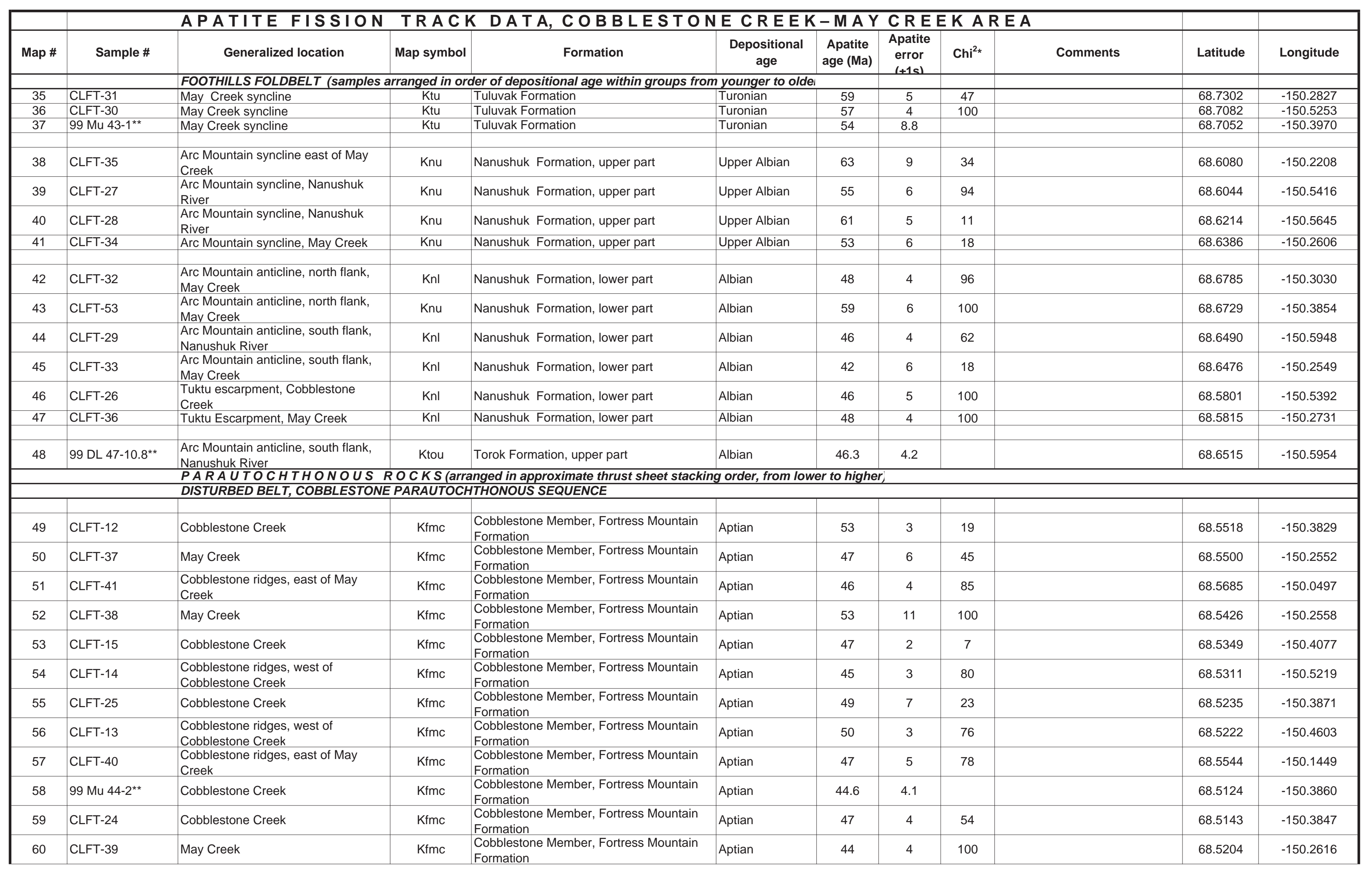




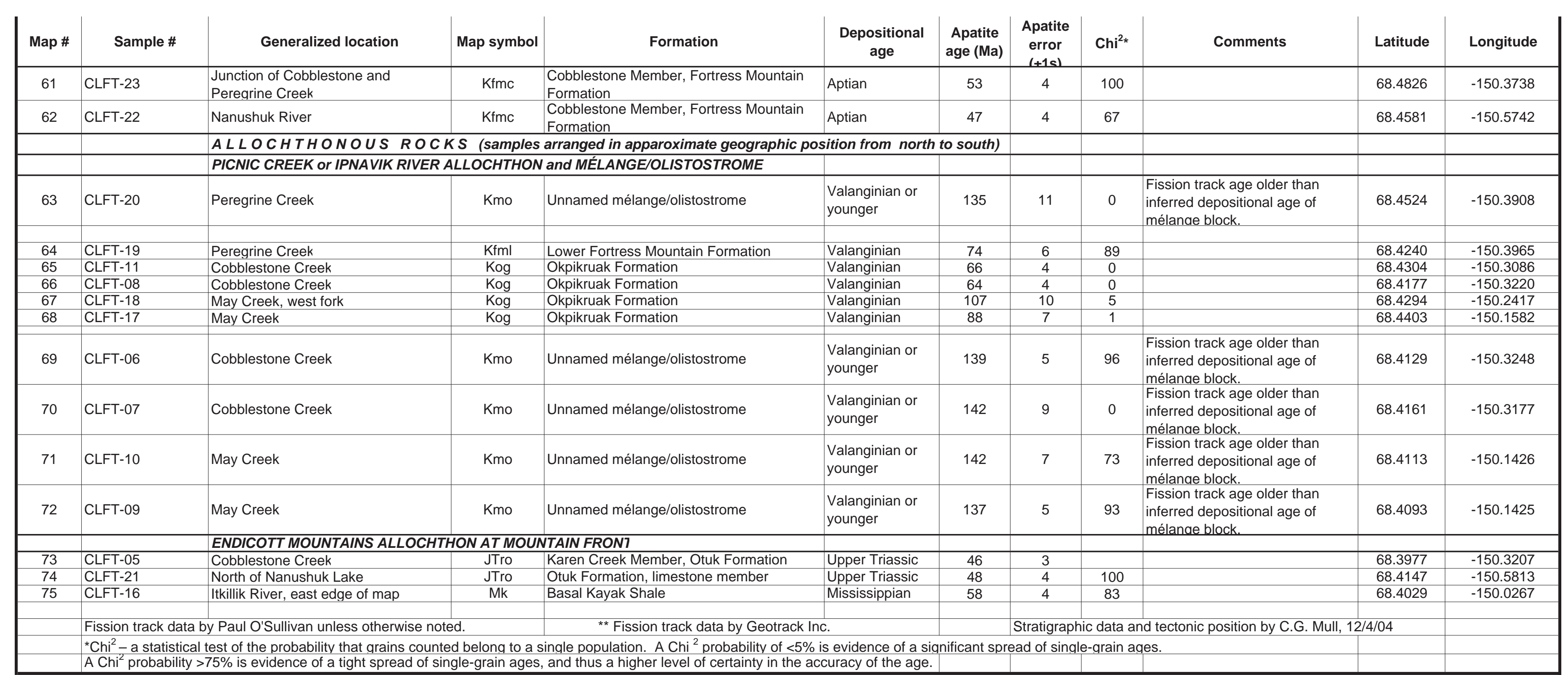

